BUDAPESTI CORVINUS EGYETEM

\title{
ANOMÁLIÁK A RÉSZVÉNYPIACI ÉS ALAPKEZELÖI JELENTÉSEK KÖRÜL
}

\author{
DOKTORI ÉRTEKEZÉS
}

Témavezető: Dr. Csóka Péter és Dr. Pintér Miklós

Rácz Dávid Andor

Budapest, 2019. 

Rácz Dávid Andor

\section{ANOMÁLIÁK A RÉSZVÉNYPIACI ÉS ALAPKEZELŐI} JELENTÉSEK KÖRÜL 
Befektetések és Vállalati Pénzügy Tanszék

Témavezető: Dr. Csóka Péter és Dr. Pintér Miklós

(C) Copyright - Rácz Dávid Andor 2019 


\author{
BUDAPEST CORVINUS EGYETEM \\ GAZDÁLKODÁSTANI DOKTORI ISKOLA
}

\title{
ANOMÁLIÁK A RÉSZVÉNYPIACI ÉS AZ ALAPKEZELÖI JELENTÉSEK KÖRÜL
}

\author{
DOKTORI ÉRTEKEZÉS
}

Rácz Dávid Andor

Budapest, 2019. 



\section{TARTALOM}

1. IRODALMI ÉS MÓDSZERTANI ÖSSZEFOGLALÓ ............................ 12

1.1. PIACI HATÉKONYSÁG ELMÉLETE ÉS KRITIKÁI ................ 18

1.1.1. A hatékony piacok elmélete és a részvényárak véletlen bolyongása 19

1.1.2. A hatékony piacok kritikái, a közepesen erős hatékonyság tesztjei 20

1.1.3. Az anomáliák viselkedési közgazdaságtani háttere 21

1.1.4. Piaci hatékonyság és az arbitrázshozamok megléte...................22

1.2. AZ ESEMÉNYELEMZÉS MÓDSZERTANA .............................2 25

1.2.1. A várható hozamok modellezése...........................................26

1.2.2. Az eseményablak és a becslési ablak hossza .............................2 27

1.2.3. Az abnormális hozamok mérése és tesztelése ............................29

1.3. A BEFEKTETÉSI ALAPOK TELJESÍTMÉNY-

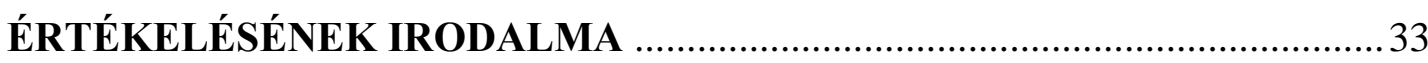

1.3.1. Az abszolút hozamú befektetési alapok definíciója ...................36

1.3.2. Klasszikus teljesítményértékelő mutatószámok ..........................37

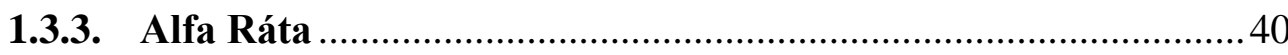

1.3.4. Manipulációbiztos Teljesítménymutatók..................................46

1.3.5. A manipulált teljesítmény feltárása az MBTM-ek segítségével. 53

1.3.6. A manipulált teljesítmény, hozamsimítás feltárásának alternatív módjai: Torzítási Ráta, Diszkontinuitás-elemzés............................................60

2. SAJÁT SZÁMÍTÁSI EREDMÉNYEK 64

2.1. NEGYEDÉVES JELENTÉSEK MEGLEPETÉS-HATÁSÁNAK ELEMZÉSE AZ S\&P 500 RÉSZVÉNYEI ESETÉN .........................................66

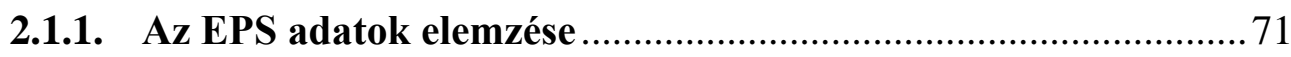

2.1.2. Paraméterbecslés és a hozamok modellezése ........................... 73 
2.1.3. Az abnormális hozamok számítása és aggregálása .74

2.1.4. Árfolyam-reakciók a negyedéves jelentések hatására ............... 79

2.1.5. Különbözőségek az EPS meglepetés hatásában .86

2.2. A MAGYAR ABSZOLÚT HOZAMÚ BEFEKTETÉSI ALAPOK HOZAMAINAK ELEMZÉSE AZ MBTM-EK SEGÍTSÉGÉVEL, ÉS A HOZAMMANIPULÁCIÓ NYOMAINAK KIMUTATÁSA .89

2.2.1. Az elemzés elvégzéséhez szükséges elemek kezelése .90

2.2.2. A Sharpe-ráta és az Ingersoll et al. (2007)-féle MBTM rangsorolásának összevetése .94

2.2.3. A hozammanipuláció, hozamsimítás nyomainak kimutatása különböző módszerekkel .98

2.2.4. Az MBTM és a Kételkedési Hányados Ingersoll et al. (2007) - és Brown et al. (2010)-féle értékeinek és rangsorolásának összevetése 117

2.2.5. Az Ingersoll et al. (2007) - és Brown et al. (2010)-féle számítási módszer összevetése a gyakorlati használhatóság és a kivitelezés összetettsége alapján, javaslat az alkalmazandó módszerre

3. ÖSSZEFOGLALÓ 125

IRODALOMJEGYZÉK 130

A TÉMAKÖRREL KAPCSOLATOS SAJÁT PUBLIKÁCIÓK JEGYZÉKE 138 


\section{ÁBRÁK JEGYZÉKE}

1. ábra: Egy eseményelemzés időrendje (MacKinlay, 1997, p. 20). 28

2. ábra: Az S\&P 500 és az S\&P 500 IT indexeiből vett megfigyelések esetén mutatkozó EPS meglepetés gyakoriságának eloszlása. .72

3. ábra: Az öt csoport kumulatív átlagos abnormális hozamai az esemény körüli időszakban a két részvényindexből vett minta esetén nagyon jó, jó, semleges, rossz és nagyon rossz hírek csoportjának esetén. .78

4. ábra: A Sharpe-ráta és az MBTM rangsorolásának összehasonlítása különböző kockázat-elutasítási együtthatók mellett. 95

5. ábra: A legmagasabb Kételkedési Hányadossal rendelkező alapok elemzése.. 100 6. ábra: A Torzítási Ráta értékeinek megoszlása a vizsgált befektetési alapok esetében. 101

7. ábra: A Torzítási Ráta és a Kételkedési Hányados értékeinek összehasonlítása. 103

8. ábra: A Citadella Származtatott alap hozamainak 0-körüli diszkontinuitáselemzése. 106

9. ábra: Az Aegon Ózonmaxx alap hozamainak 0-körüli diszkontinuitáselemzése. 108

10. ábra: A Platina Béta alap hozamainak 0-körüli diszkontinuitás-elemzése. ... 110 11. ábra: Az Erste DPM alap hozamainak 0-körüli diszkontinuitás-elemzése. ... 111 


\section{TÁBLÁZATOK JEGYZÉKE}

1. táblázat: Alfa és Béta hozamok két devizabefektető esetében Pojarliev és Levich, 2013100 . oldala alapján.

2. táblázat: Az egyes devizabefektetők teljesítménye 2001-2006 Pojarliev és Levich (2008) 25. oldal alapján. Saját szerkesztésben félkövéren szedéssel kiemelve azok az esetek, ahol az Információs Ráta pozitív értékből negatívba vált a béta hozamokkal korrigált Alfa Ráta számításakor. .46

3. táblázat: A manipulációbiztos teljesítménymutató Ingersoll et al. (2007) 1532. oldal alapján.

4. táblázat: Rangkorrelációk a klasszikus és a manipulációbiztos teljesítménymutatók között (az eredeti hozamokon tesztelve) Brown et al. (2010) 49. oldal alapján.

5. táblázat: Rangkorrelációk a klasszikus és a manipulációbiztos teljesítménymutatók között (a replikált hozamokon tesztelve) Brown et al. (2010) 50. oldal alapján. .55

6. táblázat: Rangkorreláció a Sharpe-ráta és az MBTM között befektetésistílus szerinti csoportosításban Brown et al. (2010) 56. oldal alapján.. .56

7. táblázat: A Kételkedési Hányadosok összehasonítása az alternatív módszerek szerinti manipuláltság alapján csoportosítva Brown et al. (2010) 57. oldal alapján.

8. táblázat: Az extrém magas Kételkedési Hányadossal rendelkező alapok Brown et al. (2010) 58. oldal alapján.

9. táblázat: Az S\&P500 és S\&P 500 IT legnagyobb piaci kpitalizációjú elemzett részvényei, amelyre rendelkeztünk a szükséges adatokkal .70

10. táblázat: Az öt meglepetéskategória átlagos és kumulatív átlagos abnormális hozamai az esemény körüli időszakban a két részvényindexből vett minta esetén. 75

11. táblázat: Az S\&P 500 indexből vett minta kumulatív átlagos abnormális hozamai és ezen hozamok szórásai, tesztstatisztikák, kritikus értékek és p-értékek az öt hírcsoport, és különböző időintervallumok esetén. .82 
12. táblázat: Az S\&P 500 IT indexből vett minta kumulatív átlagos abnormális hozamai és ezen hozamok szórásai, tesztstatisztikák, kritikus értékek és $p$-értékek az öt hírcsoport, és különböző időintervallumok esetén.

13. táblázat: Az S\&P 500 és az S\&P 500 IT indexből vett minták kumulatív átlagos abnormális hozamai közötti eltérés t-statisztikái az öt hírcsoport esetén a $(-10,10)$ intervallumon.

14. táblázat: A kiválasztott abszolút hozamú alapok. 91

15. táblázat: Rangkorrelációk a Sharpe-ráta és az MBTM között különböző kockázatelutasítási együtthatókra.

16. táblázat: Az MBTM alapján legjobbnak és legrosszabbnak rangsorolt alapok tulajdonságai. .97

17. táblázat: A legmagasabb Kételkedési Hányadossal rendelkező alapok tulajdonságai. 99

18. táblázat: Az Ingersoll et al. (2007)- és a Brown et al. (2010)-féle MBTM értékeinek és rangsorolásának összevetése. 120

19. táblázat: Kételkedési Hányados értékeinek összehasonlítása Ingersoll et al. (2007) és Brown et al. (2010)-alapú MBTM értékekből számítva, valamint a Brown et al. (2010)-féle közelítést használva. 


\section{Köszönetnyilvánítás}

Köszönöm konzulenseimnek, Csóka Péternek és Pintér Miklósnak, hogy értékes visszajelzéseik és iránymutatásaik mellett mindig megadták nekem a szükséges lendületet és bíztatást ahhoz, hogy végig járjam az értekezés megszületéséhez szükséges út lépéseit. Köszönöm Berlinger Edinának, hogy támogatta a disszertációm elkészültét. Köszönettel tartozom Király Júliának, hogy elindított a doktori képzés irányába, mert a bíztatása nélkül nem biztos, hogy jelentkeztem volna a képzésre.

Köszönetet mondok a szerzőtársamnak Huszár Gergelynek az együtt írt publikációnkért, amely a disszertációban elemzett egyik témakör magját képezte. Köszönöm jóbarátom, Kocsi János segítségét az elemzési részhez szükséges adatok letöltésében.

Köszönöm Richard Wattnak, Glenn Boyle-nak és Philip Meguire-nek, hogy az új-zélandi vendégkutatásom alatt kedvesen fogadtak és hasznos tanácsokkal láttak el a disszertációm megírásához. Köszönettel tartozom Stephen Tonniesnak, aki új-zélandi tartózkodásomon nem csak szálláshelyet biztosított, de családtagként segített elboldogulni a hétköznapi kihívások közepette távolról jött látogatóként.

A családomnak köszönöm a türelmét és a hátteret, amit biztosítottak ahhoz, hogy ez az értekezés elkészülhessen. A disszertációt édesanyám emlékének is ajánlom, aki bár nagyon szerette volna látni az elkészültét, ezt sajnos a földi síkon már nem tehette meg, de biztos vagyok benne, hogy most örömmel nézi fentröl a végeredményt.

Hálás vagyok, hogy volt lehetőségem, hátterem, és időm befejezni ezt az értekezést, ami nem jöhetett volna létre, ha mindezeken felül nem ad kitartást és energiát is hozzá az, Aki mindennek a forrása. 
„Aki nem számol, az nem számít." Prékopa András 


\section{IRODALMI ÉS MÓDSZERTANI ÖSSZEFOGLALÓ}

A pénzügyi piacokon számos rendellenességgel, piaci kudarccal találkozhatunk. Ezekből kettőt elemzünk az értekezésben, amelyeket az a logikai kapocs köt össze, hogy mindkettő megismerése és megfelelő kezelése által a befektetők elkerülhetik a hatékonytalanságokat, amelyek csökkentik a befektetők hasznosságát mivel azok szuboptimális döntésekhez, elmaradt haszonhoz, vagy elkerülhető veszteségekhez, és végeredményben nagymértékü társadalmi károkhoz vezetnek.

$\mathrm{Az}$ egyik elemzett anomália a tőzsdén jegyzett vállalatok negyedéves tőzsdei jelentéseinek időszaka körül a piac hatékonyságának kérdése, amit az abnormális hozamoknak a jelenléte által lehet elemezni. Ezen árazási anomália azért bír jelentőséggel a befektető számára, mert ha a tőzsdei jelentéseket megelőző, valamint követő időszakban az abnormális hozamok jellemző tendenciákat mutatnak a félreárazódásokról, akkor a befektető saját hasznosságának növelése céljából szeretné kiismerni ezeket, hogy a meglévő arbitrázsszerű lehetőségek lekereskedése által többlethozamra tehessen szert a jövőben, amely által a félreárazódás megszünne és a piaci árazás visszatérne a valós és hatékony értékeltségéhez. Csak az S\&P 500 indexet alkotó tőzsdei vállalatok összesített piaci kapitalizációja mintegy 22 billió amerikai dollár ${ }^{1}$, így az ezen piaci kudarc által potenciálisan érintett vagyon is hatalmas méretü világszerte.

A piaci hatékonyság szakirodalomának áttekintése, valamint az eseményelemzés módszertanának bemutatása után arra a kérdésre keressük majd a választ a saját számításainkat összefoglaló 2.1. fejezetben, hogy (1) az S\&P500 index részvényeinek negyedéves jelentéseiben az EPS-meglepetések iránya és nagysága meghatározza-e az árfolyam-reakciókat, és az abnormális hozamok milyen intervallum alatt jelentkeznek. További kérdés, hogy vajon (2) a technológiai szektorban tevékenykedő és bizonytalanabb értékeltséggel bíró tőzsdei vállalatok esetében a nagyobb bizonytalanságból fakadóan tapasztalható abnormális árfolyamreakciók felülmúlják-e az általános részvénypiachoz tartozó vállalatok esetében tapasztalt reakciókat.

\footnotetext{
${ }^{1}$ http://siblisresearch.com/data/total-market-cap-sp-500/
} 
Az eredményeink szerint a vállalatok profitabilitásában jelentkező meglepetés iránya és nagysága határozza meg azt, hogy hogyan módosulnak a részvényárfolyamok a bejelentés hatására. Ugyanakkor eltolódás figyelhető meg az egyes hírcsoportok esetén érzékelt kumulált abnormális hozamok szintjében és irányában a negatív ár-reakciók irányába, mivel szignifikáns pozitív hozam csak a nagyon jó hírek csoportjában jelentkezik. Az új információ hatása a bejelentést követő kereskedési napokon már nem figyelhető meg és nem alakul ki a meglepetés irányának megfelelő trend. Így az elemzés azt támasztja alá, hogy a kiválasztott mintában lévő részvények piaca közepesen hatékony. Általánosan szignifikánsan nagyobb árfolyamreakciók mutatkoznak az S\&P500 IT index hírcsoportjaiban az S\&P 500 indexhez viszonyítva.

A disszertációban elemzett másik anomália a befektetési alapok teljesítményének értékelésekor, a teljesítménymérő mutatószámokban tapasztalható manipuláció, amellyel a befektetési alapkezelők tényleges hozzáadott érték nélkül javíthatják fel a kimutatott teljesítményüket, hogy ezáltal több befektetőt és tőkét tudjanak magukhoz vonzani. Meg kell ugyanakkor jegyezni, hogy a szakirodalomban teljesítménymanipulálásnak nevezett tevékenység az esetek túlnyomó többségében nem illegális cselekedet vagy csalás, hanem „csak” félrevezető tevékenység. Ennek során a befektetési alapkezelő tudatosan vagy tudattalanul olyan befektetési tevékenységet folytat, ami csak a klasszikus teljesítménymutatók értékét (és közvetve a saját jutalékát) növeli, de a racionális befektető hasznosságát nem (bár a viselkedési torzításban szenvedő megtévesztett befektető örülhet neki), így az szuboptimális befektetési döntéseket jelent. Ingersoll et al. (2007) megmutatták, hogy létezhetnek olyan jól megkonstruált teljesítménymutatók, melyek hasznossági alapú megközelítésből indulva képesek kiküszöbölni a klasszikus teljesítménymutatók manipulálhatóságából eredő problémákat. Értéküket csak olyan befektetési döntésekkel lehet növelni, ahol az alapkezelő menedzser a piachoz viszonyítva többletinformációval rendelkezik, vagy képes valós hozzáadott értéket létrehozni az időzítési, kiválasztási képességének birtokában.

A teljesítménymanipulálásnak alapvetően két fajtája létezik: Az egyik a hozamsimítás, amikor illikvid vagy nehezen értékelhető eszközök kreatív kimutatása által az alapkezelő megpróbálja kisimítani az esetleges veszteséges időszakokat, és így mesterségesen 
csökkenti a szórást és ezáltal növeli a kimutatott kockázattal korrigált teljesítményét. Ez a fajta tevékenység a magyar piacon gyakorlatilag kizárható, mivel elkülönült és független letétkezelő értékeli és publikálja általában napi rendszerességgel az alapok egy befektetési jegyre jutó nettó eszközértékét. A másik módszer a dinamikus manipuláció témakörébe tartozik, amikor a befektetési alapkezelő a befektetési stratégiáját a közelmúltbeli teljesítményétől és nem pusztán a piaci helyzet racionális elemzésétől teszi függővé. Például azért menekül kockázatmentes hozamba az év hátralévő részére, hogy megvédje az év első részében már elért többlethozamát a benchmarkhoz viszonyítva. Ám ezzel a tevékenységgel az a probléma, hogy szuboptimális befektetési döntésekhez vezethet, amik ugyan védik, vagy javítják a kimutatott teljesítményt, mégis kárt okoznak a befektetőknek, mert nem növelik a befektetői hasznosságot és a túlzott kockázatkerülés miatt ígéretes befektetési lehetőségeket szalasztanak el.

A teljesítménymanipulálásból fakadó piaci kudarc is komoly, társadalmi méretü károkat képes okozni, mivel a manipulált hozamokon és teljesítménymutatókon alapuló befektetési döntések szuboptimálisak lesznek, azaz nem azokba a befektetési alapokba fogják allokálni a tőkét a befektetői piac szereplői, ahová akkor fektetnének be, ha nem a manipulált és félrevezethető klasszikus mutatószámok alapján, hanem a valós teljesítmény ismeretében fektetnének be. Így végeredményben nem azokba a vállalatokba áramlik a tőke a befektetési alapokon keresztül, amelyek a leghatékonyabb, legnagyobb hozzáadott értéket előállító beruházásokat tudták volna végrehajtani a beáramló forrásokból, így társadalmi szinten is jelentkezik az elmaradt haszon, és maradnak el értékes beruházások. A társadalmi hasznosság további kutatási területe a környezetileg, társadalmilag, és a vállalatirányítási szempontból nagy hasznossággal bíró alapok (ESG - Environmental, Social, Governance) elemzésével foglalkozik (Az energiahatékonysági befektetések pénzügyi megtérülésének kérdésköréről lásd Rácz (2012)). Az aktívan menedzselt befektetési alapok kezelésében csak az Egyesült Államokban hozzávetőleg 16 billió dollárnyi vagyon található ${ }^{2}$.

A piaci hatékonytalanság ott is jelentkezik, hogy ha a hozammanipulációt nem sikerül kiszürni a teljesítményértékelésben, akkor nem azok a befektetési alapkezelők lesznek

\footnotetext{
${ }^{2}$ https://seekingalpha.com/article/4213088-lipper-u-s-mutual-funds-etps-q3-2018-snapshot
} 
megfelelően premizálva, akik valós hozzáadott értéket képesek előállítani, hanem azok a szereplők, akik sikeresek a teljesítménymanipulálásban.

A szakirodalmi összefoglalóban áttekintjük a befektetési alapok teljesítményértékelésének a fejlődését, majd áttérünk a Manipulációbiztos Teljesítménymutatók (MBTM-ek) bemutatására. Kitérünk az MBTM-re épülő Kételkedési Hányadosra mint manipulációjelző mutatószámra, valamint a hozammanipuláció kimutatásának alternatív módjaira, a Torzítási Rátára és a Diszkontinuitás-elemzésre. A saját számításainkat tartalmazó 2.2. fejezetben a magyarországi abszolút hozamú alapok adatain végzett elemzésünkben a hozammanipuláció vagy szuboptimális befektetési döntések nyomait keressük, ami új eredmény, mivel még nem ismert példa a hozammanipuláció nyomainak kimutatására a szakirodalomban magyar befektetési alapok esetén.

A végzett számításaink szerint a rangkorrelációk az MBTM és a Sharpe-ráta között a 0,76 - 0,82 tartományba esnek, ami jelez valamilyen szintü hozammanipulációt vagy hozamsimítást. Új eredményként megállapítjuk, hogy szemben a szakirodalom szerinti várakozással az MBTM-nek a Brown et al. (2010)-féle lineáris közelítése kevésbé bünteti a kockázatot az Ingersoll et al. (2007)-féle számításhoz viszonyítva és ezért az néha sorrendet is befolyásoló módon pontatlan az eredeti Ingersoll et al. (2007)-féle képlethez viszonyítva. Ezért új megállapításként az MBTM számítását az Ingersoll et al. (2007) szerinti módszerrel ajánljuk végezni.

További új eredményünk, hogy saját számításaink szerint bár a Kételkedési Hányadost Brown et al (2010) építette fel, mégis az Ingersoll et al. (2007)-féle MBTM-re épülő verzióját érdemes használni, mivel általa pontosabb eredményeket kapunk, hiszen az MBTM-ben jelentkező pontatlanságok általában felnagyítva öröklődnek tovább a Kételkedési Hányadosba.

Saját számításainknak további, a szakirodalomhoz hozzájáruló új eredménye az is, hogy a Kételkedési Hányadosnak a szakirodalomban megfigyelt, az alternatív hozammanipulációt kimutató módszerekkel való szoros átfedésével (Brown et al. (2010) alapján 80\%-os egyezés) szemben az elemzett mintánkon felemás 
eredményeink születtek: Az alternatív módszerek a 31 befektetési alapból 10 esetben jeleztek nagy valószínűséggel anomáliát, azaz hozammanipulációt vagy szuboptimális befektetési döntéseket, míg a Kételkedési Hányados csak 4 befektetési alapot jelölt meg. Előbbi esetén a Diszkontinuitás-elemzés általi megerősítést a 10-ből 4 esetben találunk, míg a Kételkedési Hányados esetén 4-ből 1 ugyanez az arány. Összességében tehát az eredményeink szerint a Torzítási Ráta jobb előszürő eszköznek bizonyult a hozammanipuláció részletesebb elemzéséhez (pl. Diszkontinuitás-elemzéssel), mint a Kételkedési Hányados. A befektetési politikák, valamint a befektetési alapkezelökkel folytatott interjúink alapján ugyanakkor csak egy alap, a Concorde Citadella alap esetében lehetett megalapozottnak tekinteni az akár több módszer által adott párhuzamos gyanús jelzéseket a hozammanipulációra vagy szuboptimális befektetési döntésekre, és ezen alapot mind a Kételkedési Hányados, mind a Torzítási Ráta is gyanúsnak jelölte. Ezen alap esetében megalapozottnak tünik az időnként szuboptimális befektetési döntések miatti torzítás megléte a befektetési politika ismeretében.

Új megközelítést alkalmaztunk akkor is, amikor a csoportátlagtól vett kirívó eltérések grafikus ábrázolásának segítségével különítettük el a gyanús befektetési alapokat, mind a Kételkedési Hányados, mind a Torzítási Ráta esetében. Saját számításaink birtokában az alábbi új protokollt javasoljuk a teljesítménymanipulálás vagy szuboptimális befektetési döntések kiszürésére: 1. A 150-nél nagyobb Kételkedési Hányadossal bíró befektetési alapok Diszkontinuitás-elemzése, valamint a Torzítási Rátájának figyelembevétele a gyanú megerősítéséhez. 2. A Torzítási Ráta és a Kételkedési Hányados értékeinek grafikus ábrázolása a Torzítási Ráta-Kételkedési Hányados térben, majd a csoportátlagtól való eltérés alapján a szélsőségesnek tünő befektetési alapok hozamainak Diszkontinuitás-elemzése. 3. A mediánnál nagyobb Torzítási Rátával rendelkező befektetési alapok Diszkontinuitás-elemzése. 4. A befektetési politikák áttekintése a mögöttes befektetési döntések megértésére, amelyek megerősíthetik vagy cáfolhatják a szuboptimális döntések potenciális meglétét, illetve gyengíthetik a statisztikai módszerek megbízhatóságát, ha például kötvénytúlsúlyos a befektetési alap összetétele, vagy ha az alap alapok alapjaként müködik és mindig befektetési alapokba allokálja a tőkéjének a nagy részét. 
A disszertáció szerkezete a következő: Az 1. fejezetben található az irodalmi és módszertani összefoglaló, amelyen belül az 1.1. fejezetben a piaci hatékonyság elméleteit és kritikáit foglaljuk össze elsőként. Ezt követően az 1.2. fejezetben az eseményelemzés módszertanát mutatjuk be. Az 1.3. fejezetben a befektetési alapok teljesítményértékelésének fejlődését, valamint a manipulációbiztos mutatószámokat és a teljesítménymanipuláció kimutatásának módszereit prezentáljuk. A 2. fejezetben rátérünk saját eredményeink tárgyalására, így a 2.1. fejezetben a negyedéves jelentések árfolyamhatását elemezzük, hipotézisvizsgálatot végezve a piaci hatékonyság tesztelésére, valamint arra vonatkozóan, hogy van-e érdemi különbség az abnormális hozamok mértékében az S\&P500 és S\&P500 IT index esetében. A 2.2. fejezetben ezt követően a magyar abszolút hozamú alapok esetén keressük a teljesítménymanipuláció vagy szuboptimális befektetési döntések nyomait a klasszikus mutatószámok rangsorát összevetve az MBTM sorrendjével, továbbá a Kételkedési Hányados és más alternatív manipulációjelző módszerek segítségével. A 3. fejezetben az eredményeink összefoglalásával zárjuk a disszertációt. 


\subsection{PIACI HATÉKONYSÁG ELMÉLETE ÉS KRITIKÁI}

Ez a fejezet a piaci hatékonyság szakirodalmát foglalja össze és a benne tárgyaltak a Rácz és Huszár (2018) kéziratcikkünkre, illetve a Rácz és Huszár (2019, pp. 244-246.) cikkünkben leírtakra épülnek. Egy pénzügyi termék piacán létrejövő egyensúlyi árra tekinthetünk úgy, mint a piaci szereplök összesített véleményére a termék értékét illetően az adott pillanatban rendelkezésükre álló összes információ alapján. A piaci árak a szereplők által birtokolt információk és az ezekről alkotott kép alapján mozognak; minden új hír, információ, amely megváltoztatja egy adott termék piac által észlelt értékét, hatással van a keresletre és a kínálatra, ezáltal a termék egyensúlyi árára is.

Az információ hatása az árakra leglátványosabban talán a tőzsdéken figyelhető meg. A tőzsdén jegyzett vállalatoknak szigorú közzétételi elöírásoknak kell megfelelniük, emiatt jóval inkább jellemző rájuk a transzparencia, mint más cégekre. A jó megfigyelhetőségnek köszönhetően széles az irodalma az új információk részvényárakra gyakorolt hatásának. Egyfajta mérföldkőnek tekinthetők a témakörben Ball és Brown (1968), valamint Fama et al. (1969) tanulmányai, amelyek bemutatták az eseményelemzésnek (event study) alapjaiban azóta is változatlan módszertanát (MacKinlay, 1997).

Az említett korai tanulmányok fó célja az volt, hogy empirikus igazolást biztosítsanak a hatékony piaci hipotézishez, miszerint a részvényárak mindig teljes mértékben tükrözik a rendelkezésre álló információkat (Fama, 1970). Ezek az eredmények - és még sok más kutató munkája - alátámasztották a feltételezést, amelynek következtében a hatékony piacok elmélete szerves, meghatározó részévé vált a pénzügyi gondolkozásnak. Idővel azonban számos kritikus hang is megjelent a szakirodalomban, amelyek többnyire a viselkedési pénzügy (behavioral finance) képviselőitől érkeztek. Ezen elmélet szerint figyelembe kell venni a befektetői pszichológiát és kognitív torzításokat (cognitive biases). Tanulmányok széles köre mutatja be a befektetői pszichológia és az eszközárak kapcsolatát empirikusan, amelyek gyengítik a hatékony piaci hipotézis érvényességét (lásd Hirshleifer (2001), Barberis és Thaler (2003)). 


\subsubsection{A hatékony piacok elmélete és a részvényárak véletlen bolyongása}

Ez az alfejezet a hatékony piacok elméletének szakirodalmát foglalja össze. Bármilyen értékpapír értéke megegyezik a jövőbeli pénzáramlásainak jelenértékével, egy tökéletes világban pedig ez lesz az egyensúlyi ár is. Részvények esetében ez nem más, mint a jövőbeli osztalékok jelenértéke (az osztalékok alakulásáról, valamint a részvények árazásáról lásd például Havran et al. (2015)). Mivel nincsenek biztos ismereteink arról, hogy miképp alakulnak ezek a pénzáramlások, így az árfolyam a befektetők várakozásait tükrözi. Különböző piaci vagy egyedi sokkok hatására azonban megváltoznak a vállalat fundamentumai és jövedelemtermelő képessége, ezáltal értékeltsége is. Ezt a folyamatot írja le a hatékony piacok elmélete.

Hatékonynak nevezünk egy piacot akkor, ha az árak mindig teljes mértékben tükrözik a rendelkezésre álló információkat (Fama, 1970). A részvényárfolyamok véletlen bolyongást követnek (illetve eltolásos véletlen bolyongást (random walk with drift), mivel az elvárt hozam, nem feltétlenül nulla). A hozamok múltbeli alakulásából tehát nem lehet következtetni a jövőre; az egyik legjobb előrejelzésünk a jövőbeli hozamra a historikus átlag. Egy hatékony piacon az átlagon felüli kockázattal súlyozott hozam elérése csak a véletlennek köszönhető, és hosszú távon nem fenntartható. Mindezekből az is következik, hogy nem jön létre arbitrázslehetőség, mivel minden új információ késedelem nélkül beépül az árfolyamba (Fama, 1970; Fama, 1991; Malkiel, 2005).

Megkülönböztethetjük a piaci hatékonyság három - gyenge, közepesen erős és erős formáját. Az elmélet gyenge formája szerint a múlt adataiból nem jelezhetők előre a jövőbeli hozamok. A közepesen erős forma szerint már minden nyilvánosan elérhető információ is beépül az árfolyamba. Míg az erős formánál pedig már nemcsak a nyilvánosan elérhető, hanem minden információt beépül a piaci árba (Fama, 1970).

Grossman és Stiglitz (1980) megmutatták, hogy a költségmentes információ szükséges feltétele az eredetileg definiált hatékonyságnak, mivel ha a kondíció gyenge formáját alkalmaznánk, akkor egy befektetőnek sem állna érdekében a költséges információ megszerzése, hiszen arbitrázsmentes piacon ezért nem kapna kompenzációt. Ha az 
információhoz olcsón hozzá lehet férni, akkor viszont a piaci ár nagyrészt tükrözi az informált befektetők értesüléseit. Erre egy példa a negyedéves jelentések közzétételének időpontja, amikor a pontos információk nagyon széles körben elérhetőek, amely időlegesen megnöveli a részvény likviditását (Váradi et al. 2012). Amikor a továbbiakban a hatékonyság híveire hivatkozunk, akkor minden esetben erre a lazábban értelmezett hipotézisre utalunk vissza.

\subsubsection{A hatékony piacok kritikái, a közepesen erős hatékonyság tesztjei}

Ez az alfejezet a hatékony piacok kritikáinak és tesztjeinek irodalmát összegzi. Az új információk hatása mellett a részvényárfolyamok alakulását további tényezők, különböző pszichológiai elemek összessége, Akerlof és Shiller (2011) fogalomhasználatával élve a lelki tényezők (animal spirits) is befolyásolják.

A kutatási kérdéseinkhez legszorosabban kapcsolódó elméleti keretet a piaci hatékonyság közepesen erős formájának tesztjei jelentik. Ezek az eseményelemzések vizsgálják ugyanis azt, hogy az új információ megjelenésének hatására hogyan reagálnak a részvényárfolyamok. Egy hatékony piacon egy meglepetésszerü sokk hatásának szinte azonnal és teljesen meg kellene mutatkoznia a piaci árban. Kiterjedt irodalom tárgyalja viszont azokat az eseteket, amikor ez nem történik meg. Alapvetően két mögöttes ok merül fel; vagy valóban lassan alkalmazkodnak az árfolyamok, vagy bizonyos kockázati prémiumokat az árazási modell nem foglal magában, így a használatával abnormális hozamokat mutathatunk ki (Bernard \& Thomas, 1989).

Fama és French (1996), illetve Fama (1998) a rövid távú hozamok kontinuitása mellett fontos anomáliaként említik meg a vállalatok jelentései után fennálló momentumot, másképpen árfolyamtrendet, hosszabb időszakon keresztül azonos irányú árfolyamváltozások sorát, amire a háromfaktoros modell sem ad választ.

Chan et al. (1996) két lehetséges viselkedési mintát említ, amely a közzététel utáni momentumot okozza. Az egyik, hogy a piaci reakció az indokolthoz képest gyenge, ezért 
az új hír lassabban épül be az árba. A másik lehetőség, hogy a trendet kihasználó kereskedők erősítik az árfolyammozgást, függetlenül attól, hogy ezt a fundamentumok indokolják-e. Mindkét magyarázatra épülnek viselkedési modellek (Barberis et al., 1998, Daniel et al., 1998).

Több kutató is megemlíti, hogy a különböző kognitív torzítások hatása jelentősebb illikvid részvényeknél (Chordia et al. 2009, Chordia et al., 2014), illetve azokban az esetekben, amikor egy vállalat értékelése körül nagyobb a bizonytalanság (Daniel \& Titman, 1999; Hirshleifer, 2001; Kumar, 2009). Zhang (2006), valamint Francis et al. (2007) kutatásai alátámasztják, hogy a meglepetéstartalommal bíró híreket követően az ár-reakció lassúbb a bizonytalanabb értékeltségü, növekedési részvények esetén.

\subsubsection{Az anomáliák viselkedési közgazdaságtani háttere}

Ez az alfejezet a tapasztalt piaci hatékonyságot érintő anomáliák viselkedési közgazdaságtani hátterét mutatja be. A korábbi alfejezetben ismertetett anomáliák alapján egyértelmüen felmerül a kérdés, hogy hogyan érvényesülnek a pszichológiai hatások az ármozgásokban. Akerlof és Shiller (2011) szerint a tapasztalt gyakran szélsőséges árfolyammozgásokat lehetetlen kizárólag fundamentális okokra visszavezetni és pusztán a racionális viselkedésnek tulajdonítani.

Malkiel (2003), Danielsson et al. (2009) és Soros (2003, pp. 49-72) szerint nem csak a fundamentumok és a valós kockázat változásai, hanem a befektetők által észlelt kockázat is befolyásolja a befektetők viselkedésüket és így a piaci árat. Alacsony észlelt kockázat mellett nő a kockázatvállalási hajlandóság, ami megnövelheti a tőkeáttétel is és ezen keresztül az árfolyamok kilengését (Berlinger, et al., 2012).

Kahneman és Tversky (1979) kilátáselmélete (illetve annak továbbfejlesztett változata a kumulatív kilátáselmélet - Kahneman és Tversky, 1992) szerint általában pontatlanul becsüljük meg a valószínűségeket: a szélsőségesen kis valószínűségekkel rendelkező események előfordulását felülbecsüljük. Kahneman és Tversky (1979) alapján a módosított értékfüggvény nem szimmetrikus: a hasznosságunk általánosan nagyobb mértékben csökken ugyanolyan mértékü veszteség esetén, mint amennyivel nyereség 
esetén nő. Ez megmagyarázhatja, hogy a veszteségtől való félelem miért okozhat komoly áreséseket negatív hírek hatására.

Kahneman és Tversky által leírt reprezentativitás (representativeness heuristic) is felelös lehet a túlzott ár-reakciókért: a valószínüség becslésekor nem a teljes eloszlást veszik figyelembe a befektetők, hanem felülértékelik az időben közelebb eső hozamokat, azt tekintik reprezentatív mintának, és okozatiságot feltételeznek a hozamok véletlenszerü klasztereződése mögött (Kahneman (2013), Kahneman és Riepe (1998), Hirschleifer (2001)). Ehhez kapcsolódó torzítás még a túlzott magabiztosság (overconfidence): az emberek felülbecsülik saját becsléseik pontosságát (Kahneman \& Riepe, 1998) és még a nyilvános bejelentésekkel szemben is képesek jobban bízni a saját információkban, elemzéseikben, minthogy figyelembe vegyék a saját elemzéseik a hibáját. Ezt tovább erősítő jelenség az önértékelési hajlam (self-attribution bias): a szerencsés kimeneteleket az emberek a saját képességeiknek tulajdonítják, míg az ezzel ellentétes eseményeket viszont zajnak. Mindezen torzítások felelősek lehetnek az árfolyamokban érzékelt túlreagálásokra, és az azokat követő korrekciókra (Daniel és Titman (1999), Daniel et al. (2001)).

Ugyanakkor léteznek ezzel ellentétes viselkedésbeli torzítások is, mint például a konzervativizmus (conservatism) (Barberis et al. (1998)): amikor új információkra a befektetők átmeneti, egyszeri hatásként tekintenek, így az nem, vagy nem teljesen jelenik meg az árfolyamban, és csak ha a szereplök trendszerüséget látnak az új információk sorában, akkor reagál a változásokra az árfolyam teljes egészében. Chan, et al. (1996) szerint ennek oka a lassan változó elemzői várakozásokban keresendő, mivel az ő előrejelzéseik erősen befolyásolják a piaci szereplőket. Brown, et al. (2013) alapján a nagy intézményi befektetők figyelembe veszik az elemzői előrejelzéseket, és az ő lépéseik hatására csordaszellem (herding) alakulhat ki, ami szélsőséges árfolyamkilengésekhez vezethet.

A korlátozott, vagy megosztott figyelem (adott részvényhez nem kötődő, de fontos egyéb bejelentések hatása) is okozhat visszafogott árfolyammozgásokat, ami lassú reakciót eredményezhet Hou et al (2009), Hirschleifer (2009), deHaan, et al. (2015) megfigyelése szerint a rossz híreket a menedzserek igyekeznek tőzsdezárás után vagy mozgalmas 
napokon közölni, amikor kevesebb figyelem tudja követni azokat. Hasonló empirikus megfigyelés, hogy a menedzserek, amennyire tehetik megpróbálják el is titkolni a nyilvánosság elől a kellemetlen híreket, veszteségeket, ahogy ezt Berlinger et al. (2018) is megállapította.

Fama (1998) szerint a hatékony piacok elmélete jobb általános magyarázatot nyújt a viselkedési közgazdaságtani megközelítésnél. Az alternatív elméletek megállapításait ugyanakkor mégis érdemes figyelembe venni, mivel több jelenség esetén hasznos meglátásokat és elméleti alapokat szolgáltatnak.

\subsubsection{Piaci hatékonyság és az arbitrázshozamok megléte}

Ebben az alfejezetben azt a kérdést járjuk körül a szakirodalom alapján, hogy a piaci hatékonyság megléte egyenlő-e azzal a megfigyeléssel, hogy a piaci szereplők túlnyomó többsége nem képes tartósan arbitrázshozamot realizálni. A viselkedési közgazdaságtan eredményei ellenére nyitott kérdés, hogy ha a hozamok valamilyen szinten előrejelezhetők az irracionális ár-reakciók miatt, akkor lehetséges-e tartós és szignifikáns többlethozamokat elérni a piaci hozamhoz viszonyítva. A passzív portfóliók ugyanakkor mégis képesek gyakran felülteljesíeteni az aktív portfóliókezeléssel szemben az utóbbi esetén jellemző magas tranzakciós költségek miatt (Malkiel, 2005).

Bár több példa és befektető is ismert, akik tartósan képesek felülteljesíteni a piaci hozamot aktív befektetési stílussal (Schwager, 2012a; Schwager, 2012b), de ezen esetek és szereplök relatíve ritkák, a meg-megjelenő arbitrázslehetőségek nem teljesen kockázatmentesek és általában a felismerésüket követően hamar megszünnek (Daniel \& Titman, 1999; Malkiel, 2003).

Ugyanakkor az arbitrázs lehetőségek hiánya, és az árfolyamok valós értékeltséghez közeli szintje nem ekvivalens megállapítások. Míg a helyes árazásból következik az arbitrázsmentesség és piaci hatékonyság, addig abból, hogy a szereplök általában nem találnak arbitrázslehetőségeket nem következik a piaci hatékonyság és az, hogy a piac helyesen értékeli az árfolyamokban a valós fundamentumokat (Barberis \& Thaler, 2003). 
A legsikeresebb befektetők ritka példái ugyanakkor azt bizonyítják, hogy a félreárazásból fakadó arbitrázslehetőségek nem gyakoriak és nehéz őket kihasználni. Mivel azonban a piaci szereplők sem nem tökéletesen informáltak, sem nem mentesek a viselkedési közgazdaságtan által leírt viselkedésbeli torzításoktól, így magyarázható, hogy miért maradhatnak fenn a valóságos fundamentumoktól akár hosszabb időre is eltávolodó árfolyamok és árfolyamtrendek.

\subsubsection{A piaci hatékonyság tesztelése az eseményelemzés módszertanával}

A piaci hatékonyságnak az eseményelemzés módszertanával történő elemzésére több példát találunk a szakirodalomban. Ezek között vegyesen találunk olyanokat, amelyek a vállalati jelentéseket övező időszakokban szignifikáns, illetve inszignifikáns abnormális hozamokat mutatnak ki:

Watts (1978) a negyedéves jelentések hatását vizsgálja kumulált abnormális hozamok szignifikáns jelenlétét keresve 73 NYSE vállalat 75 negyedéves jelentése körüli időszakban és szignifikáns abnormális hozamokat mutatott ki, bár azok mértéke nem haladta meg a kereskedés költségeit. Foster et al. (1984) 1974 és 1981 közötti 56000 negyedéves vállalati jelentést követően kialakuló trend meglétét vizsgálta az abnormális hozamokon keresztül és felemás eredményekre jutott: a trend megléte nem mindig bizonyult szignifikánsnak.

Pellicer és Rees (1999) 660 vállalati jelentés hatását vizsgálta 1991 és 1995 között Spanyolországban és szignifikáns abnormális hozamokat, volatilitást és bétanövekedést talált. Skinner és Sloan (2002) 1984 és 1996 közötti 103274 negyedéves jelentés körül vizsgálta az abnormális hozamok jelenlétét és arra a megállapításra jutott, hogy a növekedési részvények érzékenyebben reagálnak a negatív hírekre, mint az érték típusú részvények. Mallikarjunappa és Dsouza (2014) az indiai tőzsde (Bombay Stock Exchange (BSE)) 185 vállalatának 2011 decemberi negyedéves jelentései körüli 30-30 napos időszakát vizsgálta és szignifikáns abnormális hozamokat mutatott ki. Az általunk végzett elemzés pedig a kimutatott szignifikáns abnormális hozamok körét gyarapítja. 


\subsection{AZ ESEMÉNYELEMZÉS MÓDSZERTANA}

Ebben a fejezetben az eseményelemzés módszertanát mutatjuk be az irodalom alapján. Ezt az elemzési eszközt az utóbbi néhány évtizedben egyre több tudományterületen alkalmazzák, és az empirikus pénzügyekben betöltött jelentős szerepéhez nem füződhet kétség. A metodológia ismertetésében alapvetően MacKinlay (1997), Binder (1998), Kothari és Warner (2007), valamint Corrado (2011) tanulmányaira építünk, amelyek átfogóan tekintik át az elemzési procedúrát. Ezek alapján bemutatjuk az eseményelemzési eljárás menetét, illetve a kutatásunk szempontjából a legfontosabb módszertani részleteket. A módszertani ismertetésben MacKinlay (1997) jelöléseit követjük. A fejezetben tárgyaltak a Rácz és Huszár (2018) kéziratcikkünkre, illetve a Rácz és Huszár (2019, pp. 247-251.) cikkünkben leírtakra épülnek.

\section{Az eljárás lépései}

A pénzügyekben a vizsgált kérdés az elemzés során bizonyos értékpapírokban megmutatkozó árfolyamváltozás valamilyen gazdasági esemény következtében. Pontosabban megfogalmazva arra keressük a választ, hogy megfigyelhető-e abnormális hozam az adott esemény hatására.

Az első lépés minden esetben a vizsgálandó esemény és a hozzá kapcsolódó eseményablak (event window), tehát az esemény körül megfigyelt időszak meghatározása. Ezt követi a minta kiválasztása különböző szelekciós kritériumok alapján. Ezután szükséges meghatározni, hogy hogyan mérjük az abnormális hozamokat. Ezt az alábbi egyenlet fejezi ki:

$$
A R_{i \tau}=R_{i \tau}-E\left(R_{i \tau} \mid X_{\tau}\right)
$$

ahol $A R_{i \tau}$ az $i$-edik részvény $\tau$ időperiódusra vonatkozó abnormális hozamát, $R_{i \tau}$ a ténylegesen realizált hozamát, $E\left(R_{i \tau} \mid X_{i \tau}\right)$ pedig a várható hozamát jelöli. $X_{\tau}$ a várható hozam feltétele, amit az elérhető információk és az alkalmazott eszközárazási modell határoz meg (MacKinlay, 1997; Kothari \& Warner, 2007; Corrado, 2011). 


\subsubsection{A várható hozamok modellezése}

Ez az alfejezet a várható hozamok modellezésének lépéseit foglalja össze a szakirodalom alapján. A várható hozamok számítása során feltesszük, hogy a modellezéshez használt hozamok normális eloszlást követnek, valamint időben függetlenek és azonos eloszlásúak. MacKinlay (1997) szerint alapvetően két modell használata jellemző az eseményelemzések többségére: a konstans várható érték modell és a piaci modell. A konstans várható értékü modellt gyakran egy naiv megközelítésnek tekintik a szakirodalomban, mivel nem választja külön a vállalatspecifikus, illetve a piacspecifikus információk részvényárfolyamra gyakorolt hatását (Cable és Holland (1999), Corrado (2011)). Emiatt nehéz lehet megállapítani, hogy a megfigyelt abnormális hozamokat a vizsgált esemény idézi-e elő, vagy a piac kilengései okozzák-e.

Ennél kifinomultabb megoldást kínál a piaci modell, amely már a CAPM-modellhez (Capital Asset Pricing Modell - Tőkepiaci Árfolyamok Modellje; Sharpe (1964), Lintner (1965)) hasonlóan magában foglalja az értékpapír és a piaci portfólió hozamának viszonyát, így csökkenti az abnormális hozam varianciáját, és pontosítja az esemény hatásának számszerüsítését (MacKinlay (1997), Corrado (2011)):

$$
\begin{aligned}
& R_{i t}=\alpha_{i}+ \beta_{i} R_{m t}+\varepsilon_{i t}, \\
& \varepsilon_{i t} \sim N\left(0, \sigma_{\varepsilon_{i}}^{2}\right),
\end{aligned}
$$

ahol $R_{i t}$ és $R_{m t}$ az $i$-edik részvény, illetve a piaci portfólió $t$ periódusbeli hozamai, $\alpha_{i}$ és $\beta_{i}$ a regressziós modellből becsülendő paraméterek. A $\beta_{i}$ együttható az $i$-edik részvény érzékenységét mutatja meg a piaci portfólióra, az $\alpha_{i}$ az illeszkedést segítő paraméter, $\varepsilon_{i t}$ pedig az értékpapír $t$ periódusban megfigyelhető hibatagja. Feltételezzük, hogy a hibatag nulla várható értékü és $\sigma_{\varepsilon_{i}}^{2}$ varianciájú normális eloszlást követ.

Az alkalmazott modellezési logikánk azzal a feltételezéssel él, hogy a regressziós együtthatók a becslési időszakban és az eseményablakban egyaránt konstansak (Binder, 1998). Egy adott részvény valós bétája időben változhat, rövid időhorizontot vizsgálva azonban valószínűtlen, hogy jelentős változások történnek a kockázati profilokban. 
Számos módszerrel lehet a várható hozamokat modellezni, mint például a többfaktoros modellek, de az addicionális faktorok magyarázó ereje általában marginális a piaci modellhez viszonyítva (MacKinlay, 1997). MacKinlay (1997), illetve Cable és Holland (1999) szerint a piaci modell a tesztek során jobban teljesít a CAPM-nél. Bár mindkét modell pontatlanabb becslését adja a valós abnormális hozamoknak, mint a többfaktoros modellek (például Fama és French 1996). A torzítás nagy minták esetén viszont nullához közelít, így a piaci modell hatékony módja a hozamok becslésének (Binder, 1998), és további faktorok bevezetésének hatása elhanyagolható (MacKinlay, 1997). Mindezek konklúziójaként a továbbiakban a piaci modellt használjuk a normális hozamok kiszámításához.

\subsubsection{Az eseményablak és a becslési ablak hossza}

Ebben az alfejezetben annak megfontolásait foglaljuk össze, hogy a szakirodalom szerint milyen hosszú eseményablakot és becslési ablakot használjunk az elemzés végrehajtásához. Ezek megválasztása valamelyest önkényes, alapvetően a korábbi kutatások tapasztalataira alapozva határoztuk meg az időtartamokat. A vizsgált témánk az eseményelemzések között rövid idöhorizontúnak tekinthetö, így egy viszonylag rövid eseményablak megfelelő választás a hipotézisek tesztelésére. Egy évnél rövidebb eseményablak esetén elég megbízhatóan müködik az elemzés, és jóval kevesebb módszertani probléma merül fel a számítások során (Kothari \& Warner, 2007).

Esetünkben az esemény dátumán kívül legalább a rákövetkező kereskedési napnak az eseményablak részét kell képeznie, hogy a kereskedési nap végi vagy a tőzsde zárását követő közzétételek is figyelembe legyenek véve, hiszen ekkor szükségszerüen jelentkezik abnormális hozam a következő napon is. Különösen jelentős ez a hatás akkor, ha a közzététel rossz híreket tartalmaz a befektetőkre nézve (deHaan, et al. (2015), Doyle és Magilke (2015)). Általában a gyakorlatban egy néhány hétből álló intervallum a megszokott, ami jellemzően szimmetrikus az esemény dátumára (MacKinlay, 1997).

Minél rövidebb az eseményablak, annál kisebb eséllyel fordulhat elő a vállalatokat érintő más eseményekből adódó torzító hatás (Rao \& Sreejith, 2014). Esetünkben a vállalati 
jelentésekhez kapcsolódó gazdaságilag is szignifikáns abnormális hozamokra csak az esemény körüli néhány napban számíthatunk. MacKinlay (1997) cikkében is megfigyelhető, hogy a jelentés közzététele után néhány nappal az abnormális hozamok a várható értékük, tehát nulla körül ingadoznak. Egy négyhetes ablak tehát megfelelő választásnak tűnik.

Fontos figyelembe venni, hogy ha az eseményablak túl hosszú a becslési időszakhoz képest, az jelentősen torzíthatja a tesztstatisztikát abban az esetben, ha a becsült abnormális hozamok korreláltak. Viszont például egy 5 napos eseményablak és 100 napos becslési ablak esetén a torzított tesztstatisztika értéke várhatóan mindössze 1,6\%kal haladja meg a torzítatlant (Binder, 1998). Esetünkben célszerűnek tűnik ezért a MacKinlay (1997) által használt 120 napnál hosszabb, például egy kétéves (500 kereskedési napos) időszakból számítani a regressziós együtthatókat, ahogy azt Corrado (2011) is javasolja. Lényeges a két ablak időbeli különválasztása is; ha az eseményablak hozamadatait is felhasználnánk a regressziós modellhez, akkor hibás paraméterbecslést kapnánk, mert az már tartalmazná a bejelentés következtében jelentkező zajt is (Boehmer, et al., 1991; MacKinlay, 1997; Binder, 1998; Kothari \& Warner, 2007).

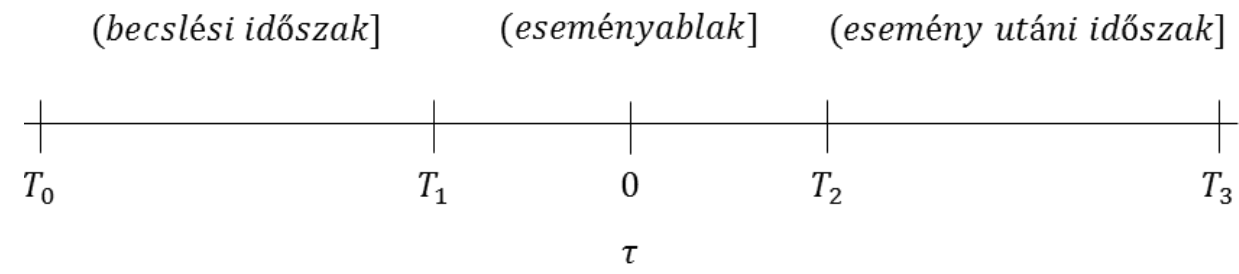

\section{1. ábra: Egy eseményelemzés időrendje (MacKinlay, 1997, p. 20).}

A fentiek tükrében formálisan a következőképpen írhatjuk le az eseményelemzés időrendjét. A hozamok futóindexe $\tau$, és a következőképpen alakulnak az elemzés szakaszai. $\tau=0$ az esemény dátuma, $T_{0}+1 \leq \tau \leq T_{1}$, a becslési ablak, $T_{1}+1 \leq \tau \leq$ $T_{2}$ pedig az eseményablak. Ekkor $L_{1}=T_{1}-T_{0}$ a becslési ablak, $L_{2}=T_{2}-T_{1}$ az eseményablak hossza (lásd 1. ábra). Meg lehet határozni egy esemény utáni időszakot/ablakot is (post-event window), amelyet $T_{2}+1 \leq \tau \leq T_{3}$ ír le, és hossza $L_{3}=$ $T_{3}-T_{2}$, de a kutatási kérdéseink szempontjából erre nincs szükség. 


\subsubsection{Az abnormális hozamok mérése és tesztelése}

Ez az alfejezet az abnormális hozamok mérésének és tesztelésének kérdéseit összegzi a szakirodalom alapján. Miután kiválasztottuk, hogy milyen módszerrel modellezzük a várható hozamot (amely a piaci portfólió hozamának lineáris függvénye), az (1) és (2) egyenleteket felhasználva pontosabban leírható a disszertációban használt abnormális hozam definíció:

$$
A R_{i \tau}=R_{i \tau}-E\left(R_{i \tau} \mid R_{m \tau}\right),
$$

ahol $T_{1}+1 \leq \tau \leq T_{2}$, tehát $\tau$ egy eseményablakbeli periódust jelöl. Meghatározásra került továbbá a paraméterbecsléshez használt és az esemény körüli időszakok hossza, így hozzáfoghatunk a regressziós modell felépítéséhez. A paraméterek becslése a legkisebb négyzetek módszerével (ordinary least squares, OLS) történik. (2) alapján ismerjük a modellezés során számított várható hozamot, így ezt a (3) egyenletbe behelyettesítve a következőképpen számíthatók ki az esemény körül az abnormális hozamok:

$$
A R_{i \tau}=R_{i \tau}-\left(\hat{\alpha}_{i}+\hat{\beta}_{i} R_{m \tau}\right)
$$

ahol $A R_{i \tau}$ az $i$ részvény abnormális hozama, $R_{i \tau}$ és $R_{m \tau}$ az $i$-edik részvény, illetve a piaci portfólió hozamai, a $\tau$ periódusban. A piaci hozamra való érzékenységet kifejező becsült regressziós együttható $\hat{\beta}_{i}, \hat{\alpha}_{i}$ pedig az illeszkedést segítő paraméter.

Ahhoz, hogy statisztikailag, illetve gazdaságilag releváns következtetéseket lehessen levonni a kutatási kérdéseket illetően, nyilvánvalóan szükséges aggregálni a kiszámított abnormális hozamokat. Ez történhet a minta elemei, valamint az idő dimenziója mentén. Első hipotézisünk első része azt mondja ki, hogy az EPS-ben mutatkozó meglepetés iránya és nagysága határozza meg a részvényárfolyam reakcióit a bejelentés hatására. Ez a feltételezés például úgy tesztelhető hatékonyan, ha aggregáljuk a vállalat közzétételekor jelentkező abnormális hozamokat a mintában aszerint, hogy a meglepetés pozitív, negatív vagy semleges. MacKinlay (1997), Binder (1998), Serra (2004), illetve Kothari és Warner (2007) alapján ez az átlagos abnormális hozam a $\tau$ periódusban $\left(\overline{A R}_{\tau}\right)$ a csoportok elemeinek adataiból számított számtani átlag: 


$$
\overline{A R}_{\tau}=\sum_{i=1}^{N} \frac{A R_{i \tau}}{N},
$$

ahol $N$ a mintaelemszámot (illetve a csoport elemszámát), tehát a megfigyelt események számát jelöli. Magas $L_{1}$ érték esetén a varianciája (vesd össze. MacKinlay (1997, p. 21) tanulmányának (8) egyenletével).

$$
\operatorname{var}\left(\overline{A R}_{\tau}\right)=\frac{1}{N^{2}} \sum_{i=1}^{N} \sigma_{\varepsilon_{i}}^{2} .
$$

Azért szükséges a viszonylag hosszú becslési időszak, mert a (6) egyenlet akkor igaz, ha az abnormális hozamok egymástól időben függetlenek. MacKinlay (1997) szerint ez teljesül, amennyiben kellően nagy minta alapján végezzük a hozambecsléseket. Mivel $\sigma_{\varepsilon_{i}}^{2}$ nem ismert, ezért erre egy becslést kell alkalmaznunk a variancia számításakor. MacKinlay (1997) és Binder (1998) alapján a (2) egyenletben leírt hibatag varianciája megfelelő választás a számoláshoz, és ez a következőképpen írható fel $L_{1}=T_{1}-T_{0}$, azaz a becslési ablak hosszának függvényében:

$$
\hat{\sigma}_{\varepsilon_{i}}^{2}=\frac{1}{L_{1}-2} \sum_{\tau=T_{0}+1}^{T_{1}}\left(R_{i \tau}-\hat{\alpha}_{i}-\hat{\beta}_{i} R_{m \tau}\right)^{2} .
$$

Ezek után már tesztelhető a nullhipotézis, miszerint $\overline{A R}_{\tau}$ nulla várható értékü normális eloszlást követ, tehát

$$
\overline{A R}_{\tau} \sim N\left[0, \operatorname{var}\left(\overline{A R}_{\tau}\right)\right] .
$$

Fontos megemlíteni, hogy az átlagos abnormális hozam statisztikai szignifikanciájának teszteléséhez feltételezzük, hogy $\tau$ időperiódusban az egyes megfigyelések $A R_{i \tau}$ abnormális hozamai függetlenek és azonos eloszlást követnek. MacKinlay (1997) és Binder (1998) megjegyzik, hogy a keresztmetszeti adatok gyakran korreláltak. Ebböl nem fakad becslési probléma, ha az egyes megfigyelések eseményablakai nincsenek átfedésben egymással. Ellenkező esetben nem feltételezhetjük, hogy a mintaelemek becsült abnormális hozamai függetlenek, és ekkor a köztük lévő nem nulla kovariancia lefelé torzítja a varianciabecslést, ezáltal felfelé a tesztstatisztikát. Binder (1998) szerint a torzító hatás elhanyagolható, ha a vizsgálandó értékpapírok kiválasztása nem koncentrálódik iparágakra, és a piaci modellt használjuk. Rao és Sreejith (2014) pedig kifejtik, hogy az események véletlenszerủ eloszlása is véd a torzítás ellen. 
Ha a vállalati jelentések meglepetéshatását és a piaci hatékonyságot is tesztelni szeretnénk, akkor a jelentés napját, valamint - kései vagy kereskedési órákon kívüli jelentés esetén - az azt követő kereskedési napot is magában foglaló intervallumnál hosszabb időszakot kell elemeznünk. Erről szól az első hipotézis második része is. A korábban már hivatkozott empirikus eredmények alapján jogosan feltételezhetjük, hogy a vállalatok eredményében jelentkező meglepetés miatt rövid távon megfigyelhetünk momentumhatást az árfolyamokban.

Ahhoz, hogy ezt a feltételezést is tesztelni tudjuk, már szükség van arra, hogy az abnormális hozamokat, az eseményablakon belül, időben is aggregáljuk. Tekintsünk egy $\tau_{1}$ és $\tau_{2}$ által bezárt időtartamot, amire teljesül, hogy $T_{1}<\tau_{1} \leq \tau_{2} \leq T_{2}$. Ekkor legyen az $i$ részvény ezen intervallumon megfigyelhető kumulatív abnormális hozama $(C A R)$

$$
C A R_{i}\left(\tau_{1}, \tau_{2}\right)=\sum_{\tau=\tau_{1}}^{\tau_{2}} A R_{i \tau}
$$

Ugyanezt a müveletet elvégezhetjük a minta, illetve az abból képzett csoportok egyes elemeire kiszámított átlagos abnormális hozamai esetén is, így megkaphatjuk a kumulatív átlagos abnormális hozamokat az eseményablak tetszőleges $\left(\tau_{1}, \tau_{2}\right)$ intervallumára.

$$
\begin{aligned}
\overline{C A R}\left(\tau_{1}, \tau_{2}\right) & =\sum_{\tau=\tau_{1}}^{\tau_{2}} \overline{A R}_{\tau}, \\
\operatorname{var}\left(\overline{C A R}\left(\tau_{1}, \tau_{2}\right)\right) & =\sum_{\tau=\tau_{1}}^{\tau_{2}} \operatorname{var}\left(\overline{A R}_{\tau}\right)
\end{aligned}
$$

ahol $\overline{A R}_{\tau}$ és $\operatorname{var}\left(\overline{A R}_{\tau}\right)$ a (5) és (6) egyenletekből ismertek (MacKinlay, 1997; Binder, 1998).

Mindezek alapján lehetőség nyílik a következő nullhipotézis tesztelésére miszerint a kumulatív átlagos abnormális hozam is nulla várható értékű normális eloszlást követ, tehát

$$
\overline{C A R}\left(\tau_{1}, \tau_{2}\right) \sim N\left[0, \operatorname{var}\left(\overline{C A R}\left(\tau_{1}, \tau_{2}\right)\right)\right]
$$


illetve normalizálva

$$
\theta=\frac{\overline{C A R}\left(\tau_{1}, \tau_{2}\right)}{\sqrt{\operatorname{var}\left(\overline{C A R}\left(\tau_{1}, \tau_{2}\right)\right)}} \sim N(0,1)
$$

Ezzel át is tekintettük a tanulmány hipotéziseit vizsgáló módszertan főbb pontjait. A második hipotézis esetében is hasonlóképpen járunk el. Itt szükség lesz még annak tesztelésére, hogy a két mintából kapott eredmények szignifikánsan különböznek-e egymástól, ugyanolyan várható értékü és varianciájú eloszlást követnek-e a kumulatív átlagos abnormális hozamaik. 


\subsection{A BEFEKTETÉSI ALAPOK TELJESÍTMÉNY- ÉRTÉKELÉSÉNEK IRODALMA}

Ez a fejezet áttekinti a befektetési alapok teljesítményértékelésének a szakirodalmát, a különféle mutatószámok jellemzőit és fejlődését, valamint bemutatja a teljesítménymanipulálás kérdéskörét, és az ennek kivédését lehetővé tevő mutatószámokat, illetve az alkalmazásuk segítségével a hozammanipuláció kimutatásának lehetőségeit, továbbá a hozammanipuláció kimutatásának további alternatív módszereit. A fejezetben tárgyaltak nagyrészt a Rácz (2019a) cikkünkben leírtakra épülnek.

A megtakarítások befektetési alapokba történő elhelyezése előtt a befektetőnek arról kell döntést hoznia, hogy melyik befektetési alaptól várhatja a hozamelvárásának és kockázatviselési hajlandóságának megfelelő teljesítményt a jövőben. A jövőre vonatkozóan nincsenek teljes bizonyosságú információink, és csak a múltbeli teljesítményből és viselkedésből indulhatunk ki a várakozásaink kialakításához. Az aktívan menedzselt befektetési alapok esetében a megtakarításunk kezelését egy befektetési alapkezelőre bízzuk, így ebben az esetben a várakozásainkat az adott befektetési alap múltbeli viselkedéséből kiindulva tudjuk csak kialakítani.

Mivel a befektetési alap kezelöje is tisztában van azzal, hogy az általa kezelt befektetési alap múltbeli teljesítményét leíró mutatószámokból próbálunk következtetést levonni a jövőben várható teljesítményre, ezért amennyiben lehetősége van rá igyekszik a saját teljesítményét jobb színben feltüntetni, illetve egy megadott keretrendszeren belül igyekszik minél jobb teljesítményt elérni, akár olyan tudatos vagy tudattalan befektetési stratégiákkal, amik ugyan növelik a mutatószámok értékét, mégis lehetséges, hogy szuboptimálisak a befektetői hasznosság szempontjából, és ezért a szakirodalom teljesítménymanipulálásnak nevezi ezeket. A befektetési alap kezelője mindezek által igyekszik elérni, hogy minél vonzóbbnak tünjön az általa kezelt befektetési alap, és így minél több új forrást tudjon bevonni, amiből előbb-utóbb magasabb jutalékok csapódnak le a kezében. Zawadowski (2017) a befektetési alapkezelők jutalékközpontúságának szomorú összefüggését mutatta meg, ugyanis az eredményei szerint a magasabb jutalékot szedő befektetési alapkezelők nem képesek a magasabb jutalékért cserébe azt meghaladó 
mértékü többlethozamot produkálni, hanem épp ellenkezöleg, 1 százalékponttal magasabb kezelési díj átlagosan több mint 1 százalékponttal rosszabb teljesítménnyel (Jensen-alfával) párosul a referenciahozamhoz viszonyítva.

A viszonylag szigorú auditori tevékenység, valamint a független letétkezelői tevékenység mellett igen korlátozottak lehetnek a befektetési alapkezelők lehetőségei ahhoz, hogy képesek legyenek az értékelésre használt mutatószámok ismeretében a teljesítményük mesterséges és a valóságot érdemben befolyásoló manipulálására. A szakirodalomból viszont az tűnik ki, hogy nem csak egyes illikvid eszközeik nettó eszközértékének rugalmas értékelése és/vagy a veszteségek kisimított lejelentése által, hanem különféle szuboptimális és/vagy időben dinamikus befektetési döntések által is képesek lehetnek növelni a teljesítményértékelésre használt mutatószámok értékeit, miközben a valós teljesítményükben nincs tényleges javulás (Ingersoll et al. (2007)).

Számos aspektusból lehet tekinteni az aktívan menedzselt portfóliók, így az abszolút hozamú befektetési alapok értékelését: Amihud et al. (2014) az illikviditás beárazódásának hatását elemzi, és azt találja, hogy az IML-faktorra (az illikvid mínusz likvid részvényekből álló portfólió hozamára) való érzékenység (béta) szignifikáns a növekvő finanszírozási nehézségek időszakában. Gemmill et al. (2006) brit befektetési alapokat értékel a kilátáselméleten alapuló veszteségelkerülő teljesítménymutatóval és megállapítja, hogy más sorrendet kap eredményül, mint a hagyományos mutatókkal. Walter (2002) pedig bemutatja, hogy a befektetői preferenciákhoz illeszkedő alsóági kockázatokat figyelembe vevő limit- és prémiumrendszer körültekintés nélküli alkalmazásával olyan szélsőséges befektetési stratégia alakulhat ki, amely már nem felel meg az eredeti befektetõi szándékoknak. A kockázat igazságos felosztásának vizsgálatakor Csóka és Pintér (2016) belátja és Balog et al. (2017) megerősíti, hogy nincs kockázatfelosztási módszer, amely mindig értelmezett, egyszerre stabil és ösztönző.

A teljesítménymérő mutatószámok fejlődése során sikerült a korábbi megoldások hibáit orvosolni, ám az abszolút hozamú befektetési alapok értékelése esetében komoly problémát okoz a megfelelő benchmark-index hiánya. Egyik lehetséges megoldása ennek a problémának befektetési stílusokat megtestesítő faktorok felhasználásával az 
Információs Ráta módosított változatának a kiszámítása (Pojarliev és Levich (2013)). A szükséges faktorok alkalmazása ugyanakkor elég nehézkes ezen befektetési alapok esetében. Továbbá megoldandó problémát jelent az is, hogy a szakirodalomban elterjedt és a piac által jelenleg is használt mutatószámokkal kapcsolatban továbbra is fennáll a manipulálhatóság kérdésköre, amely nem csak az abszolút hozamú, hanem minden befektetési alapot és hedge fund-ot érintő jelenség. Több megközelítést is találunk az irodalomban a probléma áthidalására, amelyeknek a célja olyan új teljesítménymérő mutatószámok bevezetése, amelyek képesek a kockázat-hozam kombinációk helyes értékelésére még akkor is, ha a befektetési alap hozameloszlása abnormális, vagy ha felmerül a hozamok jelentésbeli simításának vagy manipulálásának lehetősége (Ingersoll et al. (2007)).

A probléma egyik lehetséges megoldása a Manipulációbiztos Teljesítménymutatók (MBTM-ek - angol eredetiben Manipulation-proof Performance Measure - MPPM) alkalmazása, melyek a mikroökonómiában jól ismert hasznosság-elméleten alapulnak. Ezek a mutatószámok, konstrukciójukból fakadóan különösen alkalmasak aktívan menedzselt alapok értékelésére, mivel a mutató értékének növelése csak akkor lehetséges, ha az alapkezelő menedzser tényleges információ vagy képesség birtokában van. Ezzel szemben pusztán annak az információnak az ismeretében nem, hogy a piac vagy teljesítményértékelő milyen mutatószámmal méri a teljesítményt. Ez a különleges tulajdonság jellemzi a Manipulációbiztos Teljesítménymutatókat (MBTM-eket) a klasszikus mérőszámokkal szemben, amelyek manipulálhatók többlettudás és információ nélkül is pusztán a mérőszám ismerete által. Bemutatjuk, hogy a manipulációbiztos mutatószámoknak milyen kritériumoknak kell eleget tenniük, valamint, hogy Ingersoll et al (2007) hogyan határozta meg a probléma egy lehetséges megoldását, hogyan néz ki az általuk definiált mutatószám, mely felépítésénél fogva alkalmas az abszolút hozamú befektetési alapok és hedge fund-ok teljesítményének értékelésére.

Kitérünk a Brown et al. (2010) féle megközelítésre, amely egy lineáris közelítése az Ingersoll et al. -féle képletnek és amelyet Brown et al. egyszerübb, könnyebben számítható formulaként mutatott be. A Brown et al. -féle megközelítés segítségével Brown et al. képes volt a mutató jobb strukturálására többlethozam és többletszórás 
formájában, amelynek segítségével a mutatót felhasználta az implikált kockázatelutasítás kiértékelésére is. Az így kapott új mutatószámot Kételkedési Hányadosnak (angol eredetiben Doubt Ratio) nevezték el, amely extrém értékek esetében jelezheti a hozamsimítás, vagy teljesítménymanipulálás jelenlétét.

A fejezet zárásaként bemutatjuk azokat a további alternatív technikákat és mutatószámokat, így a Torzítási Rátát és a Diszkontinuitás-elemzést, amelyek a hozameloszlás sajátosságaiból, és/vagy a hozamok 0-körüli eloszlásából következtetnek a potenciálisan meglévő hozamsimításra, vagy egyéb manipulációra (Abdulali (2006), Bollen és Pool (2009).

\subsubsection{Az abszolút hozamú befektetési alapok definíciója}

Az abszolút hozamú befektetési alapok aktívan menedzseltek, és eltérően a többi befektetési alaptól nem követnek benchmarkokat vagy indexeket, hanem azt a célt tüzték ki maguk elé, hogy minden piaci körülmény között pozitív hozamot érjenek el alacsony volatilitás mellett. Ez egyrészt azáltal lehetséges, hogy szofisztikáltabb pénzügyi termékeket, például származtatott termékeket is beépítenek a portfóliójukba és így védik magukat a veszteségek kockázatától, ugyanakkor magasabb hozamokat képesek generálni. Másrészt az alapkezelő nem csak abban kap szabad kezet, hogy nem egy előre megadott indexet kell követnie minden piaci körülmény között, hanem szabadabban dönthet az egyes eszközosztályok és befektetések portfólión belüli arányáról, szemben a hagyományos befektetési alapokkal, ahol a minimum és maximum arányok is elő vannak írva, így még akkor sem csökkentheti le egy adott eszközosztály arányát egy szintnél alacsonyabbra az alapkezelő, ha a megítélése szerint a piaci viszonyok ezt tennék szükségessé, így nem kerülhet el bizonyos veszteségeket, akkor sem, ha egyébként erre szakmai helyzetértékelése alapján képes lenne. 


\subsubsection{Klasszikus teljesítményértékelő mutatószámok}

Ebben az alfejezetben áttekintjük az irodalomban és az alkalmazásokban előforduló klasszikus teljesítményértékelő mutatószámokat, bemutatva a felépítésüket, a felépítésükhöz használt logikát, illetve, hogy az egyes változatok, a korábbiak milyen hibáit igyekeztek kezelni, és hogy az aktívan menedzselt alapok, de különösen az abszolút hozamú alapok esetében, milyen hiányosságok lépnek fel, ami miatt alternatív mutatószámok keresése felé kell fordulnunk.

\section{Sharpe-ráta}

A Sharpe-ráta William Sharpe-ról kapta a nevét (Sharpe, 1966). Az eredeti szándék szerint ez a mutatószám a kockázatmentes és kockázatos portfólióelemek optimális arányának meghatározására szolgál és a vállalt többletkockázatért járó többlethozamot méri. Minél magasabb a mutató értéke, annál magasabb az egységnyi kockázatra jutó többlethozam mértéke.

A Sharpe-ráta a következő:

$$
S=\frac{R_{p}-R_{f}}{\sigma_{p}}
$$

ahol $R_{p}$ a befektetési alap/portfólió hozama, $R_{f}$ a kockázatmentes hozam és $\sigma_{p}$ a befektetési alap/portfólió szórása.

Amennyiben a Sharpe-rátát teljesítményértékelésre használjuk, akkor az „csak" azt mutatja meg, hogy a befektetési alap megfelelő többlethozamot biztosít-e a vállalt többletkockázatért, de arról nem ad információt, hogy van-e és ha van, akkor milyen a kapcsolat a benchmark és a befektetési alap teljesítménye között. Másképpen megfogalmazva a Sharpe-ráta nem bontja meg a befektetési alap teljesítményét a piac/benchmark változásából fakadó teljesítményre, valamint a befektetési alapkezelő egyedi döntéseiből fakadó teljesítményre, amely abból fakad, hogy az nem mindig követi passzívan a benchmarkot, hanem ahhoz viszonyítva eltérő befektetési döntéseket hoz, vagy eltérő portfóliósúlyozást alkalmaz. Mindez azért probléma, mert a klasszikus aktívan menedzselt alapok egy indexet, vagy indexek meghatározott 
arányát követik, az alap által lefedett piacoknak megfelelően, és az alapkezelő azzal akarja bizonyítani a rátermettségét, hozzáértését (és a díjazása is nagyban függ attól), hogy képes-e többlethozamot generálni a benchmarknak választott indexhez (indexekhez) viszonyítva azáltal, hogy a befektetési célpontokból azokat súlyozza felül a benchmarkhoz képest, amelyeket az elemzései alapján felülteljesítő célpontoknak értékel a piaci indexekhez képest. Így a Sharpe-rátát használva nem rendelkezünk információval arról, hogy az alapkezelő, pontosan hogyan volt képes felül- vagy alulteljesíteni a benchmarkhoz képest.

\section{A Sharpe-ráta módosításai}

A Sortino-ráta (Sortino és Prince, 1994) a Sharpe-ráta egyik módosítása, amely a teljes szórás helyett, csak a veszteségek szórását veszi figyelembe, viszont a nyereségek szórását már nem. A Sortino-ráta tehát csak a veszteségek szórását tekinti leküzdendő akadálynak és kockázatnak, a nyereségek szórását nem, mivel azok összességében hasznosak a befektetőknek, még ha bizonytalansággal is járnak együtt.

$$
\text { Sortino }- \text { ráta }=\frac{R_{p}-R_{f}}{\sigma_{d}},
$$

ahol $R_{p}$ a befektetési alap/portfólió hozama, $R_{f}$ a kockázatmentes hozam és $\sigma_{d}$ a befektetési alap/portfólió veszteségeinek a szórása.

A Calmar-ráta (Young, 1991) a többlethozamot a megfigyelt időszak legnagyobb veszteségéhez (maximum drawdown) hasonlítja a szórás helyett. Így hasonlít a Sortino-rátához abban, hogy az alsó ági kockázatokhoz viszonyítja a hozamokat, de alsó ági szórás helyett a legnagyobb tapasztalt veszteséggel számol:

$$
\text { Calmar }- \text { ráta }=\frac{R_{p}-R_{f}}{\text { Max Drawdown }},
$$

ahol $R_{p}$ a befektetési alap/portfólió hozama, $R_{f}$ a kockázatmentes hozam és a Max Drawdown, a legnagyobb tapasztalt veszteséget méri a megfigyelt időintervallumon.

Bár a Sortino- és Calmar-ráták a kockázatot talán pontosabban ragadják meg az alsóági kockázatok számszerüsítésével a Sharpe-rátánál, arra általuk sem kapunk 
magyarázatot, hogy a befektetési alapkezelö, hogyan képes a benchmarkhoz viszonyítottan felül-, illetve alulteljesíteni.

\section{Jensen-alfa}

A Jensen-alfa értékelési megközelítést három évvel a Sharpe-rátát követően írta le Michael C. Jensen (Jensen, 1969). A Jensen-alfa azt a többlethozamot számszerüsíti, amelyet egy olyan stratégia alkalmazásával lehet elérni, amelyet a meglévő és ismert magyarázó változók/faktorok segítségével nem lehet megmagyarázni. A $\beta_{i}$ az egyes befektetési eszközöknek a piaci portfólió többlethozamára vonatkozó érzékenysége. Így amíg a $\beta_{i}$ segítségével számolt hozam kockázattal korrigáltan kerül meghatározásra, addig a Jensen-alfa pusztán a többlethozamot méri, de nem számszerüsíti a vállalt többletkockázatot a piaci portfólióhoz/benchmarkhoz képest, és nem is korrigál azzal:

$$
\alpha=R_{p}-\left[R_{f}+\sum_{i} \beta_{i}\left(R_{m}-R_{f}\right)\right],
$$

ahol $R_{p}$ a befektetési alap/portfólió hozama, $R_{f}$ a kockázatmentes hozam, $R_{m}$ a piaci portfólió/benchmark hozama, $\beta_{i}$ az egyes befektetési eszközöknek a piaci portfólió többlethozamára vonatkozó érzékenysége, végül $\alpha$ a befektetési alap/portfólió azon többlethozama, amit nem lehet megmagyarázni $\beta_{i}$-k segítségével.

A szakirodalomban a Jensen-alfa az egyik legelterjedtebben használt mutató, mivel közérthetően mutatja az alul- vagy felülteljesítést/többlethozamot a benchmarkindexhez/indexekhez képest, és a kiszámítása is viszonylag egyszerü. Ugyanakkor a hátránya az, hogy csak azt mutatja meg, hogy milyen hozamot ért el az alapkezelö a benchmarkhoz viszonyítva, de hogy ehhez milyen többletkockázatot vállalt az alapkezelő, azaz, hogy mennyivel kockázatosabb az általa felülsúlyozásokkal kialakított portfólió a benchmarkhoz képest, arról nem mond semmit. 


\section{Információs Ráta}

Egy módja a vállalt többletkockázat mérésének, ha az Jensen-alfát elosztjuk a Jensenalfa szórásával, és így megkapjuk az Információs Rátát (IR), amelyet Treynor és Black vezetett be 1973-ban (Treynor és Black, 1973). Az Információs Ráta azt mutatja meg, hogy az alapkezelő aktívan vállalt kockázati egységre vetítve milyen többlethozamot ért el.

$$
I R=\frac{\alpha}{\sigma_{\alpha}}
$$

ahol $\alpha$ a befektetési alap/portfólió többlethozama, $\sigma_{\alpha}$ pedig az $\alpha$ szórása.

Az Információs Ráta lényegében a Sharpe-ráta módosítása oly módon, hogy a kockázatmentes hozam helyett a benchmarkhoz viszonyított többlethozamot arányosítja a benchmarkhoz képest vállalt többletkockázathoz. Hasonlóan a Jensenalfához, könnyen értelmezhető eredményt ad, és relatíve egyszerü a kiszámítása is.

Az Információs Ráta mérése könnyü azon esetekben, amikor a benchmark már adott, mint például a piaci indexeket követő ETF-ek (Exchange Traded Funds - Tőzsdén Kereskedett Befektetési Alapok) esetében. Ám abszolút hozamú alapok esetében nem magától értetődő, hogy mi az a benchmark-index, amihez viszonyítva helyes teljesítményértékelésre juthatunk, hiszen ezen befektetési alapok nem követnek egyértelmúen és jól meghatározott indexet vagy indexeket. Ehelyett minden piaci körülmény között pozitív hozam elérése a kitüzött céljuk alacsony volatilitás mellett.

\subsubsection{Alfa Ráta}

Ez az alfejezet az új, még nem elterjedt, nem klasszikus mutatószámok közül az Alfa Rátát és alkalmazását mutatja be az abszolút hozamú alapok értékelése esetében. Ezen befektetési alapok esetén a piaci gyakorlat szerint a benchmark vagy egy kockázatmentes hozam, vagy állampapíroknak egy meghatározott indexe, és ennek meghaladására tesz vállalást a befektetési alap kezelője. Ez a megközelítés ugyanakkor összekeveri a Bétából fakadó és a Jensen-alfából eredő hozamokat. Ennek pedig az az oka, hogy bár a benchmark egy kockázatmentes hozam, a befektetési alap vagy 
portfólió hozamának egy része a Bétához kötődik, mivel az alapkezelő kockázatos eszközökbe is fektet, amik a Bétán keresztül együtt mozognak bizonyos piaci indexekkel. Így helytelen a Jensen-alfákat a kockázatmentes hozamból, mint benchmarkból levezetni, mert a kimutatott Alfák nagyságának egy jelentős hányadát valójában nem az alapkezelő tudása vagy hozzáértése magyarázza, hanem az, hogy az általa választott összetételü portfólió egy kockázatos indexet vagy indexeket követ. Mindezek miatt a befektetési alap vagy portfólió hozamának a megfelelö benchmarkhoz társítható részének az azonosítása nem magától értetődő feladat, és ezért az Információs Ráta számítását is módosítani kell. Így a következőkben bemutatjuk az abszolút hozamú befektetési alapok helyes értékelésére használható új mutatószámot, az Alfa Rátát és annak gyakorlati alkalmazását a szakirodalomban.

\section{Alfa Ráta}

Az előbbiekben tárgyalt problémának az áthidalására az egyik lehetséges megoldás a kockázati faktorokra épülő keret használata. Ezek a faktorok különféle befektetési stílusokat vagy különböző kockázati tényezőket jeleníthetnek meg. Pojarliev és Levich 2013-as cikkükben (Pojarliev és Levich, 2013) a módosított Információs Rátát Alfa Rátának nevezik (IR*):

$$
\text { Alfa Ráta }=\mathrm{IR}^{*}=\frac{\hat{\alpha}}{\sigma_{\widehat{\alpha}}},
$$

ahol

$$
\hat{\alpha}=R_{p}-\sum_{i} \hat{\beta}_{i t} F_{i t}+e_{t}
$$

továbbá $R_{p}$ a befektetési alap/portfólió hozama, $F_{i t}$ a különféle kockázati faktorok/befektetési stílusok, $\beta_{i t}$ a különböző kockázati faktorokra való érzékenysége a befektetési alap/portfólió hozamának.

Pojarliev és Levich (2013) az Alfa Ráta számítására mutattak példát a Deutsche Bank dbSelect adatbázisából származó adatainak felhasználásával a 2005-2010 közötti időszakra vonatkozóan. A dbSelect platformon a Deutsche Banknál olyan menedzselt befektetési számlák találhatóak, amik lehetővé teszik a befektetők számára, hogy 
különféle deviza kereskedők portfólióiba fektessenek. A Deutsche Bank szerint a dbSelect-ben 2013. augusztusi adatok alapján mintegy 5 milliárd USD összeget tartottak a különféle nyugdíjbiztosítók, alapok alapjai, privát bankok, biztosító társaságok és egyéb befektetők.

Pojarliev és Levich (2013) megmutatták, hogy a különféle devizakereskedök Alfa teljesítményét hogyan lehet Béta és Alfa hozamokra bontani. Professzionális devizakereskedök hozamait használták a dbSelect platformról és olyan kockázati faktorokat $\left(F_{i t}\right)$, amik népszerü kereskedési stratégiákat és stílusokat testesítenek meg.

A népszerű stratégiák a következők:

1. Carry trade vagy forward hozamtorzulás: Ez a stratégia azon az általános tendencián alapul, hogy a magasabb kamatlábbal rendelkező devizák általában felértékelődnek.

2. A technikai trendeket követő stratégiák: Ezek a stratégiák a devizák árfolyamainak tartós elmozdulásain alapulnak.

3. Az értékalapú befektetési stratégiák: Ezek a stratégiák a hosszú távú, átlaghoz visszahúzó vásárlóerő-paritáson mért devizaárfolyamokon alapulnak.

Pojarliev és Levich (2013)-nál ezeket a stratégiákat különféle devizaárfolyamokba való befektetést lehetővé tevő indexek, mint faktorok reprezentálják az elemzésükben az Alfa Ráta számításához. Használják továbbá a devizapiaci volatilitást, mint negyedik magyarázó tényezőt:

1. A carry trade faktor helyettesítője a Deutsche Bank G10 Harvest Indexe. Ennek a kereskedhető indexnek a hozama a következő befektetési stratégiának a hozamaként áll elő: A G10 devizauniverzum legnagyobb devizái közül három magas hozamú devizájába történő long befektetésböl, és ezzel párhuzamosan a három alacsony hozamú devizának a shortolásából eredő hozam.

2. A trendkövető faktort az AFX Currency Management Index testesíti meg. Ez az index annak a befektetési stratégiának a hozamát követi, ami hét devizapárba történő befektetésböl áll, ahol a befektetési súlyokat a spot piaci kereskedési 
volumene és a három különböző hosszúságú mozgó átlagon alapuló szabály határozza meg.

3. Az értékalapú kockázati faktor helyettesítője a Deutsche Bank FX PPP Indexe. A Deutsche Bank az elmúlt három havi átlagos napi spot ráta, valamint az OECD évente publikált vásárlóerö-paritáson mért devizaárfolyam hányadosaként készít egy rangsort. Az FX PPP Index azt a hozamot tükrözi, amit G10 devizauniverzumból a Deutsche Bank rangsora alapján a három legmagasabb rangú devizába történő long befektetés, valamint a három legalacsonyabb rangú deviza shortolása eredményez.

4. A volatilitás faktor nem egy kereskedhető stratégia hozamát tükrözi. A szerzők a devizapiacok volatilitásának helyettesítőjeként használják a Deutsche Bank Currency Volatility Indexét. Ez az index a háromhavi súlyozott átlaga a kilenc jelentős devizapár implikált volatilitásának, ahol a súlyokat a BIS felmérések kereskedési volumenei szolgáltatják.

\begin{tabular}{|c|c|c|c|c|c|c|c|c|c|}
\hline & $\begin{array}{l}\text { Többlethozam } \\
(\%)\end{array}$ & Alfa (\%) & $\begin{array}{l}\text { Carry } \\
\text { Béta }\end{array}$ & $\begin{array}{l}\text { Trend } \\
\text { Béta }\end{array}$ & $\begin{array}{l}\text { Érték } \\
\text { Beta }\end{array}$ & $\begin{array}{l}\text { Szórás } \\
\text { Béta }\end{array}$ & $\begin{array}{l}\mathrm{R} \\
\text { négyzet }\end{array}$ & IR & $\begin{array}{l}\text { Alfa } \\
\text { Ráta }\end{array}$ \\
\hline L27 & 4,15 & $\begin{array}{l}2,92 \\
(1,00)\end{array}$ & $\begin{array}{l}1,01 \\
(\mathbf{3 , 4 1})\end{array}$ & $\begin{array}{l}0,70 \\
(\mathbf{2 , 5 6 )}\end{array}$ & $\begin{array}{l}-0,15 \\
(-0,68)\end{array}$ & $\begin{array}{l}-0,06 \\
(-0,22)\end{array}$ & 0,212 & 0,47 & 0,38 \\
\hline L28 & 4,97 & $\begin{array}{l}4,87 \\
(\mathbf{3 , 0 1})\end{array}$ & $\begin{array}{l}-0,14 \\
(-0,89)\end{array}$ & $\begin{array}{l}0,08 \\
(0,56)\end{array}$ & $\begin{array}{l}0,25 \\
(\mathbf{1 , 9 9})\end{array}$ & $\begin{array}{l}-0,18 \\
(-1,00)\end{array}$ & 0,068 & 1,13 & 1,15 \\
\hline
\end{tabular}

Adatok: Nyolcvanhét havi megfigyelés 2006. januártól 2013. márciusig. Zárójelben a t-értékek, a félkövér szedés jelzi a statisztikailag szignifikáns eredményeket 5\%-os szignifikancia szinten.

1. táblázat: Alfa és Béta hozamok két devizabefektető esetében Pojarliev és Levich, 2013 100. oldala alapján.

Mind az L27-es menedzser és mind az L28-as menedzser körülbelül ugyanolyan évesített bruttó többlethozamokat ért el a hétéves megfigyelési időszak alapján (Jensenalfa L27: 4,15\%, L28: 4,97\%). Az Információs Ráták viszont már komoly eltérést mutatnak: L27: 0,47 és L28: 1,13, ami az L27-es menedzser lényegesen magasabb volatilitásából fakad, jelentősen lerontva a kockázatra viszonyított eredményt. Mivel a jutalékok a többlethozam alapján kerülnek meghatározásra, mindkét menedzser körülbelül hasonló teljesítményalapú díjazásban részesülne. 
Az elemzés tisztázza, hogy az L27-es menedzser hozamait meg lehet magyarázni a carry és trend kockázati faktorokkal. Ha figyelembe vesszük az ezen kockázati faktorokra való kitettséget, akkor az L27-es menedzser becsült Alfája 3\% alá esik vissza, és statisztikailag sem lesz szignifikáns az értéke. Az L28-as menedzsernek ezzel szemben egy kis mértékű, de szignifikáns kitettsége van az érték kockázati faktorra, amit a Deutsche Bank FX PPP Index reprezentál. Az L28-as menedzser Alfája 4,87\%, ami majdnem megegyezik a teljes többlethozamának az értékével. Az eredmények azt sugallják, hogy az L28-as menedzser képes magas többlethozam elöállítására azáltal, hogy olyan stratégiákat követ, amiket az elemzett négy kockázati faktor nem reprezentál.

Pojarliev és Levich (2013) az utolsó oszlopban számítják ki az Alfa Ráta értékét, ahol a teljes többlethozam értékeiböl elöször kivonják a Béta kitettségeket, így pontosabban meghatározva az Alfa értékeit, majd kiszámítják az általuk definiált módosított Információs Rátát. Mind a hagyományos Információs Ráta, mind az alternatív Alfa Ráta ugyanarra a következtetésre vezet a szerzők elemzésében: az L28-as menedzser felülteljesíti az L27-es menedzsert.

Pojarliev és Levich (2008) 34 devizába fektető befektetési alap teljesítményét elemezte azonos technika segítségével. A carry trade faktor helyettesítőjeként a Citibank Beta1 G10 Carry Indexét, a trendkövetö faktor helyettesítésére az AFX Currency Management Indexét használták. Az érték faktor helyettesítője a Citibank Betal Purchasing Power Parity Indexe volt, míg a volatilitás helyettesítésére az EUR/USD és USD/JPY árfolyamok egyhavi implikált volatilitását használták.

Az Alfa Ráta átlag és medián értékei kisebbek, mint a hagyományos Információs Ráta esetében. Pojarliev és Levich (2008) az elemzésükben nyolc olyan devizakereskedőt találtak a 34 fös mintából, amelyeknek az Információs Rátája pozitív volt, miközben az Alfa Rátájuk negatív. Ezek az eredmények azt mutatják, hogy ezen devizakereskedők eredményei megmagyarázhatók az elemzett három kockázati faktor felhasználásával, és az nem a menedzserek tehetségéből fakadó többteljesítmény. 


\begin{tabular}{|c|c|c|c|c|c|c|c|}
\hline & $\begin{array}{l}\text { Éves } \\
\text { Átlogs }\end{array}$ & Éves & & & Éyes & & \\
\hline Alapkezelő & Hozam & hozam & Szórás & $I R$ & Alfa & Követési hiba & $I R^{*}$ \\
\hline M1 & 22,0 & 19,34 & 14,71 & 1,31 & 22,13 & 14,57 & 1,52 \\
\hline M2 & 6,4 & 3,70 & 8,62 & 0,74 & $-2,48$ & 4,81 & $-0,52$ \\
\hline M3 & 2,5 & $-0,16$ & 3,00 & $-0,05$ & 0,31 & 2,94 & 0,11 \\
\hline M4 & 5,7 & 2,98 & 5,16 & 0,58 & 2,91 & 4,68 & 0,62 \\
\hline M5 & 5,4 & 2,73 & 8,00 & 0,36 & $-4,19$ & 6,24 & $-0,67$ \\
\hline M6 & 10,7 & 8,00 & 22,51 & 0,36 & $-8,97$ & 15,75 & $-0,57$ \\
\hline M7 & 4,0 & 1,35 & 1,31 & 1,03 & 1,91 & 1,20 & 1,60 \\
\hline M8 & 7,2 & 4,53 & 3,77 & 1,20 & 6,16 & 3,44 & 1,79 \\
\hline M9 & 14,5 & 11,80 & 15,32 & 0,77 & 10,43 & 15,27 & 0,68 \\
\hline M10 & 6,5 & 3,78 & 6,96 & 0,54 & 3,08 & 6,94 & 0,44 \\
\hline M11 & 0,8 & $-1,87$ & 0,94 & $-1,99$ & $-1,86$ & 0,92 & $-2,03$ \\
\hline M12 & 1,4 & $-1,26$ & 12,15 & $-0,10$ & 0,57 & 11,26 & 0,05 \\
\hline M13 & 2,3 & $-0,37$ & 13,83 & $-0,03$ & 0,22 & 10,20 & 0,02 \\
\hline M14 & 8,1 & 5,42 & 29,34 & 0,18 & 13,08 & 27,09 & 0,48 \\
\hline M15 & 5,9 & 3,18 & 11,92 & 0,27 & $-0,26$ & 9,63 & $-0,03$ \\
\hline M16 & 7,7 & 5,04 & 6,39 & 0,79 & 2,67 & 5,90 & 0,45 \\
\hline M17 & 7,1 & 4,43 & 13,73 & 0,32 & $-7,39$ & 11,09 & $-0,67$ \\
\hline M18 & 2,2 & $-0,49$ & 4,03 & $-0,12$ & $-2,21$ & 3,76 & $-0,59$ \\
\hline M19 & 5,0 & 2,27 & 8,04 & 0,28 & 2,84 & 7,84 & 0,36 \\
\hline M20 & 6,2 & 3,52 & 39,21 & 0,09 & 3,27 & 23,87 & 0,14 \\
\hline M21 & 5,9 & 3,24 & 23,98 & 0,13 & $-5,01$ & 15,87 & $-0,32$ \\
\hline M22 & 8,0 & 5,31 & 8,88 & 0,60 & $-0,54$ & 7,68 & $-0,07$ \\
\hline M23 & 9,9 & 7,24 & 11,57 & 0,63 & 7,71 & 11,04 & 0,70 \\
\hline M24 & 2,7 & $-0,02$ & 6,56 & 0,00 & 0,22 & 3,92 & 0,06 \\
\hline M25 & 17,6 & 14,90 & 8,91 & 1,67 & 12,73 & 8,34 & 1,53 \\
\hline M26 & 25,7 & 22,98 & 14,82 & 1,55 & 25,99 & 14,28 & 1,82 \\
\hline M27 & 2,7 & $-0,04$ & 5,89 & $-0,01$ & $-0,42$ & 4,34 & $-0,10$ \\
\hline M28 & 5,7 & 3,02 & 3,86 & 0,78 & 3,51 & 3,79 & 0,93 \\
\hline M29 & 22,7 & 19,97 & 12,74 & 1,57 & 19,53 & 12,14 & 1,61 \\
\hline M30 & 10,0 & 7,27 & 22,39 & 0,32 & 3,32 & 14,42 & 0,23 \\
\hline M31 & 3,7 & 1,02 & 13,90 & 0,07 & $-1,71$ & 8,18 & $-0,21$ \\
\hline M32 & 10,3 & 7,62 & 13,71 & 0,56 & 8,50 & 9,07 & 0,94 \\
\hline M33 & 14,7 & 11,98 & 19,49 & 0,61 & 12,72 & 18,29 & 0,70 \\
\hline M34 & 5,7 & 2,98 & 3,47 & 0,86 & 1,72 & 2,99 & 0,57 \\
\hline Átlag & 8,14 & 5,45 & & 0,47 & 3,84 & & 0,34 \\
\hline Max & 25,70 & 22,98 & & 1,67 & 25,99 & & 1,81 \\
\hline
\end{tabular}




$\begin{array}{lrrrrr}\text { Medián } & 6,30 & 3,61 & 0,45 & 2,29 & 0,29 \\ \text { Min } & 0,80 & -1,87 & -1,99 & -8,97 & -2,02\end{array}$

Megjegyzés: Az adatok 72 havi megfigyelésen alapulnak, az éves átlagos hozam az alap által elért teljes hozam, az éves többlethozamot az alap által elért teljes hozamból a kockázatmentes hozamot levonva kapjuk, az éves Alfa az évesített, faktormodellből becsült alfa együttható befektetési alapkezelönként, a követési hiba az évesített alfa hozamok szórása, $I R$ és $I R^{*}$ a szöveg szerintiek definiált.

2. táblázat: Az egyes devizabefektetők teljesítménye 2001-2006 Pojarliev és Levich (2008) 25. oldal alapján. Saját szerkesztésben félkövéren szedéssel kiemelve azok az esetek, ahol az Információs Ráta pozitív értékből negatívba vált a béta hozamokkal korrigált Alfa Ráta számításakor.

\subsubsection{Manipulációbiztos Teljesítménymutatók}

Ebben az alfejezetben egy szintén új és még nem elterjedt mutatószámot, a Manipulációbiztos Teljesítménymutatókat, és gyakorlati alkalmazásuk szakirodalmát mutatjuk be mutatunk be. Ezen mutatószámok az abszolút hozamú alapok mellett a minden befektetési alap és hedge fund teljesítményének kiértékelését megnehezítő problémára, a teljesítménymanipuláció kérdéskörére kínálnak megoldást. Az értekezésben nem a mikroökonómiában közismert Gibbard-Satterthwaite-tétel (lásd pl. Mas-Colell et al. (1995) 23. fejezet) szerinti manipulációmentességet értjük manipulációbiztosság alatt. Itt ugyanis nem egy társadalmi-választási függvénynek a manipulációval történő sebezhetőséget vizsgáljuk. Ehelyett itt azt szeretnénk biztosítani, hogy az alapkezelő menedzser ne tudja növelni a saját teljesítményalapú javadalmazását, valamint bónuszait azáltal, hogy ismeri az értékelésére használt teljesítménymutatót. Így ne legyen az lehetséges, hogy bár nem rendelkezik semmilyen lényeges többlettudással vagy információval, amire a befektetési döntéseit alapozná, de mivel ismeri az értékelésre használt mutatószám gyengeségeit, ezért képes olyan befektetési döntéseket hozni, amelyek bár nem növelik ténylegesen a befektetési alapot birtokló befektetők hasznosságát, mégis növelik az értékelésre használt mutatószám értékét. Olyan értékelési rendszer alkalmazása a célunk tehát, amely csak azokat a befektetési döntéseket jutalmazza, amelyek ténylegesen növelik a befektetők hasznosságát, amelyeket tehát csak olyan alapkezelő menedzserek képesek 
végrehajtani, akiknek vagy többletinformációi, vagy jobb képességeik vannak a piacnál, és ezekre építve valóban képesek kockázattal korrigált többlet hozamot generálva eltérni a piaci indexet leképező portfólió összetételétöl.

A klasszikus teljesítménymutatókról már bizonyítást nyert (Ingersoll et al. (2007)), hogy léteznek olyan kereskedési és jelentési technikák, amelyekkel növelhetők ugyan a mutatók értékei, de valójában nem növelik a befektetök hozam-kockázat térben értelmezett hasznosságát. A Sharpe-mutató esetében a legkönnyebb szemléltetni ezeket a módszereket, mivel ezen mutató felépítése viszonylag egyszerü: a kockázatmentes hozam feletti többlethozamot viszonyítja a portfolió szórásához.

- Az egyik lehetséges manipuláció az ún. hozamsimitás, amikor hosszabb időszakra széthúzva, kiátlagolva jelenti le az alapkezelő a veszteségeit - például illikvid, ritkán árazódó és nehezen értékelhető eszközeinek a szubjektív kimutatása segítségével (Abdulali (2006)). Így a lejelentett átlagos többlethozam nem változik, viszont a kimutatott szórás csökken, tehát végeredményében látszólag javul a kimutatott kockázattal korrigált teljesítmény.

- Létezik továbbá az ún. dinamikus manipuláció is, amikor például egy, a megfigyelt időszak elején tapasztalt szerencsés nyereség után az alapkezelő azzal védi az elért eredményét, hogy a hátralévő időszakra kockázatmentes befektetésekbe menekül, így a kockázattal korrigált teljesítménye valóban magas lesz, hiszen a szórása közelít majd nullához. Ugyanakkor a választása mégis szuboptimális, és nem biztosítja a legnagyobb hasznosságot a befektetőinek, mert valószínüleg valamilyen arányban a későbbi időszakban is kellene tartania valamennyi kockázatos eszközt. Ingersoll et al. (2007) ezeken túl még bemutat további befektetési stratégiákat is, amelyekben opciókat is felhasznál, és amely stratégiák irreálisan magas Sharpe-ráta-értékeket eredményeznek: Ha például az alapkezelő elad egy 1-hónap lejáratú OTM-opciót az időszak elején, és mind az abból származó összeget, mind a már meglévő eszközeit kockázatmentes eszközbe fekteti, akkor, amennyiben az opció értéktelenül jár le (aminek szigorúan pozitív a valószínüsége), úgy pozitív hozamot ér el nulla szórás mellett, ami végtelen értékü Sharpe-rátát eredményez. A pozitív valószínüség miatt pedig ennek a stratégiának a várható értéke is végtelen Sharpe-rátát ad eredményül. 
Magyarországi befektetési alapkezelökkel folytatott interjúink alapján úgy tünik, hogy az első fajta manipuláció, a hozamsimitás lehetösége a magyar befektetési alapok esetében kevésbé valószinü, mivel a befektetési alapok napi gyakoriságú nettó eszköz értékét szigorú szabályok mentén az alapkezelőtől független letétkezelő végzi, és így inkább csak ingatlan alapok esetén tünik reálisnak effajta manipulációnak a megléte.

Ugyanakkor a második fajta anomália, aminek a szakirodalom a dinamikus manipuláció elnevezést adta viszonylag gyakran elöfordulhat a magyar piacon. Érdemes ugyanakkor megemlíteni, hogy a legtöbb esetben ezek mögött nem tudatos befektetési alapkezelői döntések, nem a teljesítménymérő mutatószámok tudatos kijátszása iránti szándék állhat, hanem egyfajta alapkezelői kockázatkerülési stratégia, ami szuboptimális döntésekhez vezet akkor, ha például az alapkezelő az év első felében már az elvárt mértékben haladta meg a benchmarkhozamot, amitől a bónusza is függ, és ezért az év hátralévő részében „védi” a teljesítményt azzal, hogy kockázatmentes befektetésbe menekül az év hátralévő részére, és ezért több egyébként nyereséggel kecsegtető befektetési lehetőséget is elmulaszt.

A továbbiakban nem teszünk különbséget a kétfajta hozammanipuláció kimutatásának kapcsán, mivel egyik rendelkezésünkre álló statisztikai módszer sem tud pontos magyarázatot adni a feltárt anomáliák hátterére vonatkozóan. Ugyanakkor a fentiek figyelembevétele mellett azt feltételezhetjük, hogy elsősorban az utóbbi, szuboptimális dinamikus manipulációnak a nyomait fogjuk fellelni.

Ingersoll et al. (2007) azt is megmutatták, hogy létezhetnek olyan jól megkonstruált teljesítménymutatók, melyek hasznossági alapú megközelítésből indulva képesek kiküszöbölni a klasszikus teljesítménymutatók manipulálhatóságából eredő problémákat. A manipulációbiztos teljesítménymutatók eredményeit nem lehetséges feljavítani jelentésbeli simításokkal, azaz kiátlagolva lejelentett hozameredményekkel, amelyek az átlaghozamot változatlanul hagyják, míg a szórást csökkentik így összességében látszólag feljavítják a hozam-szórás kombinációt. Ezen túl a manipulációbiztos teljesítménymutatók értékét piaci indexet leképező portfóliótól csak olyan eltéréssel, egyes befektetési elemek felülsúlyozásával lehet növelni, amely befektetési döntések azon alapulnak, hogy az alapkezelő menedzser piachoz viszonyítva 
többletinformációval rendelkezik, vagy a menedzser valós hozzáadott értéket képes létrehozni az időzítési, kiválasztási képességének birtokában.

További elönyük, hogy nem tartozik az előfeltevéseik közé a hozamok normális eloszlása, így kevésbé torzulnak az eredményeik ferde, vagy vastagszélü hozameloszlások esetében szemben a klasszikus teljesítménymutatókkal, amik alapvetően normális eloszlást feltételeznek, és így jobban érzékenyek a valós életben tapasztalt nem-normális eloszlásokból fakadó torzításokra (Ingersoll et al. (2007)).

A klasszikus teljesítménymutatók esetében Ingersoll et al. (2007) mutatták meg, hogy azok egyrészt manipulálhatók, sőt azt is, hogy pontosan hogyan lehet azokat manipulálni.

Ingersoll et al. (2007) a Manipulációbiztos Teljesítménymutatókat (MBTM) az alábbi feltételeken keresztül jellemezték, karakterizálták:

1. Egy egyedi értékszámot kell adnia a rangsoroláshoz.

2. Az elért értékszámnak nem szabad függenie a portfólió pénzben kifejezett értékétől, csak a százalékban mért hozamtól. ${ }^{3}$

3. Informálatlan befektetők nem érhetnek el magasabb becsült értékszámot, ha eltérnek a benchmarktól, az informált befektetők azonban arbitrázs-lehetőségek használata által igen.

4. A mutatószám konzisztens kell, hogy legyen az általános pénzpiaci egyensúlyi feltételekkel.

Ha ezen feltevések közül bármelyik nem teljesül, akkor létezik legalább egy olyan módszer, amellyel aktív portfóliókezelők képesek az értékszámuk javítására, manipulálására olyan stratégiák alkalmazásával, amik látszólag jobb kockázathozamelosztásokhoz vezetnek, de a valóságban úgy érnek el magasabb értékszámot, hogy nincs valós teljesítmény mögötte, nem növelik a befektető hasznosságát.

3 A befektetői hasznosság szempontjából, így a módszertan szempontjából is valóban csak a befektetési alap teljesítménye számít. Ugyanakkor megjegyzendő, hogy az alap mérete hatással van a kezelési költségek és díjak befektetők közötti szétosztására és így fajlagos méretére, valamint a túl kicsi és túl nagy befektetési alapok befektetési lehetőségeire is, így a gyakorlatban visszahat a befektetők költségekkel csökkentett hozamára. 
Az első feltétel kizárja azokat mutatószámokat, amelyek csak részben állítanak fel sorrendet, továbbá az olyan használhatatlan mutatószámokat, mint például amelyek egyszerüen csak az elérhető hozamokat állítják egy listába.

A második feltétel egyszerủen azt mondja ki, hogy a hozamok önmagukban elégséges statisztikák, míg a pénzben mért nyereségek és veszteségek nem. Így például az alap nettó eszközértékének abszolút nagysága, nem lehet mérvadó a rangsorolásban, mivel pusztán azért, mert egyik alap nagyobb vagyontömeggel bír, mint a másik, az még nem jelenti azt, hogy az egyik alap jobban is teljesít, mint a másik.

A harmadik és negyedik feltétel azt foglalja össze, hogy az informálatlan befektetők számára nem lehetséges a benchmarktól való eltérés által profitálni, pl. azzal, hogy megpróbálják megváltoztatni a befektetési alap értékszámát a megfigyelhető adatokon, míg az arbitrázs-lehetőségek kihasználásból eredő többteljesítménynek valóban tükröződnie kell az értékszámban. Tehát például egyszerü hozamsimítással akár kiátlagolt hozamok manipulált lejelentésével, akár egy szerencsés időszak utáni kockázatmentes befektetésre való teljes áttéréssel lecsökkentett volatilitással ne lehessen hozzáadott érték/információ nélkül javítani a mutatószám értékét.

Ugyanakkor, a tényleges hasznosságot növelő befektetési döntéseket a mutatónak ki kell mutatnia, és ezzel összhangban egyre magasabb értékeket kell társítania az ilyen eredményekhez. A szerzők megmutatják, hogy ezek a feltételek akkor teljesülnek, ha a mutatószám:

1. Növekedő a hozamokra (monoton),

2. Konkáv,

3. Időben szeparábilis,

4. Hatványfüggvény formája van.

Az első feltétel azt biztosítja, hogy a mutatószám elismeri az arbitrázs-lehetőségeket. A második feltétel azt akadályozza meg, hogy pusztán a tőkeáttétel növelése, vagy a beárazatlan kockázat hozzáadása által magasabb értékszámot lehessen elérni. Másképpen megfogalmazva nem csak az elért hozam nagysága, hanem a vállalt 
kockázat is számít. A harmadik feltétel a dinamikus, azaz időbeli manipulációt akadályozza meg. A negyedik feltétel biztosítja a konzisztenciát a pénzpiaci egyensúlyelmélettel és azért szükséges a különböző hozamokat a különböző időpontokból venni, hogy a különböző kimenetekből származó hozamokat helyettesítsék.

Az Ingersoll et al. (2007) által javasolt mutató, ami teljesíti a feltételeket, az alábbi:

$$
\widehat{\Theta}=\frac{1}{(1-\rho) \Delta t} \ln \left(\frac{1}{T} \sum_{t=1}^{T}\left[\frac{1+r_{t}}{1+r_{f t}}\right]^{1-\rho}\right),
$$

ahol $\widehat{\Theta}$ a befektetési alap kockázattal korrigált többlethozamára ad becslést. Egy adott Є̂-ra a portfóliónak az értékszáma megegyezik egy kockázatmentes eszköznek a folytonos hozamszámítással számított és évesített hozamával, ami a @̂ értékével haladja meg a kockázatmentes hozamot. $r_{t}$ az alap hozama, $r_{f t}$ a kockázatmentes hozam.

$\rho$ a relatív kockázatelutasítási együttható, aminek az értéke a szakirodalomban megtalálható tapasztalatok alapján általában a 0,2 és 10 közötti tartományba esik: Arrow (1971) alapján az értéke 1 körüli, valamint Szpiro és Outreville (1988) eredményei szerint 1 és 5 közé esik, a hányados átlaga pedig 2,89. Layard et al. (2008) szintén 1 körüli értékeket tapasztalt. Friend és Blume (1975), valamint Kydland és Prescott (1982) tanulmányai szerint 2 körüli, míg Ingersoll et al. (2007) alapján pedig 2 és 4 közötti tartományba esik. Gandelman és Hernandez-Murillo (2015) szerint országonként eltérő értéket mutat, 1 körüli jellemző értékkel, és az átlagtól jelentősen eltérő országok értékei is beleférnek a 0-3 tartományba.

Mind Ingersoll et al. (2007) és Brown et al. (2010) 2 és 4 közé eső relatív kockázatelutasítási együtthatókkal számolt. Ingersoll et al. (2007) azzal indokolta ezt az alkalmazott tartományt, hogy bár elvileg lehetséges lenne ennél szélesebb intervallummal is számolni a tapasztalatok szerint, ám a 2 és 4 közé eső relatív kockázatelutasítási együttható olyan portfólióknak felel meg, amelyeknek a tőkeáttétele 1,75 és 0,75 közé esik. Ez a tartomány pedig felöleli a legtöbb rangsorolni kívánt alapot. Brown et al. (2010) az Ingersoll et al. (2007) eredményeivel való összevethetőség miatt döntött a 2 és 4 közé eső kockázatelutasítási együtthatók használata mellett. Az 
összevethetőség miatt mi is 2 és 4 közé eső kockázatelutasítási együtthatókkal fogunk számolni a későbbiekben.

Az MBTM-et a bechmark index-szel is azonosíthatjuk. Az informálatlan befektetők számára a benchmarknak kívánatos, ideális befektetési célpontnak kell lennie magas értékszámmal. Ha a benchmarknak a lognormális hozama $1+\mathrm{rb}$, akkor a $\rho$ paraméter a következő (lsd. Ingersoll et al. (2007)):

$$
\frac{\ln \left[E\left(1+r_{b}\right)\right]-\ln \left(1+r_{f}\right)}{\operatorname{Var}\left[\ln \left(1+r_{b}\right)\right]}
$$

Ingersoll et al. (2007) összehasonlítja az általuk javasolt MBTM-et más teljesítménymérő mutatószámokkal. Három kockázatelutasítási együtthatóra számították ki a különbséget a piaci portfólióra és különféle portfóliókra. A kockázatmentes hozam $5 \%$ volt, a piaci prémium $12 \%$, míg a szórás $20 \%$, ami konzisztens a $\rho=3$ paraméterrel.

Az MBTM szerint a manipulált portfóliók teljesítménye elmarad a piaci portfólióétól (lásd 3. táblázatot). A Sharpe-mutató alapján manipulált portfólió Sharpe-rátája az esetek 82,6\%-ban haladta meg a piaci portfólió értékét, míg 5\%-os konfidenciaszinten az esetek 20,4\%-ban volt felülteljesítő a piachoz viszonyítva Sharpe-rátában mérve. Ezzel szemben a portfólió valójában csak az esetek 46,3\%-ában verte meg a piaci portfóliót MBTM-alapon mérve, és szignifikánsan csak az esetek 0,2\%-ában volt jobb. Továbbá az esetek 1,4\%-ban szignifikánsan teljesített alul Sharpe-rátában mérve, míg az MBTM szerint mérve valójában az esetek 9,1\%-ában. 


\begin{tabular}{|c|c|c|c|c|c|c|c|c|c|c|c|c|}
\hline \multirow[b]{3}{*}{$\begin{array}{l}\text { A } \\
\text { mutatószám, } \\
\text { aminek } \\
\text { megfelelően } \\
\text { manipulálták } \\
\text { a portfoliót }\end{array}$} & \multirow{2}{*}{\multicolumn{3}{|c|}{$\begin{array}{l}\text { Saját mutatószám } \\
\text { szerinti érték }\end{array}$}} & \multicolumn{9}{|c|}{$\begin{array}{l}\text { A Manipulációbiztos Mutatószám } \\
\text { (MBTM } \theta \text { ) szerinti rangsorolás }\end{array}$} \\
\hline & & & & MB & $\Gamma \mathrm{M} \theta(\rho=$ & $=2)$ & MB1 & TM $\theta($ & $\rho=3)$ & MB] & $\Gamma \mathrm{M} \theta(\rho=$ & $=4)$ \\
\hline & $\begin{array}{l}\text { Nyeré } \\
\text { gyak. } \\
\text { k } \%)\end{array}$ & $\begin{array}{l}\text { Gyak. } \\
\text { szignif } \\
+(\%)\end{array}$ & $\begin{array}{l}\text { Gyak. } \\
\text { if. zsignif. } \\
-(\%)\end{array}$ & $\begin{array}{c}\text { Átlag } \\
\theta \text { portf- } \\
\theta \text { mkt } \\
(\%)\end{array}$ & $\begin{array}{c}\text { Gyak } \\
\text { portf }> \\
\theta \text { piac } \\
(\%)\end{array}$ & $\begin{array}{l}\text { Gyak } \\
\text { szignif } \\
+/-(\%)\end{array}$ & $\begin{array}{c}\text { Átlag } \\
\theta \text { portf- } \\
\theta \text { mkt } \\
(\%)\end{array}$ & $\begin{array}{c}\text { Gyak } \\
\theta \\
\text { portf } \\
> \\
\theta \text { piac } \\
(\%)\end{array}$ & $\begin{array}{l}\text { Gyak } \\
\text { szignif } \\
+/-(\%)\end{array}$ & $\begin{array}{c}\text { Átlag } \\
\theta \text { portf- } \\
\theta \text { mkt } \\
(\%)\end{array}$ & $\begin{array}{c}\text { Gyak } \\
\theta \text { portf }> \\
\theta \text { piac } \\
(\%)\end{array}$ & $\begin{array}{l}\text { Gyak } \\
\text { szignif } \\
+/-(\%)\end{array}$ \\
\hline Sharpe $S$ & 82,6 & 20,4 & 1,4 & & & & & & & & & \\
\hline Alpha $\alpha$ & 92,4 & 37,6 & 0,2 & $-0,84$ & 46,3 & 0,2 & $-0,96$ & 46,3 & 0,4 & $-1,08$ & 46,0 & 0,5 \\
\hline Gen $\alpha^{g e n}$ & 90,6 & 34,0 & 0,3 & & & 9,1 & & & 9,6 & & & 9,9 \\
\hline Sortino $D$ & 83,6 & 16,6 & 1,6 & $-1,14$ & 42,0 & $\begin{array}{l}0,6 \\
9,9\end{array}$ & $-1,04$ & 42,9 & $\begin{array}{l}1,0 \\
9,7\end{array}$ & $-0,92$ & 44,9 & $\begin{array}{l}1,3 \\
8,9\end{array}$ \\
\hline $\operatorname{SVP} U$ & 83,3 & 20,0 & 2,9 & $-1,00$ & 46,5 & $\begin{array}{c}0,5 \\
10,3\end{array}$ & $-0,87$ & 48,1 & $\begin{array}{l}0,9 \\
9,9\end{array}$ & $-0,74$ & 49,7 & $\begin{array}{l}1,4 \\
9,2\end{array}$ \\
\hline $\begin{array}{l}\text { HM érték } \\
\mathrm{V}_{\text {нм }}\end{array}$ & 71,0 & 14,0 & 2,2 & $-0,62$ & 45,4 & 3,1 & $-1,26$ & 38,5 & 2,4 & $-1,91$ & 33,6 & 1,7 \\
\hline $\begin{array}{l}\text { TM érték } \\
V_{\mathrm{TM}}\end{array}$ & 70,6 & 13,7 & 2,2 & & & 6,9 & & & 9,2 & & & 11,6 \\
\hline
\end{tabular}

3. táblázat: A manipulációbiztos teljesítménymutató Ingersoll et al. (2007) 1532. oldal alapján.

\subsubsection{A manipulált teljesítmény feltárása az MBTM-ek segítségével}

Ez az alfejezet azt mutatja be, hogy az MBTM segítségével miként lehetséges a teljesítménymanipulálás kimutatása, valamint, hogy ezen módszerek alkalmazása milyen gyakorlati eredményekre vezetett az irodalom alapján. Brown et al. (2010) alternatív formában, az Ingersoll et al. (2007)- féle MBTM lineáris közelítését írta fel, amely egyszerüsítés lehetővé tette az úgynevezett Kételkedési Hányados (Doubt Ratio - DR) egyszerű felírását, amely különböző kockázatelutasítási együtthatókkal számolt mutatóértékekből következtet az implikált kockázatelutasítás alakulására. Amikor a Kételkedési Hányados extrém változásokat mutat ki az implikált kockázatelutasításban, akkor nagy valószínüséggel manipuláció áll a háttérben. Ezt az összefüggést sikerült az empirikus adataikon is kimutatniuk, alternatív statisztikai módszerek alkalmazásával, amelyek egyéb megközelítéssel mutatták ki a jelentésbeli vagy hozammanipulációt. A 
szerzők mindezekből azt a következtetést vonták le, hogy a Kételkedési Hányados segítségével is megbízhatóan azonosíthatók a hozammanipulációk.

Brown et al. (2010) az (14) MBTM következő egyszerüsítését, közelítését használták:

$$
\widehat{\Theta}(\rho)=\frac{1}{\Delta t}\left\{\bar{x}+\frac{1-\rho}{2}\left(s_{x}^{*}\right)^{2}\right\},
$$

ahol $\bar{x}$ a többlethozam átlaga és $\left(s_{x}^{*}\right)^{2}=s_{x}^{2}(T-1) / T$ a többlethozam mintából számított varianciája, $\rho$ pedig a relatív kockázatelutasítási együttható.

Brown et al. (2010) hedge fund adatokon tesztelte az MBTM általuk felírt verzióját és az eredményeit összevetette más teljesítménymérő mutatószámokkal, hogy felfedje a manipuláció hatását az alapok jelentett hozamaiban. A lejelentett hozamok kisimítása lehet a legáltalánosabb módja az alapok teljesítményének manipulálására, mivel csökkenteni képes a hozamok volatilitását, miközben az átlaghozamot változatlanul hagyja. Javíthatja a Sharpe-ráta értékét, de az MBTM értékét nem, mivel az a többlet hozam átlagának és varianciájának különbségére épül.

A szerzők 1710 olyan hedge fund hozamait vizsgálták, amelyek túlélték a 2007-es válságot, így 73530 havi hozamot vizsgáltak meg 2004. január és 2007. július között a TASS adatbázisból (Lipper Tradig Advisor Selection System, amely hedge fundok havi adatait tartalmazza) ${ }^{4}$.

A szerzők öt különböző statisztikai módszert használtak az alapok hozamaiban található manipuláció nyomainak feltárására. Az eredmény manipuláció nyomait mutatja. Elméletileg, ha a klasszikus teljesítménymérő mutatószámok manipulálhatóak, míg az MBTM-ek nem, akkor a rangkorrelációnak a klasszikus mutatószámok között magasnak kell lennie (mivel a klasszikus mutatószámok hasonlóan torzulnak a manipulációk hatására), míg köztük és a különböző kockázatelutasítási együtthatóval számított MBTM-ek között alacsonynak. Amint a 4. táblázatban látható ez a feltevés teljesül a mintára, mivel a rangkorreláció a hagyományos mértékek között 0,9 fölötti (lásd például az első oszlop első 8 sorában a Sharpe-ráta rangkorrelációit a klasszikus mértékekkel), míg köztük és az MBTM-ek

\footnotetext{
${ }^{4}$ A megfigyelt hedge fund-ok hozamai ferdék és vastag szélü eloszlással rendelkeznek.
} 
között 0,7 körüli (lásd például 4. táblázatban az utolsó sor első 9 oszlopában a 3-as kockázati elutasítási együtthatóval számolt MBTM - MBTM3-mal jelölve rangkorrelációit a klasszikus mértékekkel).

\begin{tabular}{|c|c|c|c|c|c|c|c|c|c|c|c|}
\hline $\begin{array}{l}\text { Teljesítmény } \\
\text {-mérő } \\
\text { Mutató }\end{array}$ & Sharpe & Omega & Sortino & Kappa & Calmar & Sterling & Berke & $\begin{array}{l}\text { ER on } \\
\text { VaR }\end{array}$ & M Sharpe & $\begin{array}{l}\text { MBTM } \\
1\end{array}$ & $\begin{array}{l}\text { MBTM } \\
2\end{array}$ \\
\hline Omega & 0,9857 & & & & & & & & & & \\
\hline Sortino & 0,9796 & 0,9892 & & & & & & & & & \\
\hline Kappa & 0,9701 & 0,9761 & 0,9969 & & & & & & & & \\
\hline Calmar & 0,9400 & 0,9398 & 0,9736 & 0,9869 & & & & & & & \\
\hline Sterling & 0,9030 & 0,9070 & 0,9164 & 0,9118 & 0,8846 & & & & & & \\
\hline Berke & 0,9681 & 0,9745 & 0,9928 & 0,9938 & 0,9761 & 0,9228 & & & & & \\
\hline ERonVaR & 0,9697 & 0,9532 & 0,9441 & 0,9333 & 0,9016 & 0,9282 & 0,9440 & & & & \\
\hline M.Sharpe & 0,8675 & 0,8623 & 0,8655 & 0,8591 & 0,8314 & 0,9379 & 0,8683 & 0,8948 & & & \\
\hline MBTM1 & 0,6895 & 0,6837 & 0,6991 & 0,7027 & 0,6999 & 0,6151 & 0,6481 & 0,6181 & 0,5788 & & \\
\hline MBTM2 & 0,7259 & 0,7177 & 0,7317 & 0,7344 & 0,7291 & 0,6478 & 0,6825 & 0,6571 & 0,6139 & 0,9872 & \\
\hline MBTM3 & 0,7545 & 0,7444 & 0,7570 & 0,7588 & 0,7513 & 0,6733 & 0,7092 & 0,6876 & 0,6409 & 0,9747 & 0,9960 \\
\hline
\end{tabular}

4. táblázat: Rangkorrelációk a klasszikus és a manipulációbiztos teljesítménymutatók között (az eredeti hozamokon tesztelve) Brown et al. (2010) 49. oldal alapján.

Kontrollmintaként a szerzők torzításmentes replikált hozamokat számítottak az elemzett alapokra Hasanhodzic és Lo (2007) lineáris faktor modelljének felhasználásával (lásd 5. táblázat).

\begin{tabular}{|c|c|c|c|c|c|c|c|c|c|c|}
\hline \multicolumn{8}{|c|}{ Teljesítmény } & \multirow{2}{*}{$\begin{array}{l}\text { ER on } \\
\text { VaR }\end{array}$} & \multirow{2}{*}{ M.Sharpe } & МВТМ МВТМ \\
\hline $\begin{array}{l}\text {-mérő } \\
\text { Mutató }\end{array}$ & Sharpe & Omega & Sortino & Kappa & Calmar & Sterling & Berke & & & 2 \\
\hline Omega & 0,9998 & & & & & & & & & \\
\hline Sortino & 0,9997 & 0,9995 & & & & & & & & \\
\hline Kappa & 0,9992 & 0,9988 & 0,9998 & & & & & & & \\
\hline Calmar & 0,9969 & 0,9963 & 0,9979 & 0,9987 & & & & & & \\
\hline Sterling & 0,9989 & 0,9983 & 0,9994 & 0,9996 & 0,9977 & & & & & \\
\hline Berke & 0,9987 & 0,9981 & 0,9994 & 0,9997 & 0,9985 & 0,9999 & & & & \\
\hline ER on VaR & 0,9997 & 0,9993 & 0,9994 & 0,9990 & 0,9970 & 0,9991 & 0,9990 & & & \\
\hline M.Sharpe & 0,9990 & 0,9988 & 0,9996 & 0,9997 & 0,9982 & 0,9996 & 0,9997 & 0,9992 & & \\
\hline MBTM1 & 0,9652 & 0,9662 & 0,9651 & 0,9640 & 0,9606 & 0,9610 & 0,9606 & 0,9612 & 0,9616 & \\
\hline MBTM2 & 0,9541 & 0,9548 & 0,9542 & 0,9535 & 0,9508 & 0,9504 & 0,9503 & 0,9505 & $0,9512 \quad 0,9883$ & \\
\hline MBTM3 & 0,9277 & 0,9279 & 0,9282 & 0,9279 & 0,9260 & 0,9251 & 0,9254 & 0,9251 & $0,92590,9655$ & 0,9868 \\
\hline
\end{tabular}

5. táblázat: Rangkorrelációk a klasszikus és a manipulációbiztos teljesítménymutatók között (a replikált hozamokon tesztelve) Brown et al. (2010) 50. oldal alapján. 
A várakozásoknak megfelelően a rangkorreláció az alkalmazott MBTM és a klasszikus teljesítménymérő mutatószámok között magas ebben az esetben, mivel definíció szerint nincs manipuláció a hozamokban azok konstrukciójának megfelelően.

A 6. táblázat összehasonlítja a rangkorrelációt a Sharpe-ráta és az MBTM között a különféle alapkategóriákba sorolt alapok esetében, amelyeket az öt alternatív statisztikai módszer manipulációmentesnek (lásd Nem kimutatott sorok), illetve manipuláltnak (lásd Kimutatott sorok) érzékelt. Az öt alternatív módszer: Hasanhodzic és Lo (2007) hedge fund hozam replikáló technikája, Bollen és Pool (2009) Diszkontinuitás-elemzése a 0 körüli hozamokra normális eloszlást használva, Abdulali (2006) Torzítási Rátája, ami a jelentett hozamok aszimmetriáját méri, Bollen és Pool (2008) feltételes autokorrelációja, és Treynor és Mazuy (1966) piaci időzítése. A rangkorrelációk a várakozásoknak megfelelően alacsonyabbak a manipulált alapok esetében általánosságban.

\begin{tabular}{|c|c|c|c|c|c|c|c|c|c|c|c|}
\hline & $\begin{array}{l}\text { Alap } \\
\text { Stílus }\end{array}$ & $\begin{array}{l}\text { Átváltható } \\
\text { Kötvény } \\
\text { Arbitrázs }\end{array}$ & $\begin{array}{l}\text { Fejlődő } \\
\text { Piacok }\end{array}$ & $\begin{array}{l}\text { Részvény- } \\
\text { piac } \\
\text { Semleges }\end{array}$ & $\begin{array}{l}\text { Esemény } \\
\text { Vezérelt }\end{array}$ & $\begin{array}{l}\text { Kötvény } \\
\text { Arbitrázs }\end{array}$ & $\begin{array}{l}\text { Alapok } \\
\text { alapja }\end{array}$ & $\begin{array}{l}\text { Globáli } \\
\text { Makró }\end{array}$ & $\begin{array}{l}\text { Long/ } \\
\text { s Short } \\
\text { Rész- } \\
\text { vény }\end{array}$ & $\begin{array}{l}\text { Mene } \\
\text { dzselt } \\
\text { Határ- } \\
\text { idős }\end{array}$ & $\begin{array}{l}\text { Multi- } \\
\text {-stratégia }\end{array}$ \\
\hline \multirow{4}{*}{$\begin{array}{l}\text { Mind- } \\
\text { összesen }\end{array}$} & MBTMl & 0,905 & 0,244 & 0,854 & 0,456 & 0,702 & 0,655 & 0,906 & 0,735 & 0,932 & 0,659 \\
\hline & MBTM2 & 0,913 & 0,283 & 0,865 & 0,476 & 0,721 & 0,682 & 0,929 & 0,775 & 0,861 & 0,706 \\
\hline & МВТM3 & 0,916 & 0,347 & 0,869 & 0,496 & 0,728 & 0,703 & 0,943 & 0,806 & 0,820 & 0,731 \\
\hline & $\mathrm{N}$ & 38 & 98 & 65 & 135 & 55 & 531 & 53 & 489 & 125 & 121 \\
\hline \multirow{4}{*}{$\begin{array}{l}\text { Nem } \\
\text { kimutatott } \\
(\mathrm{N}=1,316)\end{array}$} & MBTMl & 0,962 & 0,359 & 0,913 & 0,498 & 0,746 & 0,700 & 0,936 & 0,761 & 0,945 & 0,721 \\
\hline & MBTM2 & 0,970 & 0,386 & 0,925 & 0,522 & 0,762 & 0,731 & 0,953 & 0,802 & 0,864 & 0,765 \\
\hline & MBTM3 & 0,973 & 0,439 & 0,929 & 0,541 & 0,768 & 0,752 & 0,958 & 0,833 & 0,816 & 0,791 \\
\hline & $\mathrm{N}$ & 22 & 77 & 57 & 92 & 45 & 403 & 42 & 392 & 104 & 82 \\
\hline \multirow{4}{*}{$\begin{array}{l}\text { Kimutatott } \\
(\mathrm{N}=394)\end{array}$} & MBTMl & 0,721 & $-0,243$ & 0,714 & 0,497 & $-0,103$ & 0,654 & 0,764 & 0,593 & 0,832 & 0,631 \\
\hline & tMBTM2 & 0,753 & $-0,129$ & 0,714 & 0,511 & $-0,103$ & 0,666 & 0,800 & 0,623 & 0,797 & 0,638 \\
\hline & MBTM3 & 0,753 & $-0,094$ & 0,714 & 0,530 & $-0,103$ & 0,676 & 0,827 & 0,654 & 0,842 & 0,641 \\
\hline & $\mathrm{N}$ & 16 & 21 & 8 & 43 & 10 & 128 & 11 & 97 & 21 & 39 \\
\hline
\end{tabular}

\section{6. táblázat: Rangkorreláció a Sharpe-ráta és az MBTM között befektetésistílus szerinti} csoportosításban Brown et al. (2010) 56. oldal alapján. 
Az MBTM-nek a Brown et al. (2010) -féle verziója lehetővé teszi az implikált kockázatelutasítási együttható egyszerü számítását, amelyet a szerzők Kételkedési Hányadosnak (Doubt Ratio - DR) neveztek el :

$$
\text { Kételkedési Hányados }=\mathrm{DR}=\frac{\widehat{\Theta}(2)}{\widehat{\Theta}(2)-\widehat{\Theta}(3)}+2 \approx \frac{2 \bar{x}}{\left(s_{x}^{*}\right)^{2}}+1 \text {. }
$$

Ha a Kételkedési Hányados értéke extrém magas, akkor az extrém kockázatelutasítást jelez, ami a lehetséges teljesítmény manipulálás jele. Brown et al. (2010) 58. oldal, 11. táblázat alapján a 150-nél nagyobb Kételkedési Hányadossal rendelkező alapok 80\%-át az alternatív módszerek is manipuláltnak találták.

A Kételkedési Hányados alsó és felső kvartiliseinek értékei a teljes mintára vetítve valamivel magasabbak, mint az öt alternatív módszer által nem manipuláltnak minősített alapok esetében. A manipuláltnak érzékelt alapok esetében a Kételkedési Hányados értékek sokkal nagyobb intervallumban szóródnak, mint a nem manipuláltnak minősített alapok esetében. Ugyanakkor a globális makró, long/short fedezett részvény és a menedzselt határidős csoportjai nagyon alacsony Kételkedési Hányados értékeket mutatnak mind a manipuláltnak jelzett (Brown et al. (2010) tíz kategóriába sorolta befektetési stílus és stratégia alapján a hedge fund-okat), mind a manipulálatlannak minősített alapok esetében (lásd 7. táblázat). 


\begin{tabular}{|c|c|c|c|c|c|c|c|c|}
\hline \multirow[t]{2}{*}{ Stílus } & & $\mathrm{N}$ & Átlag & Mediá & $\mathrm{Q} 1$ & Q3 & Min. & Max. \\
\hline & \multicolumn{8}{|l|}{ Átváltható Kötvény } \\
\hline \multirow{12}{*}{$\begin{array}{l}\text { Mind- } \\
\text { összesen }\end{array}$} & Arbitrázs & 38 & 45,7 & 32,1 & 2,4 & 70,2 & $-14,7$ & 190,6 \\
\hline & Fejlődő Piacok & 98 & 45,7 & 28,5 & 14,9 & 52,6 & 6,6 & 334,9 \\
\hline & Részvénypiaci Semleges & 65 & 431,4 & 43,1 & 21,4 & 69,1 & $-82,3$ & 12892,6 \\
\hline & Esemény Vezérelt & 135 & 87,8 & 66,1 & 37,4 & 134,0 & 8,8 & 257,6 \\
\hline & Kötvény Arbitrázs & 55 & 77,3 & 59,4 & 18,6 & 99,8 & $-38,9$ & 404,2 \\
\hline & Alapok Alapja & 531 & 70,9 & 55,5 & 32,8 & 93,2 & $-11,8$ & 708,8 \\
\hline & Globális Makró & 53 & 21,0 & 17,6 & 3,8 & 31,6 & $-13,1$ & 79,6 \\
\hline & Long/Short Fedezett & & & & & & & \\
\hline & Részvény & 489 & 24,3 & 25,1 & 13,5 & 39,9 & $-3850,9$ & 719,6 \\
\hline & Menedzselt Határidős & 125 & 5,1 & 2,4 & $-0,9$ & 7,0 & $-59,8$ & 129,7 \\
\hline & Multistratégia & 121 & 57,4 & 32,3 & 14,5 & 90,9 & $-23,2$ & 385,2 \\
\hline & Mindösszesen & 1710 & 63,5 & 35,1 & 14,9 & 66,1 & $-3850,9$ & 12892,6 \\
\hline \multirow{7}{*}{ Nem } & Átváltható Kötvény & & & & & & & \\
\hline & Arbitrázs & 22 & 22,1 & 11,3 & $-4,8$ & 33,3 & $-14,7$ & 130,1 \\
\hline & Fejlődő Piacok & 77 & 39,2 & 23,9 & 14,7 & 40,2 & 6,6 & 334,9 \\
\hline & Részvénypiaci Semleges & 57 & 37,4 & 40,1 & 19,3 & 51,4 & $-82,3$ & 115,7 \\
\hline & Esemény Vezérelt & 92 & 70,6 & 50,0 & 34,1 & 103,0 & 12,3 & 218,2 \\
\hline & Kötvény Arbitrázs & 45 & 58,4 & 36,8 & 12,1 & 74,6 & $-38,9$ & 314,9 \\
\hline & Alapok Alapja & 403 & 55,2 & 47,7 & 29,7 & 74,8 & $-11,8$ & 179,0 \\
\hline \multirow[t]{12}{*}{ Kimutatott } & Globális Makró & 42 & 20,2 & 17,2 & 3,7 & 30,5 & $-7,5$ & 79,5 \\
\hline & Long/Short Fedezett & & & & & & & \\
\hline & Részvény & 392 & 19,5 & 23,1 & 11,7 & 37,4 & $-3850,9$ & 719,6 \\
\hline & Menedzselt Határidős & 104 & 3,2 & 2,4 & $-0,8$ & 6,5 & $-59,8$ & 66,5 \\
\hline & Multistratégia & 82 & 40,1 & 23,5 & 13,4 & 50,0 & $-5,1$ & 227,7 \\
\hline & Mindösszesen & 1316 & 37,3 & 30,5 & 13,0 & 55,2 & $-3850,9$ & 719,6 \\
\hline & Átváltható Kötvény & & & & & & & 100 \\
\hline & Arbitrázs & 16 & 78,2 & 70,0 & 46,6 & 115,4 & $-10,6$ & 190,6 \\
\hline & Fejlődő Piacok & 21 & 69,5 & 36,6 & 25,7 & 86,7 & 14,4 & 254,0 \\
\hline & Részvénypiaci Semleges & 8 & 3238,5 & 133,8 & 98,9 & 6263,4 & 23,3 & 12892,6 \\
\hline & Esemény Vezérelt & 43 & 124,6 & 134,0 & 65,2 & 170,7 & 8,8 & 257,6 \\
\hline & Kötvény Arbitrázs & 10 & 162,2 & 105,8 & 64,3 & 229,4 & 47,3 & 404,2 \\
\hline \multirow[t]{7}{*}{ Kimutatott } & Alapok Alapja & 128 & 120,6 & 93,4 & 50,4 & 151,9 & $-6,9$ & 708,8 \\
\hline & Globális Makró & 11 & 23,7 & 23,0 & 6,7 & 38,8 & $-13,1$ & 63,6 \\
\hline & Long/Short Fedezett & & & & & & & \\
\hline & Részvény & 97 & 43,5 & 35,0 & 19,1 & 55,5 & $-6,3$ & 286,8 \\
\hline & Menedzselt Határidős & 21 & 14,4 & 2,6 & $-4,2$ & 17,3 & $-15,4$ & 129,7 \\
\hline & Multistratégia & 39 & 93,8 & 97,2 & 29,7 & 121,1 & $-23,2$ & 385,2 \\
\hline & Mindösszesen & 394 & 151,0 & 62,7 & 26,8 & 129,4 & $-23,2$ & 12892,6 \\
\hline
\end{tabular}

A Kételkedési Hányados kiszámítható két különböző kockázatelutasítási együtthatóval számított MBTM hányadosaként, $D R$ $=\Theta(2) /(\Theta(2)-\Theta(3))+2$. Az összes alapra nézve a Q1 és Q3 kvartilisek 14,9 és 66,1 között szóródnak, míg a nem kimutatott alapok valamivel alacsonyabban 13,0 és 55.2 között, ugyanakkor a kimutatott alapok sokkal szélesebb sávval bírnak, mint a nem kimutatott alapok, a Q3 kvartilis értéke majdnem a háromszorosa a nem kimutatott alapokénak 129,4-gyel.

7. táblázat: A Kételkedési Hányadosok összehasonítása az alternatív módszerek szerinti manipuláltság alapján csoportosítva Brown et al. (2010) 57. oldal alapján. 
Az eredmények szerint 34 alapnak a Kételkedési Hányadosa 150 fölötti 5\%-os szignifikancia szint mellett, ami a teljes tesztelt mintának a 2\%-a ${ }^{5}$. Ennek a 34 alapnak a $80 \%$-a gyanúsnak lett értékelve az alternatív öt statisztikai módszer segítségével is, tehát a Kételkedési Hányadossal végzett elemzés konzisztens a többi manipulációt jelző statisztikai módszerrel, és egy extrém magas Kételkedési Hányados jó indikátora a lehetséges teljesítménymanipulálásnak, vagy hozamsimításnak (lásd 8. táblázat).

\begin{tabular}{|c|c|c|c|c|c|c|c|}
\hline \multirow{2}{*}{ Stílus } & \multicolumn{3}{|c|}{ Nem Kimutatott } & \multicolumn{3}{|c|}{ Kimutatott } & \multirow{2}{*}{ Mindösszesen } \\
\hline & $<1 \%$ & $<5 \%$ & $\%$ & $<1 \%$ & $<5 \%$ & $\%$ & \\
\hline Átalakítható Arbitrázs & 0 & 0 & $0,0 \%$ & 0 & 0 & $0,0 \%$ & 38 \\
\hline Fejlődő Piacok & 1 & 1 & $1,0 \%$ & 2 & 2 & $2,0 \%$ & 98 \\
\hline Részvénypiaci Semleges & 0 & 0 & $0,0 \%$ & 3 & 3 & $4,6 \%$ & 65 \\
\hline Esemény Vezérelt & 0 & 2 & $1,5 \%$ & 2 & 5 & $3,7 \%$ & 135 \\
\hline Kötvény Arbitrázs & 1 & 1 & $1,8 \%$ & 0 & 2 & $3,6 \%$ & 55 \\
\hline Alapok Alapja & 0 & 0 & $0,0 \%$ & 9 & 11 & $2,1 \%$ & 531 \\
\hline Globális Makró & 0 & 0 & $0,0 \%$ & 0 & 0 & $0,0 \%$ & 53 \\
\hline Long/Short Fedezett & 1 & 1 & $0,2 \%$ & 0 & 1 & $0,2 \%$ & 489 \\
\hline \multicolumn{8}{|l|}{ Részvény } \\
\hline Menedzselt Határidős & 0 & 0 & $0,0 \%$ & 0 & 0 & $0,0 \%$ & 125 \\
\hline Multistratégia & 1 & 2 & $1,7 \%$ & 1 & 3 & $2,5 \%$ & 121 \\
\hline Mindösszesen & 4 & 7 & $0,4 \%$ & 17 & 27 & $1,6 \%$ & 1710 \\
\hline
\end{tabular}

Ez a táblázat megmutatja, hogy hány befektetési alap található befektetési stílusonként 150-nél szignifikánsan magasabb Kételkedési Hányadossal. 5\%-os szignifikancia szinten 34 alapot találunk a teljes mintából 150-nél nagyobb Kételkedési Hányadossal, amely körülbelül a vizsgált alapok 2\%-a. A 34 kimutatott alap 80\%-át az alternatív módszerek is gyanúsnak minősítették, így a Kételkedési Hányados elemzése konzisztens más módszerekkel és egy extrém magas Kételkedési Hányados a gyanús alapok indikátora lehet. Az átalakítható arbitrázs, globális makró és a long/short fedezett részvény, valamint menedzselt határidős csoportok nagyon kevés gyanús alapot tartalmaznak a Kételkedési Hányados szerint, amely azt jelzi, hogy ezek a befektetési stílusok kisebb valószínűséggel vannak kitéve manipulálásnak. Más befektetési stílusok relatíve jobban ki vannak téve manipulációnak: a fejlődő piacok, a részvénypiaci semleges, esemény vezérelt, kötvény arbitrázs, alapok alapja és multistratégia alapok esetében 2-5,4\% a gyanús alapok aránya a kategóriájukon belül, különösen a részvénypiaci semleges, az esemény vezérelt, fix jövedelmű arbitrázs és a multistratégia esetén magas, 4\%-ot meghaladó a gyanús alapok aránya. Kettő részvénypiaci neutrális alap esetében 12 000-nél is magasabb Kételkedési Hányados értékeket találunk.

8. táblázat: Az extrém magas Kételkedési Hányadossal rendelkező alapok Brown et al. (2010) 58. oldal alapján.

${ }^{5}$ Megjegyzendő, hogy az alacsonyabb szórású hedge fund típusoknál is gyakran előfordulnak 150nél magasabb Kételkedési Hányadosok. 


\subsubsection{A manipulált teljesítmény, hozamsimítás feltárásának alternatív módjai: Torzítási Ráta, Diszkontinuitás-elemzés}

Míg a Kételkedési Hányados az implikált kockázatelutasítási együttható változásait méri az MBTM értékeiből kiindulva, addig léteznek egyéb olyan technikák is, amelyek a hozameloszlás sajátosságaiból, és/vagy a hozamok 0-körüli eloszlásából következtetnek a potenciálisan meglévő hozamsimításra, vagy egyéb manipulációra. Ez az alfejezet a hozammanipuláció feltárásának alternatív módjait és alkalmazásukat, a Torzítási Rátát, valamint a Diszkontinuitás-elemzést mutatja be a szakirodalom alapján.

Abdulali (2006) vezette be a Torzítási Ráta (Bias Ratio) használatát hedge fundok hozamainak elemzésére. A szerző célja kifejezetten az volt, hogy létrehozzon egy egyszerűen számítható mutatót, amelynek segítségével kiszűrheti azokat a hedge fundokat, amelyek feltételezhetően hozamsimítást, vagy egyéb manipulációt alkalmaznak elsősorban a ritkán árazódó, vagy nehezen értékelhető nettó eszközértékü portfólióelemeiken keresztül. Az így kiszürt hedge fundokat aztán részletesebb elemzéseknek érdemes alávetni, többek között külön elemezve a hedge fundban lévő elemek értékeltségét, likviditását. A Torzítási Ráta előnye, hogy alkalmazásával előszürhetőek azok az alapok, amelyek esetében érdemes és szükséges végrehajtani a portfóliójuk összetételére és értékeltségére vonatkozó elemzéseket, míg korábban ilyen eszköz híján lényegében az összes befektetési célpontot jelentő hedge fund értékeléséhez el kellett végezni ezeket a részletesebb számításokat az esetleges hozammanipuláció feltárásához.

A Torzítási Ráta a hedge fundok vagy befektetési alapok hozameloszlásából egyszerüen számítható formula, amely konkrét mércéje az alapok eszközeinek értékelésben fellelhető torzításnak: A hozamok eloszlásának alakját a 0-hozam körüli egy-egy szórásnyi kritikus sávjában méri, jelezve azon hedge fundokat, vagy befektetési alapokat, amelyek esetében felmerül a hozamsimítás lehetősége.

$$
\text { Torzítási Ráta }=\frac{\text { Megfigyelt gyakoriság }\left(r_{i}\right): r_{i} \in[0,+1.0 \sigma]}{1+\text { Megfigyelt gyakoriság }\left(r_{i}\right): r_{i} \in\left[\begin{array}{ll}
-1.0 \sigma, 0 & 0
\end{array}\right.},
$$

ahol $[0.0,+1.0 \sigma]$ a 0 -t is magában foglaló zárt intervallum a hozamok +1 szórásáig bezárólag. 
A $[-1.0 \sigma, 0.0)$ a félig zárt intervallum a hozamok -1 szórásától 0-ig, beleértve a -1 szórást is, de a 0 -t nem. A megfigyelt hozamokat $r_{i}$ jelöli.

A Torzítási Ráta az első és a második kvartilis görbe alatti terület arányát közelíti és az alábbi tulajdonságokkal bír:

1. $0 \leq \mathrm{TR} \leq \mathrm{n}$, ahol $\mathrm{n}$ a megfigyelt hozamok száma.

2. $\forall r_{i}$-re, ha $r_{i}<0$, akkor $\mathrm{TR}=0$

3. $\forall r_{i}$-re, ha $r_{i}>0, r_{i}>+1.0 \sigma$, akkor $\mathrm{TR}=0$

4. Ha $r_{i}$ normális eloszlást követ, 0 várható értékkel, akkor $\mathrm{TR} \rightarrow 1$, ha $\mathrm{n} \rightarrow \infty$.

A 0 átlaggal bíró, és normális eloszlású hedge fundoknak és befektetési alapoknak 1-nél kisebb a Torzítási Rátája, és elméleti alapon ezekre nincs nagy kereslet. A megfigyelések alátámasztják ezt, mivel a nagy piaci indexeknek 1-nél nagyobb a Torzítási Rátája. A készpénzbe és diszkontkötvény típusú eszközökbe fektető alapok és befektetési stratégiák relatíve konstans pozitív hozamokat generálnak, nagyon ritkán megjelenő veszteséges időszakokkal, aminek hatására a 0 körül jobbra ferde eloszlással rendelkeznek, következésképpen magas Torzítási Rátával is. Így Abdulali (2006) szerint a Torzítási Ráta használata kevésbé megbízható olyan befektetési alapok vagy hedge fundok esetében, amelyek magas készpénzjellegü befektetésekkel rendelkeznek.

Abdulali (2006) megfigyelése szerint a föbb részvényindexek 1 és 1,5 közötti Torzítási Ráta értékekkel bírnak. Az Abudali (2006) által vizsgált részvényalapú hedge fundok Torzítási Rátái 0,3 és 3 között szóródtak, 1,29-os várható érték és 0,5-es szórás mellett. Az eltérő befektetési stílust követő hedge fund-csoportok esetében széles szórást mutatnak a Torzítási Ráta értékek, valamint az egyes csoportok átlagai és mediánjai. Abdulali (2006) szerint az adott befektetési stílusba tartozó alapok csoportjára számított Torzítási Rátáinak mediánja fölött elhelyezkedő befektetési alapok, vagy hedge fundok esetében ajánlott további, a portfólió összetételére és árazási eljárására vonatkozó elemzéseket elvégezni.

Elméletben, ha hozamsimítás vagy az egyes illikvid eszközök kreatív értékelése áll a háttérben, akkor a közvetlenül 0 melletti pozitív és negatív hozamok gyakoriságában aránytalanságot fedezhetünk fel a pozitív hozamok irányában. A Diszkontinuitáselemzés során a befektetési alapok 0-körüli eloszlásában a diszkontinuitás jeleit 
keressük, amelyek a potenciális hozamsimítást tanúsíthatják. Az elemzés elvégzéséhez a hozamok eloszlását hisztogramon kell ábrázolnunk. Az osztályközök vastagságának megválasztása kritikus kérdése az elemzésnek, Bollen és Pool (2009)-t követve Silverman (1986) alapján az alábbi képletet javasolt használni:

$$
\mathrm{h}=0,9 \min \left[\sigma ; \frac{\mathrm{Q} 3-\mathrm{Q} 1}{1,34}\right] \mathrm{N}^{-0,2}
$$

ahol h az osztályok szélessége, $\sigma$ a hozamok szórása, $\mathrm{N}$ a megfigyelt hozamok száma, Q3 és Q1 pedig a megfelelő kvartilisek. Bollen és Pool (2009) alapján mind h meghatározásakor, mind a hisztogramok ábrázolásakor figyelmen kívül kell hagyni a kereken 0 hozamokat, mivel azok nem hozamsimítást jelentenek, hanem hiányzó adatokat, vagy a kereskedés hiányát.

A 0 körüli pozitív és negatív hozamok gyakoriságában megfigyelhető aránytalanságnak a mérése Bollen és Pool (2009), valamint Burgstahler és Dichev (1997) szerint úgy lehetséges, hogy megvizsgáljuk, hogy a 0 melletti pozitív és negatív hozamoknak a gyakorisága hogyan viszonyul a saját várható értékükhöz, valamint látszik-e törés az eloszlás lefutásában a szomszédos osztályokhoz viszonyítva. Mivel az eloszlásban megfigyelhető törés nem mindig egyértelmü, szükségünk van számszerü statisztikára is ennek megítéléséhez. Így az elemzés során azt lehet vizsgálni, hogy a 0 körüli hozamok gyakorisága hogyan viszonyul a megfigyelésekkel azonos várható értékü és szórású normális eloszláshoz. A statisztikai teszt, aminek az értékei felhasználhatóak a hisztogramokon is látható eloszlások lefutásának kiértékeléséhez Bollen és Pool (2009), valamint Burgstahler és Dichev (1997) apján az alábbi:

$$
Z=\frac{f-N p}{\sqrt{N p(1-p)}}
$$

ahol f a megfigyelt gyakoriság az adott osztályközben, $\mathrm{N}$ a megfigyelések száma, p pedig az adott osztályköznek a várható értéke, amelyet az elemzésünk során a megfelelő momentumokkal rendelkező normális eloszlás eloszlásfüggvényéből számoltunk.

Bollen és Pool (2009), Brown et al. (2010) és Burgstahler és Dichev (1997) egyaránt azt találták, hogy a 0 körüli negatív hozamok szignifikáns negatív eltérést mutattak a várható értékükhez képest, míg a pozitív hozamok pozitív irányban bizonyultak statisztikailag 
nagyobbnak a várható értéküknél, alátámasztva azt a hipotézist, hogy a 0 körüli pozitív hozamok gyakorisága feltehetően manipuláció eredményeképpen lett megnövelve a 0 körüli negatív hozamok ellenében. 


\section{SAJÁT SZÁMÍTÁSI EREDMÉNYEK}

A 2.1. fejezetben prezentáljuk az S\&P500 index részvényeinek negyedéves jelentéseit övező időszak vizsgált eseményeit, illetve a mintaválasztást meghatározó tényezőket, majd elvégezzük az 1.2. fejezetben leírt analitikus lépéseket.

Az alábbi kérdésekre keressük a választ:

1) A közzététel előtt, vagy után láthatók-e abnormális hozamok, amelyek az előbbi esetben a bennfentes információk kiszivárgására és lekereskedésére utalnak, míg utóbbi esetben a hírek hatására kialakuló trendet jelzik, ám mindkettő eset azt jelenti, hogy a piac nem teljesen hatékony.

2) A vállalati jelentésekben szereplő EPS-meglepetés iránya és nagysága hogyan befolyásolja a jelentést övező időszakban tapasztalt árfolyamreakciókat?

3) Vajon a technológiai szektorban tevékenykedő és bizonytalanabb értékeltséggel bíró tőzsdei vállalatok esetében a nagyobb bizonytalanságból fakadóan tapasztalható abnormális árfolyamreakciók felülmúlják-e az általános részvénypiachoz tartozó vállalatok esetében tapasztalt reakciókat?

Az eredményeink szerint a vállalatok profitabilitásában jelentkező meglepetés iránya és nagysága határozza meg azt, hogy hogyan módosulnak a részvényárfolyamok a bejelentés hatására. Ugyanakkor eltolódás figyelhető meg az egyes hírcsoportok esetén érzékelt kumulált abnormális hozamok szintjében és irányában a negatív ár-reakciók irányába, mivel szignifikáns pozitív hozam csak a nagyon jó hírek csoportjában jelentkezik. Az új információ hatása a bejelentést követő kereskedési napokon már nem figyelhető meg és nem alakul ki a meglepetés irányának megfelelő trend. Így az elemzés azt támasztja alá, hogy a kiválasztott mintában lévő részvények piaca közepesen hatékony. Általánosan szignifikánsan nagyobb árfolyamreakciók mutatkoznak az S\&P500 IT index hírcsoportjaiban az S\&P 500 indexhez viszonyítva.

A 2.2. fejezet saját számításokon mutatja be magyarországi abszolút hozamú befektetési alapok értékelését, és a hozammanipuláció vagy szuboptimális befektetési döntések nyomainak kimutatását új eredményként, mivel még nem ismert példa a 
hozammanipuláció nyomainak kimutatásra a szakirodalomban magyar befektetési alapok esetén.

Az alábbi új eredményeink születtek az elemzésünk során:

1) A Sharpe-ráta eredményeit összevetettük az MBTM eredményeivel és a rangkorreláció alapján kimutattuk bizonyos mértékü hozammanipulációnak a nyomait.

2) Új eredményként bemutattuk a különféle MBTM-verziók közötti érték és rangsorolás béli különbségeket mind az MBTM, mind a Kételkedési Hányados esetén.

3) Újításként javasoltuk a pontossága miatt az Ingersoll et al. (2007) -féle MBTM alkalmazását a Brown et al. (2010)-féle MBTM-el szemben mind a teljesítményértékeléshez, mind a Kételkedési Hányados számításához.

4) Elemeztük az MBTM-re épülő Kételkedési Hányados jelzőképességét a hozammanipuláció feltárásában, valamint viszonyulását az alternatív módszerekhez, a Torzítási Rátához, és a Diszkontinuitás-elemzéshez.

i. A Kételkedési Hányadosnak a szakirodalomban megfigyelt, az alternatív hozammanipulációt kimutató módszerekkel való szoros átfedésével (Brown et al. (2010) alapján 80\%-os egyezés) szemben az elemzett mintánkon felemás eredmények születtek, mivel az alternatív módszerek a 31 befektetési alapból 10-ből 4 esetben jeleztek jelentős anomáliát, azaz hozammanipulációt vagy szuboptimális befektetési döntéseket nagy valószínűséggel, míg a Kételkedési Hányados csak 4 befektetési alapot jelölt meg gyanúsnak, és abból 1-et erősítettek meg az alternatív módszerek is.

ii. Összességében tehát az eredményeink szerint a Torzítási Ráta jobb elöszürő eszköznek bizonyult a hozammanipuláció részletesebb elemzéséhez (pl. Diszkontinuitás-elemzéssel), mint a Kételkedési Hányados.

iii. Mindössze egy befektetési alap, a Concorde Citadella esetében tüntek megalapozottnak a gyanús jelzések a befektetési politikák és a befektetési alapkezelőkkel folytatott interjúk alapján, és ezt az alapot mind a Kételkedési Hányados, mind a Torzítási Ráta megjelölte. 


\subsection{NEGYEDÉVES JELENTÉSEK MEGLEPETÉS- HATÁSÁNAK ELEMZÉSE AZ S\&P 500 RÉSZVÉNYEI ESETÉN}

Ebben a fejezetben az S\&P500 index vállalatai által közzétett negyedéves jelentések részvényárfolyamra kifejtett hatását vizsgáljuk. A fejezetben tárgyaltak a kéziratcikkünkben, Rácz és Huszár (2018) és a publikált cikkünkben Rácz és Huszár (2019, pp. 251-262.) leírtakra épülnek. Ugyanakkor az ott leírtakhoz képest bővített idősorhosszúsággal (2015 első negyedévétől 2017 második negyedévéig tartó időszak helyett 2015 első negyedévétől - 2018 negyedik negyedévéig tartozó időszak, azaz 10 negyedév helyett 16 negyedév) és bővített számú elemzett részvénnyel (indexenként 3030 részvény helyett indexenként 45-45 darab), így az elemzett független negyedéves jelentések események száma 300-300 darabról 720-720-ra növekedett indexenként, valamint az ott alkalmazott hírkategóriára bontás (jó-semleges-rossz) helyett 5hírkategóriára bontással (nagyon jó, jó, semleges, rossz, nagyon rossz) végeztük el, hogy az EPS-meglepetésnek az ár-reakcióra való hatását ne csak a meglepetés iránya, de a nagysága szerint is vizsgálni lehessen. Fontos különbség még, hogy míg korábban 8 darab részvény mindkét indexben egyaránt szerepelt, addig most minden elemzett részvény csak az egyik vagy csak a másik index esetén szerepelhet így kiküszöbölve az átfedésből adódó metodológiai problémákat.

Egymáshoz szorosan kapcsolódó kérdéssekkel foglalkozunk:

1) A közzététel előtt, vagy után láthatók-e abnormális hozamok, amelyek az elöbbi esetben a bennfentes információk kiszivárgására és lekereskedésére utalnak, míg utóbbi esetben a hírek hatására kialakuló trendet jelzik, ám mindkettő eset azt jelenti, hogy a piac nem teljesen hatékony.

2) A vállalati jelentésekben szereplő EPS-meglepetés iránya és nagysága hogyan hat a jelentést övező időszakban tapasztalt árfolyamreakciókra?

3) Megfigyelhetö-e eltérés a különböző szektorok között az ár-reakció tekintetében? 
Az a hipotézisünk, hogy (1) a meglepetés iránya és nagysága határozza meg az árfolyamreakciók nagyságát és irányát, de a hatása nem érvényesül azonnal teljesen az árban, valamint (2) a technológiai szektorban erőteljesebb a meglepetés hatása az iparágban tevékenykedő vállalatok jóval bizonytalanabb alapokra épülő értékelése miatt.

Az elemzésekhez felhasznált adatok többségét a Bloomberg adatszolgáltató rendszerből töltöttük le 2019 júniusában. Kivételt képeznek az EPS adatok, amelyeknek forrása a Zacks Investment Research adatbázisa (Zacks Earnings Surprises, https://www.zacks.com/stocks/).

\section{A vizsgált hipotézisek}

Az elméleti áttekintésben bemutatott elméletek alapján úgy gondoljuk, hogy a részvénypiacok nem tökéletesen hatékonyak, mégis ezt tekintjük a kiindulási alapnak, amelyet kiegészítenek a viselkedési közgazdaságtan által leírt jelenségek. Mindezen megfontolások után az alábbi hipotéziseket fogalmazzuk meg:

1. A vállalatok profitabilitásában jelentkező meglepetés iránya és nagysága határozza meg azt, hogy hogyan módosulnak a részvényárfolyamok a bejelentés hatására, és az új információ hatása a bejelentést követő kereskedési napokon is megfigyelhető, a meglepetés irányának megfelelő trend alakul ki.

2. A meglepetés hatása erőteljesebben érvényesül a bizonytalan értékeltségü részvények, így a technológiai szektor esetében.

\section{A megfigyelt események ismertetése}

A prezentált eseményelemzéshez kiválasztott mintában az S\&P 500 és az S\&P 500 Information Technology (a továbbiakban S\&P500 IT) részvényindexek egyes elemei szerepelnek. Az első hipotézis teszteléséhez az indexek azon első 45-45 legnagyobb piaci kapitalizációval rendelkező részvényének árfolyammozgását figyeljük meg 2015 első és 2018 negyedik naptári negyedévei között közzétett negyedéves jelentéseik hatására, 
amelyekre hibátlanul rendelkeztünk mind az árfolyamadatokkal, mind az elemzői EPSelőrejelzésekkel, illetve a ténylegesen lejelentett EPS-eredményekkel. Azért használtuk az EPS-elörejelzéseket és EPS-eredményeket a meglepetés hatásának elemzéséhez, mivel egyrészt a részvények értékét a jövőbeli EPS-ek jelenértéke határozza meg, másrészt a vizsgált részvényeinkre az EPS-re rendelkezünk teljeskörü elörejelzett és tényadatokkal a vizsgált részvényeink esetében. Összesen tehát a 16 negyedév alatt 720720 jelentést vizsgálunk, tehát minden kiválasztott részvény 16 különálló eseményként került a mintába. Követve MacKinlay (1997) ajánlásait egy 4 hetes intervallumot felölelö 21 kereskedési napos eseményablakot választottunk az elemzéshez.

A mintára több szelekciós kritérium mentén esett a választás. A megfigyelések nagyvállalatokra irányulnak, amelyek részvényeivel likvid piacokon kereskednek. Egyrészt ezzel elkerülünk olyan módszertani problémákat, mint például a nem szinkronban történő kereskedés hatása. Másrészt így nem merülnek fel a kisebb kapitalizációjú, többnyire alacsonyabb likviditással rendelkező vállalatok esetén gyakrabban és intenzívebben megfigyelhető anomáliák, így megbízhatóbbak az elemzés konklúziói.

A második hipotézisünk azt feltételezi, hogy a technológiai részvények értékeltségük bizonytalansága miatt intenzívebben reagálnak az EPS meglepetésre. Ennek teszteléséhez az S\&P 500 és az S\&P500 IT Index 45-45 legnagyobb piaci kapitalizációjával rendelkező vállalatának negyedéves jelentései körül megfigyelhető árfolyammozgásait vetjük össze, amelyekre rendelkezünk hiánytalanul a szükséges adatokkal: árfolyam, EPS-előrejelzés, tényleges EPS-jelentés (lásd 9. táblázat). Így tehát összesen két, egyesével 720-720 egymást nem átfedő megfigyelésből álló mintán végeztük el a később ismertetett elemzéseket. A második minta esetében már nem mondható el a véletlenszerü ágazati megoszlás, ezt célszerü figyelembe venni az eredmények értelmezésénél is. 


\begin{tabular}{|c|c|c|}
\hline & S\&P500 & S\&P500 IT \\
\hline 1 & $3 \mathrm{M} \mathrm{Co}$ & Accenture \\
\hline 2 & Abbott Laboratories & Adobe \\
\hline 3 & Abbvie & Akamai Technologies Inc \\
\hline 4 & Altria Group Inc & Amphenol Corp \\
\hline 5 & Amazon & Analog Devices \\
\hline 6 & American Express Co & ANSYS Inc \\
\hline 7 & $\begin{array}{l}\text { American Tower } \\
\text { Corp }\end{array}$ & Apple \\
\hline 8 & AT\&T & Applied Materials \\
\hline 9 & Bank of America & Autodesk Inc \\
\hline 10 & Boeing & Automatic Data Processing \\
\hline 11 & Chevron & Broadcom \\
\hline 12 & Cisco & $\begin{array}{l}\text { Broadridge Financial Solutions } \\
\qquad \text { Inc }\end{array}$ \\
\hline 13 & Citigroup & Cadence Design Systems Inc \\
\hline 14 & Coca-Cola & Cisco \\
\hline 15 & Comcast & Cognizant Technology Solutions \\
\hline 16 & Danaher Corp & $\begin{array}{c}\text { Fidelity National Information } \\
\text { Services }\end{array}$ \\
\hline 17 & Eli Lilly \& Co & Fiserv Inc \\
\hline 18 & Exxon Mobil & FleetCor Technologies Inc \\
\hline 19 & Facebook & Global Payments Inc \\
\hline 20 & General Electric & $\mathrm{HP}$ \\
\hline 21 & Gilead Sciences Inc & IBM \\
\hline 22 & Google & Intel \\
\hline 23 & Home Depot & Intuit \\
\hline 24 & $\begin{array}{c}\text { Honeywell } \\
\text { International Inc }\end{array}$ & KLA-Tencor Corp \\
\hline 25 & Johnson \& Johnson & Lam Research Corp \\
\hline 26 & JPMorgan Chase & Mastercard \\
\hline 27 & $\begin{array}{l}\text { Lockheed Martin } \\
\text { Corp }\end{array}$ & Maxim Integrated Products Inc \\
\hline
\end{tabular}




\begin{tabular}{|c|c|c|}
\hline 28 & McDonald's Corp & Microchip Technology Inc \\
\hline 29 & Medtronic PLC & Micron Technology \\
\hline 30 & Merck & Microsoft \\
\hline 31 & Netflix Inc & Motorola Solutions Inc \\
\hline 32 & NextEra Energy Inc & NetApp Inc \\
\hline 33 & NIKE Inc & NVIDIA \\
\hline 34 & Pfizer & Qualcomm \\
\hline 35 & Philip Morris & Skyworks Solutions Inc \\
\hline 36 & Procter \& Gamble & Symantec Corp \\
\hline 37 & Starbucks Corp & Synopsys Inc \\
\hline 38 & $\begin{array}{l}\text { Thermo Fisher } \\
\text { Scientific Inc }\end{array}$ & $\begin{array}{l}\text { Take-Two Interactive Software } \\
\text { Inc }\end{array}$ \\
\hline 39 & Union Pacific Corp & TE Connectivity \\
\hline 40 & $\begin{array}{l}\text { United Technologies } \\
\text { Corp }\end{array}$ & Texas Instruments \\
\hline 41 & UnitedHealth Group & Total System Services Inc \\
\hline 42 & Verizon & VeriSign Inc \\
\hline 43 & Walmart Inc & Visa \\
\hline 44 & Walt Disney & Western Digital Corp \\
\hline 45 & Wells Fargo & Xilinx Inc \\
\hline
\end{tabular}

9. táblázat: Az S\&P500 és S\&P 500 IT legnagyobb piaci kapitalizációjú elemzett részvényei, amelyre rendelkeztünk a szükséges adatokkal

\section{A modellezés részletei}

A hipotézisek tesztelése elött számszerüsítenünk kell a vállalati eredményekben mutatkozó meglepetéshatást. Ezt követően a normális hozamok számítására alkalmazott regressziós modell paramétereinek becslését végezzük, végül pedig az abnormális hozamok kiszámítását, és adekvát módon történő aggregálását. 


\subsubsection{Az EPS adatok elemzése}

Egy eredmény bejelentésének meglepetéshatása leginkább az egy részvényre jutó eredmény (EPS) adott időszakra vonatkozó tényleges értéke és a vállalati jelentés közzétételét megelőző elemzői várakozások konszenzusának százalékos eltéréseként ragadható meg. Ez arra a feltételezésre épít, hogy az elemzői előrejelzések beépülnek a részvények árfolyamaiba. Önmagában a jelentés tehát kevéssé informatív az áralakulások megítélésében, ehhez elengedhetetlen a piaci várakozásokkal történő összehasonlítás. Az általunk használt becsült EPS érték a vállalati közzétételt időben közvetlenül megelőző elemzői becslések átlaga. Ezt a mutatót vetjük össze a jelentés napján megismert tényleges egy részvényre jutó eredménnyel. A tényadat tehát nem tartalmazza a vállalati eredmények később közzétett felülvizsgálatait, hiszen ezekről a piac az esemény idején még nem értesülhetett. Emellett a tényleges EPS módosított adat, amely meg van tisztítva különböző egyszeri és rendkívüli tételektől, mivel feltehetően jóval kevésbé érzékeny a piac a kiszürt egyedi, rendkívüli tételekre, mint a normál üzletmenetből létrejövő eredményre.

A mintaelemek adatainak összegyüjtését, illetve az EPS meglepetés kiszámítását követően MacKinlay (1997) eljárásához hasonlóan öt csoportba osztottuk a megfigyeléseket; nagyon jó, jó, rossz, nagyon rossz, illetve semleges hírt tartalmazó jelentésekre. Az elemzői konszenzustól $\pm 1 \%$-os sávon belülre eső EPS eltérés hírértékét semlegesnek tekintjük, a $+1 \%$ és $+4 \%$ közé eső EPS-meglepetéseket jónak, a $+4 \%$-nál nagyobb EPS-meglepetéseket pedig nagyon jónak, negatív meglepetések esetén ugyanez a logika csak - $1 \%$ és $-4 \%$-os határokkal.

Az S\&P 500-ból vett 720 elemü mintából 330 megfigyelés a nagyon jó, 206 a jó, 91 semleges, 30 a rossz, és 63 a nagyon rossz hír csoportjába került, míg az S\&P 500 IT esetén ez a megoszlás 411-193-26-15 elem. A 2. ábra két hisztogramján is ezek a gyakoriságok figyelhetők meg. Jóval gyakrabban fordul elő pozitív meglepetés, az eloszlása jobbra ferde. Ennek az lehet a magyarázata, hogy az elemzők becslései gyakran túl konzervatívak, ezáltal elkerülhetőek a negatív meglepetések. Az S\&P 500 ITindexből vett minta sokkal több esetben mutat az extrém EPS-meglepetés értékeket, mint az S\&P 500-ból vett minta. 
Az S\&P 500 IT indexből vett mintaelemek eloszlása következőképpen alakul: 1 esetben láthatunk 24\%-ot meghaladó negatív, és 58 -szor 24\%-ot meghaladó pozitív eltérést az előrejelzéshez képest, míg az S\&P 500-ból vett mintában ugyanez a két érték 27, illetve 40. Érdemes megjegyezni azt is, hogy a vizsgált időszak a konjunktúraciklus felfelé ívelő szakaszán történt, ami feltehetően gyakrabban okozott pozitív meglepetéseket.
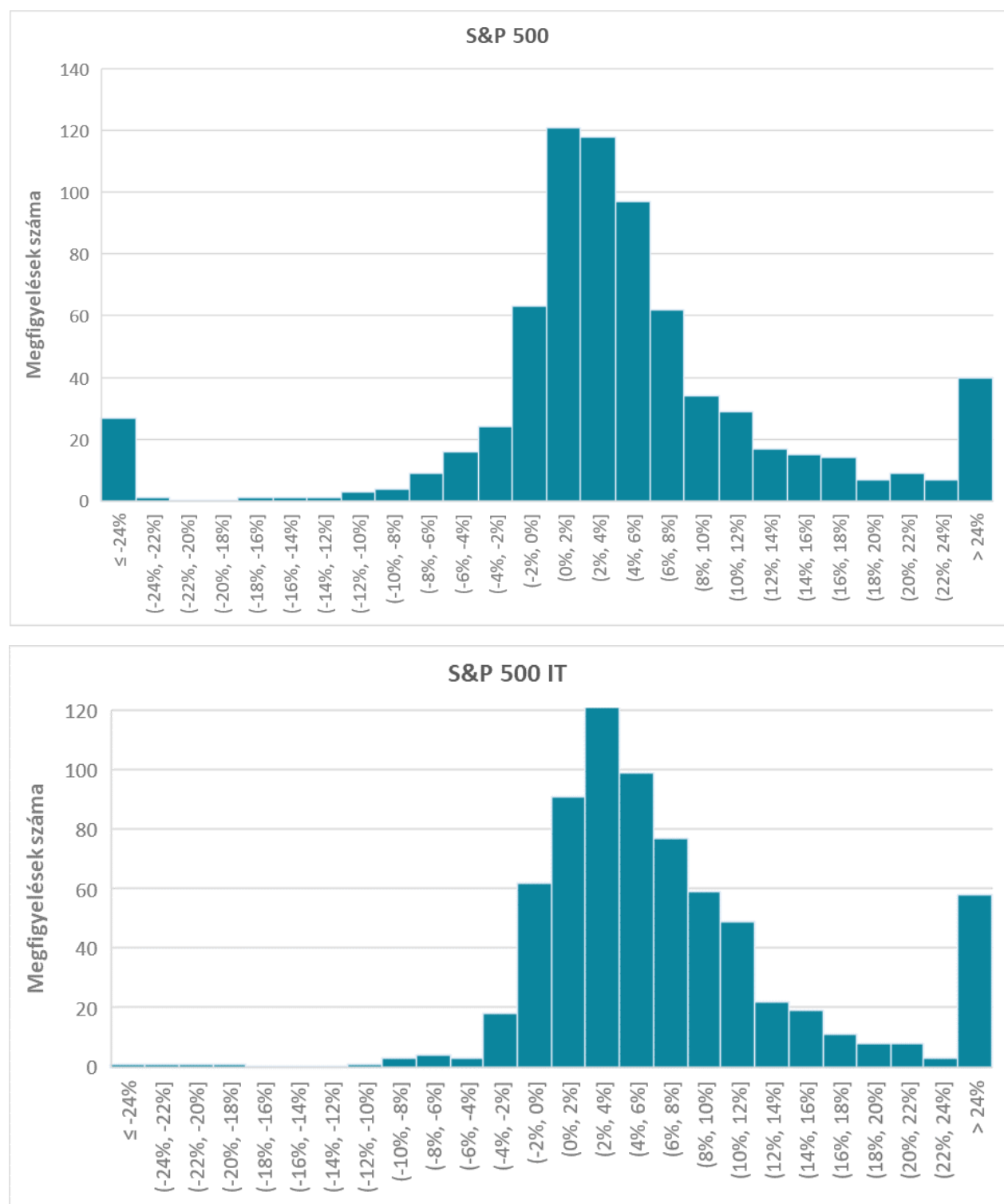

2. ábra: Az S\&P 500 és az S\&P 500 IT indexeiből vett megfigyelések esetén mutatkozó EPS meglepetés gyakoriságának eloszlása. 


\subsubsection{Paraméterbecslés és a hozamok modellezése}

A tényleges hozamokat összehasonlítjuk a piaci modell (2)-ben leírt regressziós egyenlete alapján számított értékeivel. A becslési időszak minden esetben az adott megfigyelés eseményablakát megelözö 500 kereskedési napos intervallum. Erre azért van szükség, mert az idő során változhatnak a modell paraméterei egyedi részvények esetén is. Így tehát mind a 720-720 megfigyelésre külön-külön történik a becslés, nem pedig csak értékpapíronként, ami növeli a modell magyarázó erejét, valamint pontosabbá teszi az abnormális hozamok kalkulációját. A piaci portfóliót a modellben az S\&P 500 részvényindex testesítette meg mind az elemzett két részvényindexhez tartozó részvények esetén.

A Bloomberg adatbázisából letöltött árfolyamadatokból minden releváns megfigyelési időszakra kiszámoltuk a napi logaritmikus hozamokat az egyedi részvényekre és az S\&P 500, illetve S\&P500 IT indexekre. Ez alapján megbecsültük a regressziós modell paramétereit. A két mintára 720-720 lineáris regressziót illesztettünk, hiszen minden egyes részvény $\hat{\alpha}$ és $\hat{\beta}$ paraméterei időben változnak.

A modellek illeszkedését leíró $R^{2}$ mutatók igen nagy terjedelemben mozognak és gyakran viszonylag alacsony az értékük. Ez persze nem annyira meglepő, hiszen a béta csupán a részvény piaci kockázatát fejezi ki, a különböző idioszinkratikus sokkok viszont jelentősen eltéríthetik a valós hozamokat a modell által előre jelzett értékektől. Gospodinov és Robotti (2013) is megjegyzi, hogy a hozamok előrejelzésére használt modellek ugyan jellemzően alacsony $R^{2}$ mutatókat eredményeznek, ezek gazdasági szempontból relevánsnak tekinthetők. 


\subsubsection{Az abnormális hozamok számítása és aggregálása}

Ebben az alfejezetben az abnormális hozamok számításának és aggregálásának lépéseit közöljük. Elérkeztünk a kutatás szempontjából legérdekesebb részhez, az abnormális hozamok számításához, amely a (4) egyenlet alapján történik. A hipotézisek teszteléséhez szükséges a kiszámított adatpontokat a 1.2.3. fejezetben leírtak mentén kell aggregálni. Egyrészt világos, hogy a mintán belül alkotott öt csoportot (nagyon jó, jó, semleges, rossz és nagyon rossz hír) külön-külön célszerü vizsgálni, ezért az eseményablak minden periódusára kiszámítjuk a csoportok átlagos abnormális hozamait (5) szerint. A kérdés, hogy az időben történő aggregálást milyen $\tau_{1}$ és $\tau_{2}$ periódusok között tegyük meg a megfelelő hipotézisek teszteléséhez.

\begin{tabular}{|c|c|c|c|c|c|c|c|c|c|c|}
\hline \multirow{3}{*}{$\tau$} & \multicolumn{10}{|c|}{ S\&P 500} \\
\hline & \multicolumn{2}{|c|}{ Nagyon Jó Hír } & \multicolumn{2}{|c|}{ Jó Hír } & \multicolumn{2}{|c|}{ Semleges Hír } & \multicolumn{2}{|c|}{ Rossz Hír } & \multicolumn{2}{|c|}{ Nagyon Rossz } \\
\hline & AR & CAR & AR & CAR & $A R$ & CAR & AR & CAR & AR & CAR \\
\hline-10 & $0,00 \%$ & $0,00 \%$ & $0,17 \%$ & $0,17 \%$ & $0,39 \%$ & $0,39 \%$ & $-0,18 \%$ & $-0,18 \%$ & $-0,97 \%$ & $-0,97 \%$ \\
\hline-9 & $0,11 \%$ & $0,12 \%$ & $0,01 \%$ & $0,18 \%$ & $-0,14 \%$ & $0,25 \%$ & $0,08 \%$ & $-0,10 \%$ & $-0,60 \%$ & $-1,57 \%$ \\
\hline-8 & $0,06 \%$ & $0,18 \%$ & $0,14 \%$ & $0,32 \%$ & $0,06 \%$ & $0,31 \%$ & $-0,78 \%$ & $-0,88 \%$ & $-0,30 \%$ & $-1,87 \%$ \\
\hline-7 & $-0,13 \%$ & $0,05 \%$ & $-0,17 \%$ & $0,15 \%$ & $0,16 \%$ & $0,47 \%$ & $0,05 \%$ & $-0,83 \%$ & $-0,67 \%$ & $-2,55 \%$ \\
\hline-6 & $0,15 \%$ & $0,20 \%$ & $0,11 \%$ & $0,25 \%$ & $-0,27 \%$ & $0,20 \%$ & $0,27 \%$ & $-0,56 \%$ & $-0,01 \%$ & $-2,56 \%$ \\
\hline-5 & $-0,03 \%$ & $0,17 \%$ & $-0,30 \%$ & $-0,04 \%$ & $-0,16 \%$ & $0,04 \%$ & $-0,73 \%$ & $-1,29 \%$ & $-0,01 \%$ & $-2,57 \%$ \\
\hline-4 & $-0,06 \%$ & $0,11 \%$ & $-0,02 \%$ & $-0,06 \%$ & $-0,80 \%$ & $-0,75 \%$ & $0,29 \%$ & $-0,99 \%$ & $0,81 \%$ & \\
\hline-3 & $0,03 \%$ & $0,14 \%$ & $0,01 \%$ & $-0,04 \%$ & $-0,03 \%$ & $-0,78 \%$ & $-0,19 \%$ & $-1,18 \%$ & $-1,13 \%$ & $-2,89 \%$ \\
\hline-2 & $-0,03 \%$ & $0,11 \%$ & $0,06 \%$ & $0,02 \%$ & $-0,25 \%$ & $-1,03 \%$ & $0,37 \%$ & $-0,81 \%$ & $0,53 \%$ & $-2,36 \%$ \\
\hline-1 & $0,05 \%$ & $0,16 \%$ & $-0,17 \%$ & $-0,15 \%$ & $-0,22 \%$ & $-1,25 \%$ & $0,37 \%$ & $-0,44 \%$ & $0,10 \%$ & $-2,26 \%$ \\
\hline 0 & $0,38 \%$ & $0,54 \%$ & $0,04 \%$ & $-0,10 \%$ & $0,19 \%$ & $-1,05 \%$ & $0,45 \%$ & $0,02 \%$ & $-1,65 \%$ & $-3,91 \%$ \\
\hline 1 & $1,06 \%$ & $1,60 \%$ & $-0,05 \%$ & $-0,16 \%$ & $-0,64 \%$ & $-1,69 \%$ & $-3,20 \%$ & $-3,19 \%$ & $-4,39 \%$ & $-8,29 \%$ \\
\hline 2 & $0,07 \%$ & $1,67 \%$ & $-0,08 \%$ & $-0,24 \%$ & $-0,24 \%$ & $-1,94 \%$ & $-0,18 \%$ & $-3,37 \%$ & $0,52 \%$ & $-7,77 \%$ \\
\hline 3 & $-0,16 \%$ & $1,51 \%$ & $0,18 \%$ & $-0,05 \%$ & $0,08 \%$ & $-1,86 \%$ & $0,05 \%$ & $-3,32 \%$ & $0,26 \%$ & $-7,51 \%$ \\
\hline 4 & $0,06 \%$ & $1,57 \%$ & $-0,12 \%$ & $-0,17 \%$ & $0,06 \%$ & $-1,79 \%$ & $0,13 \%$ & $-3,19 \%$ & $0,54 \%$ & $-6,98 \%$ \\
\hline 5 & $0,11 \%$ & $1,68 \%$ & $-0,12 \%$ & $-0,29 \%$ & $-0,06 \%$ & $-1,85 \%$ & $-0,36 \%$ & $-3,55 \%$ & $0,50 \%$ & $-6,48 \%$ \\
\hline 6 & $-0,04 \%$ & $1,64 \%$ & $0,16 \%$ & $-0,14 \%$ & $-0,07 \%$ & $-1,92 \%$ & $0,04 \%$ & $-3,52 \%$ & $-0,38 \%$ & $-6,86 \%$ \\
\hline 7 & $0,10 \%$ & $1,75 \%$ & $0,06 \%$ & $-0,08 \%$ & $-0,14 \%$ & $-2,06 \%$ & $0,26 \%$ & $-3,26 \%$ & $0,14 \%$ & $-6,72 \%$ \\
\hline 8 & $0,05 \%$ & $1,79 \%$ & $0,07 \%$ & $-0,01 \%$ & $0,01 \%$ & $-2,05 \%$ & $-0,42 \%$ & $-3,68 \%$ & $0,02 \%$ & $-6,71 \%$ \\
\hline 9 & $-0,07 \%$ & $1,73 \%$ & $-0,08 \%$ & $-0,09 \%$ & $-0,24 \%$ & $-2,29 \%$ & $0,35 \%$ & $-3,33 \%$ & $-0,41 \%$ & $-7,11 \%$ \\
\hline 10 & $-0,09 \%$ & $1,63 \%$ & $-0,01 \%$ & $-0,11 \%$ & $0,43 \%$ & $-1,86 \%$ & $0,02 \%$ & $-3,30 \%$ & $0,48 \%$ & $-6,63 \%$ \\
\hline
\end{tabular}




\begin{tabular}{|c|c|c|c|c|c|c|c|c|c|c|}
\hline \multirow{3}{*}{$T$} & \multicolumn{10}{|c|}{ S\&P 500 IT } \\
\hline & \multicolumn{2}{|c|}{ Nagyon Jó Hír } & \multicolumn{2}{|c|}{ Jó Hír } & \multicolumn{2}{|c|}{ Semleges Hír } & \multicolumn{2}{|c|}{ Rossz Hír } & \multicolumn{2}{|c|}{ Nagyon Rossz } \\
\hline & $\mathrm{AR}$ & CAR & $A R$ & CAR & $A R$ & CAR & $A R$ & CAR & $A R$ & CAR \\
\hline-10 & $0,11 \%$ & $0,11 \%$ & $-0,02 \%$ & $-0,02 \%$ & $0,03 \%$ & $0,03 \%$ & $0,04 \%$ & $0,04 \%$ & $0,03 \%$ & $0,03 \%$ \\
\hline-9 & $0,04 \%$ & $0,15 \%$ & $0,02 \%$ & $0,00 \%$ & $-0,08 \%$ & $-0,05 \%$ & $-0,10 \%$ & $-0,07 \%$ & $-0,17 \%$ & $-0,14 \%$ \\
\hline-8 & $0,08 \%$ & $0,23 \%$ & $0,03 \%$ & $0,02 \%$ & $-0,04 \%$ & $-0,09 \%$ & $-0,15 \%$ & $-0,21 \%$ & $-0,07 \%$ & $-0,21 \%$ \\
\hline-7 & $0,14 \%$ & $0,37 \%$ & $0,03 \%$ & $0,05 \%$ & $0,07 \%$ & $-0,02 \%$ & $-0,08 \%$ & $-0,29 \%$ & $-0,01 \%$ & $-0,22 \%$ \\
\hline-6 & $0,03 \%$ & $0,41 \%$ & $-0,15 \%$ & $-0,10 \%$ & $-0,11 \%$ & $-0,13 \%$ & $0,08 \%$ & $-0,21 \%$ & $0,09 \%$ & $-0,12 \%$ \\
\hline-5 & $-0,02 \%$ & $0,39 \%$ & $-0,13 \%$ & $-0,23 \%$ & $-0,03 \%$ & $-0,16 \%$ & $0,31 \%$ & $0,10 \%$ & $0,01 \%$ & $-0,11 \%$ \\
\hline-4 & $-0,06 \%$ & $0,33 \%$ & $-0,06 \%$ & $-0,29 \%$ & $0,09 \%$ & $-0,07 \%$ & $-0,03 \%$ & $0,07 \%$ & $0,00 \%$ & $-0,11 \%$ \\
\hline-3 & $0,00 \%$ & $0,32 \%$ & $0,11 \%$ & $-0,17 \%$ & $0,04 \%$ & $-0,03 \%$ & $-0,01 \%$ & $0,06 \%$ & $0,21 \%$ & $0,10 \%$ \\
\hline-2 & $0,00 \%$ & $0,32 \%$ & $-0,06 \%$ & $-0,24 \%$ & $0,10 \%$ & $0,07 \%$ & $-0,10 \%$ & $-0,04 \%$ & $0,01 \%$ & $0,11 \%$ \\
\hline-1 & $-0,15 \%$ & $0,17 \%$ & $-0,05 \%$ & $-0,28 \%$ & $-0,10 \%$ & $-0,04 \%$ & $0,13 \%$ & $0,08 \%$ & $0,15 \%$ & $0,26 \%$ \\
\hline 0 & $0,89 \%$ & $1,06 \%$ & $0,07 \%$ & $-0,21 \%$ & $-0,77 \%$ & $-0,80 \%$ & $-1,80 \%$ & $-1,72 \%$ & $-0,40 \%$ & $-0,14 \%$ \\
\hline 1 & $0,29 \%$ & $1,35 \%$ & $0,16 \%$ & $-0,05 \%$ & $-0,15 \%$ & $-0,95 \%$ & $-1,08 \%$ & $-2,80 \%$ & $-1,11 \%$ & $-1,25 \%$ \\
\hline 2 & $-0,17 \%$ & $1,18 \%$ & $-0,09 \%$ & $-0,15 \%$ & $0,08 \%$ & $-0,87 \%$ & $-0,22 \%$ & $-3,03 \%$ & $-0,24 \%$ & $-1,49 \%$ \\
\hline 3 & $-0,16 \%$ & $1,02 \%$ & $-0,05 \%$ & $-0,20 \%$ & $0,02 \%$ & $-0,85 \%$ & $0,20 \%$ & $-2,83 \%$ & $-0,14 \%$ & $-1,63 \%$ \\
\hline 4 & $-0,07 \%$ & $0,95 \%$ & $-0,03 \%$ & $-0,23 \%$ & $-0,04 \%$ & $-0,89 \%$ & $-0,17 \%$ & $-3,00 \%$ & $0,02 \%$ & $-1,61 \%$ \\
\hline 5 & $-0,16 \%$ & $0,79 \%$ & $0,08 \%$ & $-0,15 \%$ & $-0,11 \%$ & $-1,00 \%$ & $0,02 \%$ & $-2,98 \%$ & $-0,11 \%$ & $-1,71 \%$ \\
\hline 6 & $-0,13 \%$ & $0,66 \%$ & $-0,04 \%$ & $-0,19 \%$ & $-0,17 \%$ & $-1,18 \%$ & $0,11 \%$ & $-2,87 \%$ & $-0,04 \%$ & $-1,75 \%$ \\
\hline 7 & $-0,02 \%$ & $0,64 \%$ & $0,03 \%$ & $-0,16 \%$ & $0,08 \%$ & $-1,09 \%$ & $0,22 \%$ & $-2,65 \%$ & $-0,08 \%$ & $-1,83 \%$ \\
\hline 8 & $0,02 \%$ & $0,66 \%$ & $-0,02 \%$ & $-0,18 \%$ & $0,12 \%$ & $-0,97 \%$ & $-0,52 \%$ & $-3,18 \%$ & $-0,12 \%$ & $-1,95 \%$ \\
\hline 9 & $0,05 \%$ & $0,71 \%$ & $0,07 \%$ & $-0,11 \%$ & $-0,09 \%$ & $-1,06 \%$ & $0,16 \%$ & $-3,02 \%$ & $-0,03 \%$ & $-1,98 \%$ \\
\hline 10 & $0,06 \%$ & $0,77 \%$ & $-0,06 \%$ & $-0,17 \%$ & $-0,02 \%$ & $-1,08 \%$ & $-0,25 \%$ & $-3,27 \%$ & $0,25 \%$ & $-1,73 \%$ \\
\hline
\end{tabular}

10. táblázat: Az öt meglepetéskategória átlagos és kumulatív átlagos abnormális hozamai az esemény körüli időszakban a két részvényindexből vett minta esetén.

Kétféleképpen tesztelhető, hogy a meglepetés irányával megegyezik-e az árfolyamok mozgása. Az egyik megoldás, hogy a teljes eseményablakra számított kumulatív abnormális hozamot tekintjük $\overline{C A R}(-10,10)$. Feltételezve azonban, hogy az információ azonnal beépül az árfolyamokba logikus választás erre $\overline{C A R}(0,1)$, amely a bejelentés napját és a közvetlenül utána következő napot foglalja magában, illetve $\overline{C A R}(0,10)$ is, ahol csak az esemény után következő kereskedési napon, illetve napokban megfigyelt átlagos abnormális hozamokat kumuláljuk. Mivel sajnos nem rendelkezünk információval arról, hogy az elemzett jelentések a napon belül pontosan mikor következtek be, ezért, hogy a kereskedési idő után közzétett jelentések hatását is mérni lehessen $\overline{C A R}(0,1)$ intervallumot kell használnunk a jelentések azonnali hatásának vizsgálatához. Azt pedig, hogy megfigyelhető-e az árfolyamban a jelentés után momentum, értelemszerüen egy elcsúsztatott ablakkal célszerű vizsgálni, mint például $\overline{C A R}(2,10)$. Míg az esetleges bennfentes információk kiszivárgását a $\overline{C A R}(-10,-1)$ jelezheti. 
A 10. táblázat, illetve a 3. ábra jól megfigyelhetően mutatja a negyedéves jelentések részvényárfolyamra gyakorolt hatását. Egészen a bejelentés előtti kereskedési napig minimális abnormális hozamok figyelhetők meg az S\&P 500 index mindegyik csoportjában. Ugyanez a tendencia mondható el az S\&P500 IT nagyon jó és jó csoportjainak bejelentés előtti abnormális hozamairól. Ugyanakkor a semleges, rossz és nagyon rossz hírek csoportjában az adatok alapján már a bejelentés nyilvánosságra hozatala előtti napokban jelentősebb negatív kumulált abnormális hozamokat látunk. A közzététel idején a két szélső csoport kumulatív abnormális hozama mind az S\&P500, mind az S\&P500 IT index esetén a meglepetés irányának megfelelően kilő.

A meglepetés nagysága és a tapasztalt abnormális hozamok nagysága között alapvetően jól kivehető a pozitív irányú kapcsolat, ugyanakkor a fentiekben taglalt aszimmetria a negatív hírek irányában általános. Míg a nagyon jó hírek csoportjában a bejelentéseket követően $1 \%$, illetve $2 \%$ körüli szinteken stabilizálódó kumulált abnormális hozamot látunk a két index esetében, és a jó hírek esetén 0-hoz igen közel eső negatív kumulált abnormális hozamot, addig a rossz hírek csoportjában -2\% és -3\% körül stabilizálódókat, a nagyon rossz hírek esetében pedig $-3 \%$ és $-7 \%$ körül. A semleges hírek csoportjai esetében pedig a bejelentést követően a kumulált abnormális hozam a $-1 \%$, illetve és $2 \%$ körül stabilizálódik. Az a tény, hogy a semleges és enyhén pozitív EPSmeglepetéseket összességében negatív abnormális hozamokkal reagálja le a piac azt a meglátást támasztja alá, hogy egy gazdasági felíveléssel leírható időszakban nagyon magasan vannak a piaci szereplők elvárásai, és még egy egyébként pozitív vagy semleges negyedéves tényadatot is csalódásnak élnek meg, ha az elmarad a várakozásaiktól.

Az S\&P500 index rossz csoportjának reakciója összevethető az S\&P500 IT abnormális hozamaival. Viszont míg utóbbi nagyon rossz hírcsoportja igen nagy negatív kumulált abnormális hozamokat mutat, addig előbbi esetén a -2\%-os kumulált abnormális hozam némileg meglepő eredmény. Ez ugyanis azt jelenti, hogy a piac jobban büntetett a -1 és -4\%-os sávba eső EPS-meglepetésekért általánosságban az S\&P500 index esetén, mint a -4\%-ot is meghaladó mértékü EPS-meglepetések esetén. 
Jól látható, hogy még a jelentést követő kereskedési napon is erős a meglepetés hatása, amit a késői tőzsdei órákban vagy a zárás utáni közzétételek okoznak. A bejelentést követő második kereskedési naptól kezdve viszont már csak minimális változás figyelhető meg a kumulatív átlagos abnormális hozamban mindegyik hírcsoportban és mindkét index esetében. Az új információ beépül a részvény árfolyamába és a továbbiakban ismét nulla körül alakulnak az abnormális hozamok.

Megfigyelve a kumulatív abnormális hozamok elmozdulásának nagyságát, a 0-8,3 százalékpontos sávban szóródó értékeket láthatunk. Mielőtt megtévesztenének minket ezek a részvénypiacokon nem túl kiugró értékek, vegyük figyelembe, hogy ezek csak abnormális hozamok, amelyekből az egyéb piaci hatások nagy részét már kiszürtük a várható hozamok modellezésével. Sőt, átlagos értékeket szemlélünk részvények egész csoportjára, azonban egyedi esetekben nem ritka a mintában akár kétszámjegyü napi abnormális hozam sem.

A $\overline{C A R}(-10,10)$ értékekhez hasonlóan elemezhetők a kumulatív átlagos abnormális hozamok bármilyen $\left(\tau_{1}, \tau_{2}\right)$ intervallumon. A hipotézisvizsgálat során a 10 . és 11 . táblázat mutatja ezeket az eredményeket. Figyelembe véve azonban, hogy mindkét minta csoportjaiban érdemben magasabb a pozitív tartományba eső EPS meglepetések aránya (lásd 2. ábra), ez valószínüleg a véletlen szerepe mellett annak is köszönhető, hogy a 2008-as gazdasági válságot követő felívelő gazdasági ciklusból származik a minta. Emiatt megfontolandó, hogy inkább a hosszabb intervallumok teszteredményeit tekintsük irányadónak. 

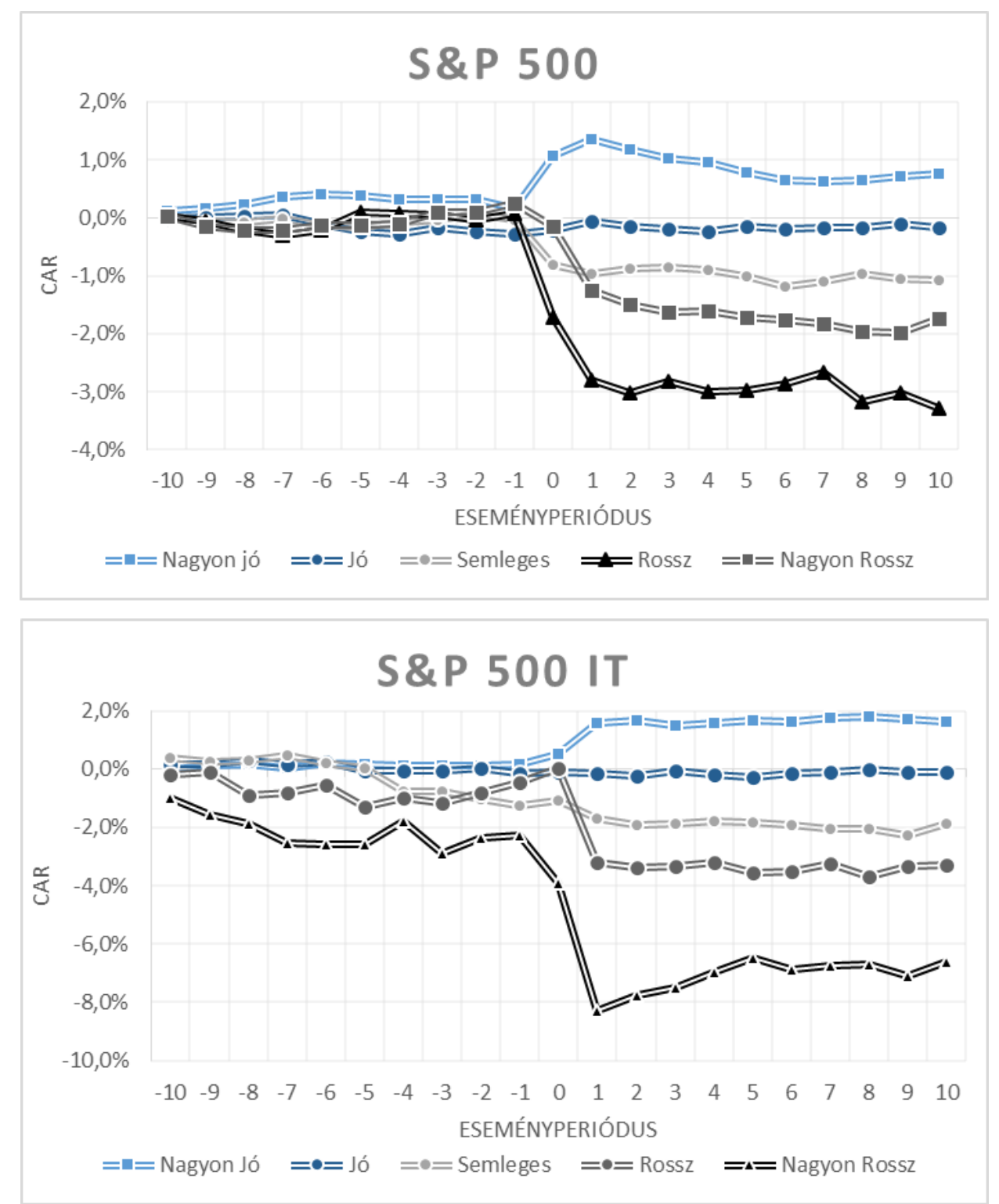

3. ábra: Az öt csoport kumulatív átlagos abnormális hozamai az esemény körüli időszakban a két részvényindexből vett minta esetén nagyon jó, jó, semleges, rossz és nagyon rossz hírek csoportjának esetén. 


\section{Hipotézisvizsgálat és az eredmények értelmezése}

A 3. ábra elég látványosan prezentálja a megfigyelési csoportok átlagos abnormális hozamainak alakulását ahhoz, hogy a kutatás elején megfogalmazott sejtésekről határozottabb képet alkothassunk. A hipotéziseinket részben megerősíti, részben gyengíti ez a kép. Ahhoz viszont, hogy megállapítható legyen, valóban szignifikáns jelenségeket figyelhetünk-e meg, szükséges a hipotézisek statisztikai vizsgálata. Ezek tekinthetők át az alábbi két alfejezetben.

\subsection{4. Árfolyam-reakciók a negyedéves jelentések hatására}

Ez az alfejezet tartalmazza az árfolyamreakciók elemzését az abnormális hozamok meglétének hipotézisvizsgálatának segítségével. Ahhoz, hogy megtudjuk, ezek az átlagok valóban szignifikánsan különböznek-e a nullától, egymintás Student-féle $t$ próbákat végeztünk. A tesztelt nullhipotézisek és alternatív hipotézisek a disszertáció első hipotézisének vizsgálatakor minden esetben a következő alakban írhatók fel:

$$
H_{0}: \theta=0 \quad H_{1}: \theta \neq 0,
$$

ahol $\theta$ a (13) egyenlet alapján a $\tau_{1}$ és $\tau_{2}$ közti intervallumon mért kumulatív átlagos abnormális hozam, valamint az ehhez tartozó szórás hányadosaként meghatározott tesztstatisztika. A nullhipotézis tehát azt feltételezi, hogy az így számított érték standard normális eloszlásból származik. A közgazdasági intuíció alapján arra számíthatunk, hogy a semleges hírt tartalmazó jelentések csoportjában elfogadjuk, a pozitív és negatív meglepetések esetében pedig elutasítjuk a nullhipotézist

A 10. és 11. táblázat tartalmazza az S\&P 500, illetve az S\&P 500 IT indexből vett minta $\overline{C A R}$ értékeit és szórásait ( $s$ jelöli ezt a szórást, amely megegyezik a (11) egyenletben szereplö variancia négyzetgyökével), valamint a nagyon jó, jó, semleges, rossz és nagyon rossz csoportokra különböző intervallumokra számított tesztstatisztikáit. A 1.2. fejezetben már említettük, hogy a kumulatív átlagos abnormális hozamok varianciájának becslése a becslési időszakra (2) alapján számított $\hat{\sigma}_{\varepsilon_{i}}^{2}$ hibatag-varianciák felhasználásával történik a (7) egyenlet szerint. Mivel a (7) egyenletben az elemszám 
négyzete szerepel a nevezőben, világos, hogy kisebb elemszámú csoportok esetén általában nagyobb varianciát kapunk, ami növeli a nullhipotézis elfogadásának valószínüségét.

A módszertan leírása során említettük, hogy a variancia becslésében torzítást okoz az események dátumainak klasztereződése. Binder (1998), illetve Rao és Sreejith (2014) kifejtik, hogy ez viszonylag kis problémát okoz, ha nincs totális klasztereződés és nagyjából véletlenszerü a megfigyelések időbeli eloszlása. Az esemény jellegéből ítélve a negyedéves jelentések általában egy bő egyhónapos időszakra esnek. Néhány érték nem illik bele ebbe a mintázatba, mivel egyes vállalatok üzleti évei nem egyeznek meg a naptári évekkel. Az azonban semmiképp sem mondható, hogy totális klasztereződés lenne, mivel az elemzés 4 évet ölel fel és a jelentések dátumai még negyedéven belül is viszonylag széles intervallumon szóródnak.

Mivel kétoldali próbákkal vizsgáljuk a hipotéziseket, ezért $t_{0,975}$ jelöli a t-eloszlás $95 \%$ os, $t_{0,995}$ pedig az 99\%-os szignifikancia szint mellett számított kritikus értékeit. Nyilvánvalóan ezek a között a csoportok között is eltéréseket mutatnak, mivel minden esetben különböző $(N-1)$ a tesztek szabadságfoka. Mivel az eloszlás szimmetrikus, a baloldali kritikus értékek a jobboldaliak mínusz egyszeresének felelnek meg, ezeket külön nem tüntettük fel a táblázatban. A teszthez 95\%-os szignifikanciaszintet alkalmazva tehát például a 11. táblázat első sorában az elfogadási tartomány a -1,97 és 1,97 közötti zárt intervallum.

Az S\&P 500 értékeit áttekintve az látható, hogy a teljes eseményablak $(-10,10)$ intervallumán szignifikáns kumulált abnormális hozamokat találunk a nagyon jó, a rossz és a nagyon rossz hírek esetén, viszont a jó hírek esetében nincs szignifikáns kumulált abnormális hozam. A semleges hírek esetében viszont szintén szignifikáns a kumulált abnormális hozam -1,08\%-os értékkel. A kumulált abnormális hozamok iránya és szintje, valamint a tapasztalt meglepetés iránya és nagysága között pozitív kapcsolat figyelhető meg. A piac ugyanakkor eltolódik a negatív ár-reakciók irányába, mert míg a nagyon jó hírek csoportjában a kumulált abnormális hozam nagysága $0,77 \%$, addig a jó hírek esetében -0,17\% (bár az értéke nem szignifikánsan különbözik 0-tól), a semleges hírek esetében $-1,08 \%$, a rossz és a nagyon rossz hírek esetében pedig -3,27\% és -1,73\%. 
Feltételezhetően a tapasztalt szignifikáns ár-reakciók mögött az húzódik meg, hogy a 2008-as nagy világgazdasági sokkot követő gazdasági felívelést jellemző emelkedő részvényárakkal leírható trendben a piaci szereplők vállalatok jelentéseivel szembeni elvárásai magasan vannak, és míg a várakozásokat meghaladó hírekre visszafogott árnövekedéssel reagálnak (konzervativizmus Barberis et al. (1998)), a várakozásoktól jelentősen elmaradó vállalatok esetében komolyabb negatív ár-reakció alakul ki (túlzott magabiztosság, attribúciós elmélet Daniel, et al. (1998)). A semleges hírek csoportjának negatív irányú abnormális hozama magyarázható lehet azzal, hogy a piaci szereplők ilyen felfokozott várakozások mellett még a +/-1\%-os sávba eső EPS-meglepetéseket is negatív hírként értékelik.

A rossz és a nagyon rossz hírek csoportjai esetén tapasztalt eltérés a kumulált abnormális hozam nagyságában némileg meglepő sorrendcserét jelent a várakozásainkhoz viszonyítva, hiszen a kisebb meglepetésre, nagyobb abnormális hozamokat találunk a két hírcsoport viszonylatában. Ennek magyarázata talán az is lehet, hogy a vállalati EPS milyen változást mutat az előző negyedéves, vagy egy évvel korábbi EPS értékhez képest, vagy az is elképzelhető, hogy számít a piaci hangulat is a bejelentés napján. Ezeknek a hatásoknak a számszerüsítésére további kutatások során érdemes lenne kitérni. 


\begin{tabular}{|c|c|c|c|c|c|c|c|c|}
\hline S\&P 500 & $\tau_{1}, \tau_{2}$ & $C A R$ & s & $\theta$ & Szabadságfok & $t_{0,975}$ & $t_{0,995}$ & $p$ \\
\hline \multirow{5}{*}{ Nagyon jó hír } & $-10,10$ & $0,77 \%$ & $0,30 \%$ & 2,54 & 329 & 1,97 & 2,59 & 0,0114 \\
\hline & $-10-1$ & $0,17 \%$ & $0,21 \%$ & 0,84 & 329 & 1,97 & 2,59 & 0,4037 \\
\hline & 0,10 & $0,60 \%$ & $0,22 \%$ & 2,72 & 329 & 1,97 & 2,59 & 0,0069 \\
\hline & 0,1 & $1,17 \%$ & $0,09 \%$ & 12,55 & 329 & 1,97 & 2,59 & 0,0000 \\
\hline & 2,10 & $-0,58 \%$ & $0,20 \%$ & $-2,91$ & 329 & 1,97 & 2,59 & 0,0038 \\
\hline \multirow{5}{*}{ Jó hír } & $-10,10$ & $-0,17 \%$ & $0,33 \%$ & $-0,53$ & 205 & 1,97 & 2,60 & 0,5952 \\
\hline & $-10-1$ & $-0,28 \%$ & $0,22 \%$ & $-1,27$ & 205 & 1,97 & 2,60 & 0,2073 \\
\hline & 0,10 & $0,11 \%$ & $0,24 \%$ & 0,47 & 205 & 1,97 & 2,60 & 0,6382 \\
\hline & 0,1 & $0,23 \%$ & $0,10 \%$ & 2,29 & 205 & 1,97 & 2,60 & 0,0231 \\
\hline & 2,10 & $-0,12 \%$ & $0,21 \%$ & $-0,56$ & 205 & 1,97 & 2,60 & 0,5771 \\
\hline \multirow{5}{*}{ Semleges hír } & $-10,10$ & $-1,08 \%$ & $0,51 \%$ & $-2,13$ & 205 & 1,97 & 2,60 & 0,0342 \\
\hline & $-10-1$ & $-0,04 \%$ & $0,35 \%$ & $-0,11$ & 205 & 1,97 & 2,60 & 0,9132 \\
\hline & 0,10 & $-1,04 \%$ & $0,37 \%$ & $-2,84$ & 205 & 1,97 & 2,60 & 0,0049 \\
\hline & 0,1 & $-0,91 \%$ & $0,16 \%$ & $-5,87$ & 205 & 1,97 & 2,60 & 0,0000 \\
\hline & 2,10 & $-0,12 \%$ & $0,33 \%$ & $-0,38$ & 205 & 1,97 & 2,60 & 0,7066 \\
\hline \multirow{5}{*}{ Rosszhír } & $-10,10$ & $-3,27 \%$ & $0,92 \%$ & $-3,54$ & 205 & 1,97 & 2,60 & 0,0005 \\
\hline & $-10-1$ & $0,08 \%$ & $0,64 \%$ & 0,13 & 205 & 1,97 & 2,60 & 0,8977 \\
\hline & 0,10 & $-3,36 \%$ & $0,67 \%$ & $-5,02$ & 205 & 1,97 & 2,60 & 0,0000 \\
\hline & 0,1 & $-2,89 \%$ & $0,29 \%$ & $-10,12$ & 205 & 1,97 & 2,60 & 0,0000 \\
\hline & 2,10 & $-0,47 \%$ & $0,61 \%$ & $-0,78$ & 205 & 1,97 & 2,60 & 0,4390 \\
\hline \multirow{5}{*}{ Nagyon rosszhír } & $-10,10$ & $-1,73 \%$ & $0,68 \%$ & $-2,54$ & 90 & 1,99 & 2,63 & 0,0128 \\
\hline & $-10-1$ & $0,26 \%$ & $0,47 \%$ & 0,55 & 90 & 1,99 & 2,63 & 0,5819 \\
\hline & 0,10 & $-1,99 \%$ & $0,49 \%$ & $-4,04$ & 90 & 1,99 & 2,63 & 0,0001 \\
\hline & 0,1 & $-1,51 \%$ & $0,21 \%$ & $-7,19$ & 90 & 1,99 & 2,63 & 0,0000 \\
\hline & 2,10 & $-0,48 \%$ & $0,45 \%$ & $-1,07$ & 90 & 1,99 & 2,63 & 0,2865 \\
\hline
\end{tabular}

\section{1. táblázat: Az S\&P 500 indexből vett minta kumulatív átlagos abnormális hozamai és} ezen hozamok szórásai, tesztstatisztikák, kritikus értékek és p-értékek az öt hírcsoport, és különböző időintervallumok esetén.

A negyedéves jelentés közzétételének napjától számított 11 napos $(0,10)$ intervallumon rendre magasabb $t$-statisztikákat kapunk eredményül, azaz ezen az intervallumon a jó hírek csoportját leszámítva minden csoportban minden szokásos szignifikancia szinten szignifikánsan tér el 0-tól a kumulált abnormális hozam.

A jelentéseket megelőző 10 napos (-10,-1) intervallumon arra kapunk választ, hogy vajon van-e a bennfentes információknak kiszivárgása, amely nyomot is hagy az abnormális hozamok formájában. Ezt az állítást mindegyik kategória esetében el lehet utasítani, ugyanis nem találunk 0-tól szignifikánsan különböző kumulált abnormális hozamokat ezen az intervallumon.

A $(0,1)$ intervallumon a várakozásoknak megfelelő irányú és szignifikáns abnormális hozamokat találunk mindegyik csoportban, bár a semleges hírek csoportjában itt is szignifikáns és negatív irányú a kumulált abnormális hozam. 
A $(2,10)$ időszakot vizsgálva arra kaphatunk választ, hogy kialakul-e az eseményt követő kereskedési napokon momentum. Az eredmények alapján a nagyon jó hírek csoportjában látunk szignifikáns abnormális hozamokat és így trendet ezen az időtávon, ugyanakkor annak iránya a bejelentés irányával ellentétes, azaz szignifikáns árkorrekció, nem pedig a bejelentés hatására kialakult trend az, amit megfigyelhetünk. A jó, a semleges, a rossz és a nagyon rossz hírek esetén minden szokásos szignifikancia szinten egyértelmüen el lehet utasítani a kialakult momentum létét.

Az S\&P 500 IT mintájának táblázatát áttanulmányozva hasonló eredményekre juthatunk (12. táblázat). A $(-10,10)$ intervallumot tekintve az S\&P 500 indexhez hasonlóan itt is szignifikáns kumulált abnormális hozamokat látunk a nagyon jó, a semleges, a rossz és a nagyon rossz hírcsoportokban, míg a jó hírek esetén itt sem szignifikáns a hozam. A kumulált abnormális hozamok szintje magasabb az S\&P 500 indexnél látottnál a nagyon jó hírek, a semleges hírek, és a nagyon rossz hírek csoportjában, míg hozzávetőleg azonos a mértéke a jó és a rossz hírek esetén. Szemben az S\&P 500 index esetével, ennél az indexnél a nagyon rossz hírek kumulált abnormális hozamai nagyobb mértéküek a rossz hírcsoport esetén tapasztaltnál. A kumulált abnormális hozamok szintje, valamint iránya és a meglepetés nagysága között itt még jobban látszik a pozitív összefüggés: a meglepetés iránya általában meghatározza a kumulált abnormális hozamok irányát, és minél nagyobb a meglepetés nagysága, annál nagyobb a tapasztalt kumulált abnormális hozam is. Itt is látszik az eltolódás a negatív ár-reakciók irányába a hírcsoportok között: a nagyon jó hírek esetén 1,63\% a kumulált abnormális hozam, a jó hírekre gyakorlatilag nincs elmozdulás, a kimutatott - $0,11 \%$ nem különbözik szignifikánsan 0-tól, a semleges hírekre $-1,86 \%$ a kumulált abnormális hozamok mértéke, míg a rossz és nagyon rossz hírek esetében pedig $-3,3 \%$ és $-6,63 \%$.

A negyedéves jelentés közzétételének napjától számított 11 napos $(0,10)$ intervallum esetén szignifikáns az abnormális hozam a nagyon jó hírek, a rossz és a nagyon rossz hírek esetén és inszignifikáns a jó hírek esetén hasonlóan az S\&P 500 indexnél látottakhoz, ugyanakkor itt már nem szignifikáns a semleges hírcsoport esetén. 
A $(0,1)$ intervallumon minden csoportban szignifikáns kumulált abnormális hozamot látunk az S\&P 500 indexhez hasonlóan, kivéve a jó hírcsoportot, ahol nincs szignifikáns kumulált abnormális hozam ezen az intervallumon.

\begin{tabular}{|c|c|c|c|c|c|c|c|c|}
\hline S\&P 500 IT & $\overline{\tau_{1}, \tau_{2}}$ & CAR & $s$ & $\theta$ & Szabadságfok & $t_{0,975}$ & $t_{0,995}$ & $\bar{p}$ \\
\hline \multirow{5}{*}{ Nagyon jó hír } & $-10,10$ & $1,63 \%$ & $0,33 \%$ & 4,95 & 410 & 1,97 & 2,59 & 0,0000 \\
\hline & $-10-1$ & $0,16 \%$ & $0,23 \%$ & 0,69 & 410 & 1,97 & 2,59 & 0,4895 \\
\hline & 0,10 & $1,48 \%$ & $0,24 \%$ & 6,18 & 410 & 1,97 & 2,59 & 0,0000 \\
\hline & 0,1 & $1,44 \%$ & $0,10 \%$ & 14,13 & 410 & 1,97 & 2,59 & 0,0000 \\
\hline & 2,10 & $0,04 \%$ & $0,22 \%$ & 0,17 & 410 & 1,97 & 2,59 & 0,8661 \\
\hline \multirow{5}{*}{ Jó hír } & $-10,10$ & $-0,11 \%$ & $0,47 \%$ & $-0,22$ & 192 & 1,97 & 2,60 & 0,8235 \\
\hline & $-10-1$ & $-0,15 \%$ & $0,32 \%$ & $-0,45$ & 192 & 1,97 & 2,60 & 0,6512 \\
\hline & 0,10 & $0,04 \%$ & $0,34 \%$ & 0,12 & 192 & 1,97 & 2,60 & 0,9022 \\
\hline & 0,1 & $-0,01 \%$ & $0,15 \%$ & $-0,07$ & 192 & 1,97 & 2,60 & 0,9405 \\
\hline & 2,10 & $0,05 \%$ & $0,31 \%$ & 0,17 & 192 & 1,97 & 2,60 & 0,8642 \\
\hline \multirow{5}{*}{ Semleges hír } & $-10,10$ & $-1,86 \%$ & $0,70 \%$ & $-2,65$ & 74 & 1,99 & 2,64 & 0,0098 \\
\hline & $-10-1$ & $-1,25 \%$ & $0,48 \%$ & $-2,57$ & 74 & 1,99 & 2,64 & 0,0121 \\
\hline & 0,10 & $-0,62 \%$ & $0,51 \%$ & $-1,21$ & 74 & 1,99 & 2,64 & 0,2298 \\
\hline & 0,1 & $-0,45 \%$ & $0,22 \%$ & $-2,07$ & 74 & 1,99 & 2,64 & 0,0418 \\
\hline & 2,10 & $-0,17 \%$ & $0,46 \%$ & $-0,36$ & 74 & 1,99 & 2,64 & 0,7183 \\
\hline \multirow{5}{*}{ Rosszhír } & $-10,10$ & $-3,30 \%$ & $1,20 \%$ & $-2,74$ & 25 & 2,06 & 2,79 & 0,0111 \\
\hline & $-10-1$ & $-0,44 \%$ & $0,83 \%$ & $-0,53$ & 25 & 2,06 & 2,79 & 0,6035 \\
\hline & 0,10 & $-2,86 \%$ & $0,87 \%$ & $-3,29$ & 25 & 2,06 & 2,79 & 0,0030 \\
\hline & 0,1 & $-2,75 \%$ & $0,37 \%$ & $-7,39$ & 25 & 2,06 & 2,79 & 0,0000 \\
\hline & 2,10 & $-0,12 \%$ & $0,79 \%$ & $-0,15$ & 25 & 2,06 & 2,79 & 0,8837 \\
\hline \multirow{5}{*}{ Nagyon rosszhír } & $-10,10$ & $-6,63 \%$ & $1,60 \%$ & $-4,15$ & 14 & 2,14 & 2,98 & 0,0010 \\
\hline & $-10-1$ & $-2,26 \%$ & $1,10 \%$ & $-2,05$ & 14 & 2,14 & 2,98 & 0,0597 \\
\hline & 0,10 & $-4,37 \%$ & $1,16 \%$ & $-3,78$ & 14 & 2,14 & 2,98 & 0,0020 \\
\hline & 0,1 & $-6,03 \%$ & $0,49 \%$ & $-12,24$ & 14 & 2,14 & 2,98 & 0,0000 \\
\hline & 2,10 & $1,66 \%$ & $1,05 \%$ & 1,59 & 14 & 2,14 & 2,98 & 0,1339 \\
\hline
\end{tabular}

12. táblázat: Az S\&P 500 IT indexből vett minta kumulatív átlagos abnormális hozamai és ezen hozamok szórásai, tesztstatisztikák, kritikus értékek és $p$-értékek az öt hírcsoport, és különböző időintervallumok esetén.

A jelentéseket megelőző 10 napos $(-10,-1)$ intervallumon csak a semleges hírek csoportjában találunk szignifikáns abnormális hozamot. A vállalati jelentéseket követő gyors ár-reakció utáni időszak a $(2,10)$ intervallumon nem mutat szignifikáns abnormális hozamokat, azaz nem alakul ki trend a jelentést követő napokban (szemben az S\&P 500 esetén tapasztalttal itt nincs árkorrekció a nagyon jó hírek csoportjában). 
Összefoglalva a bemutatott eredményeket:

- Az S\&P 500 és az S\&P 500 IT indexek esetében a teljes eseményablak $(-10,10)$ intervallumán szignifikáns kumulált abnormális hozamokat találunk a nagyon jó, a rossz, a semleges és a nagyon rossz hírek esetén, viszont a jó hírek esetében nincs szignifikáns kumulált abnormális hozam. A kumulált abnormális hozamok iránya és szintje, valamint a tapasztalt meglepetés iránya és nagysága között pozitív kapcsolat figyelhető meg eltolódással a negatív ár-reakciók irányába, mivel míg a nagyon jó hírek csoportjában az S\&P 500 esetén $+0,77 \%$ a kumulált abnormális hozam, addig a semleges hírekhez már -1,08\%-os negatív kumulált abnormális hozam társul, a rossz és nagyon rossz hírcsoportokhoz pedig $-3,27 \%$ és $-1,73 \%$. Feltételezhetően a tapasztalt szignifikáns ár-reakciók mögött az húzódik meg, hogy a 2008-as nagy világgazdasági sokkot követő gazdasági felívelést jellemző emelkedő részvényárakkal leírható trendben a piaci szereplők vállalatok jelentéseivel szembeni elvárásai magasan vannak és még a +/-1\%-os sávba eső EPS-meglepetéseket is negatív hírként értékelik. Az S\&P 500 IT index esetében a kumulált abnormális hozamok szintje magasabb az S\&P 500 indexnél látottnál a nagyon jó hírek, a semleges hírek, és a nagyon rossz hírek csoportjában, míg hozzávetőleg azonos a mértéke a jó és a rossz hírek esetén.

- A $(0,1)$ intervallumon mindkét index esetében és mindegyik hírcsoportban a meglepetés irányának megfelelő szignifikáns kumulált abnormális hozamokat találunk. A semleges hírek esetén a befektetői csalódottságnak betudható negatív hozam ezen az intervallumon is jelen van, és kivételt jelent az S\&P 500 IT index jó hírcsoportja, ahol 0-tól nem különbözik szignifikánsan a kumulált abnormális hozam.

- A vállalati eredmények közzétételekor megfigyelhető azonnali és szignifikáns ár-reakciót követő időszak a $(2,10)$ intervallumon csak az S\&P500 index nagyon jó hírek csoportjában mutat szignifikáns kumulált abnormális hozamot, ugyanakkor annak iránya a bejelentés irányával ellentétes. Azaz szignifikáns árkorrekció, nem pedig a bejelentés hatására kialakult trend az, amit megfigyelhetünk. Az S\&P500 semleges és rossz hírek csoportjai, illetve az S\&P500 IT index minden csoportjának esetében ezzel szemben nem találunk szignifikáns abnormális hozamokat ezen az időtávon, tehát az új információ már 
a bejelentést követő napon szinte teljesen beárazódik. Így az elemzés összességében azt támasztja alá, hogy a kiválasztott mintában lévő részvények piaca közepesen hatékony.

- Az 1-es hipotézis első állítását elfogadjuk:

- A vállalatok profitabilitásában jelentkező meglepetés iránya és nagysága határozza meg azt, hogy hogyan módosulnak a részvényárfolyamok a bejelentés hatására. Ugyanakkor eltolódás figyelhető meg az egyes hírcsoportok esetén érzékelt kumulált abnormális hozamok szintjében és irányában a negatív árreakciók irányába, mivel szignifikáns pozitív hozam csak a nagyon jó hírek csoportjában jelentkezik, míg a jó hírek csoportjában már nincs 0-tól szignifikánsan különböző hozam, míg a semleges hírek csoportjában már negatív kumulált abnormális hozamokat látunk, ám a rossz és nagyon rossz hírek csoportjában annak mértéke meghaladja a semleges csoportnál tapasztaltat.

- Az 1-es hipotézis második állítását elvetjük: az új információ hatása a bejelentést követő kereskedési napokon már nem figyelhető meg és nem alakul ki a meglepetés irányának megfelelő trend.

\subsubsection{Különbözőségek az EPS meglepetés hatásában}

A második hipotézisünk tesztelését tartalmazza ez az alfejezet. Ezen hipotézis szerint a technológiai szektorban nem azonosak a meglepetés hatására megfigyelhető kumulatív átlagos abnormális hozamok a másik minta értékeivel, és a technológiai részvények esetén nagyobb a nullától való eltérés. Ezt a feltételezést arra alapoztuk, hogy vélhetően bizonytalanabb az iparágban a vállalatok értékelése, így a részvény piaci ára ideiglenesen távolabb kerülhet az indokolt valós értékétől, illetve az EPS-tény adatok valószínűleg nagyobb szórást mutatnak az elemzői konszenzusoktól.

Annak tesztelésére, hogy a két minta hírcsoportjaiban a kumulatív átlagos abnormális hozamok egymástól szignifikánsan különböznek-e kétmintás $t$-próba használható. A két független mintás próbák módszertani részleteit, tesztstatisztikáinak számításait Hunyadi és Vita (2008) könyvének 7. fejezete alapján végeztük. 
A két minta varianciái statisztikailag eltérőnek bizonyultak, így a kétmintás $t$-próbát a (10,10) intervallumon mért kumulatív abnormális hozamokra alkalmazzuk. Ez esetben a következő hipotézispárt vizsgáljuk:

$$
\begin{aligned}
& H_{0}: \overline{C A R}_{S P}(-10,10)=\overline{C A R}_{S P I T}(-10,10), \\
& H_{1}: \overline{C A R}_{S P}(-10,10) \neq \overline{C A R}_{S P I T}(-10,10),
\end{aligned}
$$

ahol az alsóindexek az adott részvényindexböl vett mintára utalnak, és ebben az esetben is páronként hasonlítjuk össze a pozitív, illetve negatív EPS jelentések kategóriáit. Ebben az esetben a $t$-statisztikák az alábbi képlet segítségével számolhatók ki:

$$
t=\frac{\overline{C A R}_{S P}(-10,10)-\overline{C A R}_{S P I T}(-10,10)}{\sqrt{s_{S P}^{2} / N_{S P}+s_{S P I T}^{2} / N_{S P I T}}},
$$

ahol $N_{S P}$ és $N_{S P I T}$ a megfelelő indexek vizsgált kategóriájában lévő elemszám.

\begin{tabular}{|l|r|c|r|r|c|}
\hline & \multicolumn{1}{|c|}{$t$-stat } & szabadságfok & \multicolumn{1}{c|}{$t_{0,975}$} & \multicolumn{1}{c|}{$t_{0,995}$} & $p$ \\
\hline Nagyon Jó hír & $-37,08$ & 726,1 & $-1,96$ & 1,96 & 0,0000 \\
\hline Jó hír & $-1,66$ & 338,6 & $-1,97$ & 1,97 & 0,0971 \\
\hline Semleges hír & 8,09 & 131,1 & $-1,98$ & 1,98 & 0,0000 \\
\hline Rossz hír & 0,10 & 46,6 & $-2,01$ & 2,01 & 0,9234 \\
\hline $\begin{array}{l}\text { Nagyon Rossz } \\
\text { hír }\end{array}$ & 11,63 & 15,2 & $-2,13$ & 2,13 & 0,0000 \\
\hline
\end{tabular}

13. táblázat: Az S\&P 500 és az S\&P 500 IT indexből vett minták kumulatív átlagos abnormális hozamai közötti eltérés t-statisztikái az öt hírcsoport esetén a $(-10,10)$ intervallumon.

A 13. táblázat $t$-statisztikái alapján a nullhipotézist elutasítjuk, a nagyon jó, a nagyon rossz és a semleges hírek csoportjaiban szignifikáns eltérés mutatkozik az S\&P500 és S\&P500 IT indexek negyedéves jelentéseket övező kumulált abnormális hozamai között a szokásos szignifikancia szinteken, és az S\&P500 IT hírcsoportjaiban nagyobb a kumulált abnormális hozamok mértéke a két index közül. A jó, illetve a rossz hírek csoportjában nincs érdemi különbség a tapasztalt abnormális hozamok nagyságában a két index között. A jó hírek csoportjával kapcsolatban ez nem meglepö fejlemény annak tükrében, hogy mindkét esetben 0-tól szignifikánsan nem eltérő hozamokat láttunk az 
elemzés korábbi részében ebben a hírcsoportban, illetve, ha figyelembe vesszük, hogy a negatív ár-reakciók irányába történő eltolódás miatt ez a hírcsoport számít az origónak a hírcsoportok között. A rossz hírek csoportjában talált kumulált abnormális hozam szintbeli egyezésére ugyanakkor nem rendelkezünk magyarázattal. Az eredmények alapján összességében elfogadjuk a fejezetben megfogalmazott 2-es hipotézist arról, hogy a technológiai szektorban erőteljesebb a meglepetés hatása az árfolyamokra az általános részvénypiacnál tapasztalthoz viszonyítva. 


\subsection{A MAGYAR ABSZOLÚT HOZAMÚ BEFEKTETÉSI ALAPOK HOZAMAINAK ELEMZÉSE AZ MBTM-EK SEGÍTSÉGÉVEL, ÉS A HOZAMMANIPULÁCIÓ NYOMAINAK KIMUTATÁSA}

Ebben a fejezetben saját számításokon mutatjuk be magyarországi abszolút hozamú befektetési alapok értékelését, és a hozammanipuláció nyomainak kimutatását új eredményként, mivel nem ismerünk példát a hozammanipuláció nyomainak kimutatásra a szakirodalomban magyar befektetési alapok esetén. A fejezetben leírtak két cikkünkből, (Rácz 2019a, 2019b) merítettek sokat.

Az alábbi új eredményeink születtek az elemzésünk során:

1) A Sharpe-ráta eredményeit összevetettük az MBTM eredményeivel és a rangkorreláció alapján kimutattuk bizonyos mértékű hozammanipulációnak a nyomait.

2) Új eredményként bemutattuk a különféle MBTM-verziók közötti érték és rangsor béli különbségeket, és azok lehetséges okát.

3) Újításként javasoljuk a pontossága miatt az Ingersoll et al. (2007)-féle MBTM alkalmazását a Brown et al. (2010)-féle MBTM-el szemben mind a teljesítmény értékeléshez, mind a Kételkedési Hányados számításához.

4) Elemeztük az MBTM-re épülő Kételkedési Hányados jelzőképességét a hozammanipuláció vagy szuboptimális befektetési döntések feltárásában, valamint viszonyulását az alternatív módszerekhez, a Torzítási Rátához, és a Diszkontinuitás-elemzéshez.

i. A Kételkedési Hányadosnak a szakirodalomban megfigyelt, az alternatív hozammanipulációt kimutató módszerekkel való szoros átfedésével (Brown et al. (2010) alapján 80\%-os egyezés) szemben az elemzett mintánkon felemás eredmények születtek, mivel az alternatív módszerek a 31 befektetési alapból 10 esetben jeleztek anomáliát, azaz hozammanipulációt nagy valószínüséggel, míg a Kételkedési 
Hányados csak 4 befektetési alapot jelölt meg gyanúsnak. Előbbi esetében 4, utóbbi esetében 1-esetben találtuk jelét Diszkontinuitásnak is a 0 körüli kockázattal korrigált hozamokban.

ii. Összességében tehát az eredményeink szerint a Torzítási Ráta jobb előszürő eszköznek bizonyult a hozammanipuláció részletesebb elemzéséhez (pl. Diszkontinuitás-elemzéssel), mint a Kételkedési Hányados.

iii. Mindössze egy befektetési alap, a Concorde Citadella esetében tüntek megalapozottnak a gyanús jelzések a befektetési politikák és a befektetési alapkezelőkkel folytatott interjúk alapján, és ezt az alapot mind a Kételkedési Hányados, mind a Torzítási Ráta megjelölte. Ezen alap esetében megalapozottnak tünik az időnként szuboptimális befektetési döntések miatti torzítás megléte a befektetési politika ismeretében.

\subsubsection{Az elemzés elvégzéséhez szükséges elemek kezelése}

Ebben az alfejezetben bemutatjuk az elemzéshez szükséges elemek kezelését, valamint az MBTM számításának lépéseit az Ingersoll et al. (2007), valamint a Brown et al. (2010) képletének alkalmazásakor.

31 olyan befektetési alapot választottunk ki az elemzés számára (lásd 14. táblázat), amelyek az abszolút hozamú befektetési alapok kategóriájába tartoznak, magyar forintban vannak denominálva, van legalább 7 éves folyamatos kereskedési múltjuk, és a hozamadataik elérhetőek a BAMOSZ (Befektetési Alapkezelők és Vagyonkezelők Magyarországi Szövetsége) honlapján ${ }^{6}$. Az elemzési periódusnak a 2010.04.28. és 2017.04.27. közötti időszakot választottuk, amely 55056 napi hozamot ölelt fel.

\footnotetext{
${ }^{6}$ http://www.bamosz.hu/
} 


\begin{tabular}{|c|c|c|}
\hline Sorszám & Alap neve & Alap ISIN kódja \\
\hline $1 /$ & Aberdeen Diversified Growth Alapok Alapja I & HU0000704556 \\
\hline 2 & AEGON Alfa & HU0000703970 \\
\hline 31 & Aegon MoneyMaxx A & HU0000703145 \\
\hline 4 & Aegon ÓzonMaxx & HU0000705157 \\
\hline 5 & AEGON Smart Money & HU0000708169 \\
\hline 6 & Budapest Kontroll Alap A & HU0000702741 \\
\hline 7 ( & Citadella Származtatott & HU0000707948 \\
\hline 8 & Concorde Columbus & HU0000705702 \\
\hline 9 & Concorde PB2 & HU0000704705 \\
\hline 10 & Concorde Rubicon & HU0000707252 \\
\hline 11( & Concorde VM & HU0000703749 \\
\hline 12 & Erste DPM Alternativ & HU0000705314 \\
\hline 13 & Erste Multistrategy Abszolút Hozamú Alapok Alapja & HU0000705322 \\
\hline 14( & Generali IPO & HU0000706791 \\
\hline 15 & Generali Spirit & HU0000706833 \\
\hline 16 & Generali Titanium Abszolút Alapok Alapja & HU0000706817 \\
\hline 17( & OTP Abszolút Hozam A & HU0000704457 \\
\hline 18 & OTP EMDA & HU0000706361 \\
\hline 19 & OTP G10 Euro A & HU0000706221 \\
\hline 20 & OTP Supra & HU0000706379 \\
\hline 21( & OTP Új Európa Alap A & HU0000705827 \\
\hline 22 & Platina Alfa & HU0000704648 \\
\hline 23 & Platina Beta & HU0000704655 \\
\hline 24 & Platina Delta A & HU0000704671 \\
\hline 25 & Platina Gamma & HU0000704663 \\
\hline 26 & Platina PíA & HU0000704689 \\
\hline 27 & Raiffeisen Hozam Prémium Alap A & HU0000703699 \\
\hline 28 & Raiffeisen Index Premium & HU0000703707 \\
\hline 291 & Raiffeisen Private Pannonia Alapok Alapja A & HU0000705231 \\
\hline 30 & Sovereign PB Származtatott & HU0000707732 \\
\hline 31$]$ & Takarek Invest Abszolút Hozamú Alap & HU0000707997 \\
\hline
\end{tabular}

14. táblázat: A kiválasztott abszolút hozamú alapok.

\section{A kockázatmentes hozam $\left(\mathbf{r}_{\mathrm{ft}}\right)$ kezelése}

Kockázatmentes hozamnak az RMAX index referencia hozamának alakulását használtuk, mivel ez a rövidlejáratú állampapírhozam nem csak kockázatmentesnek tekinthető, de jól tükrözi az elemzett időszakban a kockázatmentes hozam lényeges változásait is, és a mintában elemzett befektetési alapok többsége ezt tekinti a kockázatmentes referencia hozamnak. A Sharpe-rátához a teljes időszakra számított átlaghozamot használtuk, amire évesített 4,67\% adódott. Az MBTM számításához a RMAX index referencia hozamának napi változásait vettük figyelembe. Az adott időszaki napi folytonosan számított kockázatmentes hozam kiszámításához arányosítani 
kell RMAX index évesített referencia hozamáról napi hozamra, 250 kereskedési nappal számolva az alábbi képlet szerint:

$$
r_{f t(\text { folytonos })}=\frac{\ln \left(\frac{1+r_{f t}}{1}\right)}{250}
$$

\section{Az alapok hozamainak $\left(r_{t}\right)$ kezelése}

A BAMOSZ honlapjáról a napi árfolyam adatokat letöltve az alábbi képlettel lehet meghatározni a napi loghozamokat:

$$
r_{t}=\ln \left(\frac{P_{t}}{P_{t-1}}\right)
$$

\section{Az MBTM értékének meghatározása Ingersoll et al. (2007) képletének segítségével}

Az Ingersoll et al. (2007) által definiált MBTM (Lásd (14)) értékéinek meghatározását el kell végezni $\rho=2, \rho=3$ és $\rho=4$ esetben is. Mindhárom esetben első lépésben az adott időszaki hozam kockázatmentes hozam feletti többletét 1- $\rho$-adik hatványra kell emelni, így a hozamarányt a kockázattal korrigálni:

$$
\text { Kockázattal korrigált többlethozam }=\left(\frac{1+r_{t}}{1+r_{f t}}\right)^{1-\rho} \text {. }
$$

Majd a kockázattal korrigált többlethozamok teljes időszakra számított átlagának vesszük a logaritmusát, és elosztjuk 1 - $\rho$-val.

$$
\frac{1}{(1-\rho)} \ln \left(\frac{1}{T} \sum_{t=1}^{T} \text { Kockázattal korrigált többlethozam }_{\mathrm{t}}\right)
$$

Utolsó lépésként évesítjük a napi hozamokra számított @̂ értékét, 250 kereskedési nappal felszorozva.

$$
\widehat{\Theta}_{\text {Ingersoll }}=\frac{1}{\Delta t} \hat{\Theta}_{\text {napi }}
$$

@̂ a befektetési alap kockázattal korrigált többlethozamára ad becslést. Másképpen egy adott $\widehat{\Theta}$ a portfóliónak az az értékszáma, amely megegyezik egy kockázatmentes 
eszköznek a folytonos hozamszámítással számított és évesített hozamával, ami $\widehat{\Theta}$ értékével haladja meg a kockázatmentes hozamot.

\section{Az MBTM értékének meghatározása Brown et al. (2010) képletének segítségével}

A Brown et al. (2010) által definiált megközelítésben az MBTM felírható a többlethozam átlagának és a többlethozam mintából számított varianciájának a különbségeként, ahol a varianciának az együtthatója (1- $\rho) / 2$ :

$$
\hat{\Theta}(\rho)=\frac{1}{\Delta t}\left[\bar{x}+\frac{1-\rho}{2}\left(s_{x}^{*}\right)^{2}\right] \text {. }
$$

Az MBTM tehát felírható a többlethozam átlagának és a többlethozam mintából számított varianciájának a különbségeként.

Így az MBTM Brown et al. (2010) kiszámításához első lépésben ki kell számítani a többlethozam átlagát, amit úgy kaphatunk meg, ha kiszámítjuk a befektetési alap napi hozamának és a kockázatmentes hozam arányának logaritmusát minden napra.

$$
\text { Többlethozam }=\ln \left(\frac{1+r_{t}}{1+r_{f t}}\right) .
$$

Ezután a teljes időszakra vesszük ezek átlagát:

$$
\bar{x}=\frac{1}{T} \sum_{t=1}^{T} \text { Többlethozam }_{t} .
$$

A Brown et al. (2010)-féle megközelítésben a másik építő elem a többlethozam mintából számított varianciájának kiszámítása.

Végül a háromféle $\rho$-ra (2, 3 és 4) kiszámítjuk a két érték különbségét, ahol a szórásnégyzet együtthatója $(1-\rho) / 2$. Az így kapott napi $\widehat{\Theta}$ érték évesítéséhez a 250 kereskedési nappal felszorozva évesített hozamra arányosítunk

$$
\widehat{\Theta}_{\text {Brown }}=\frac{1}{\Delta t} \hat{\Theta}_{\text {napi }}
$$




\subsubsection{A Sharpe-ráta és az Ingersoll et al. (2007)-féle MBTM rangsorolásának összevetése}

Ebben az alfejezetben a Sharpe-rátához, mint klasszikus mutatószámhoz viszonyítva a rangkorreláció értékeiben megmutatkozó eltérések segítségével keressük a hozammanipuláció jeleit. A Sharpe-rátákat különféle kockázatelutasítási együtthatók mellett számított MBTM-ekhez hasonlítottuk. A rangkorrelációk viszonylag magas értéket vettek fel a 0,76-0,82-es sávban, ami ugyan magasabb a nemzetközi példákban látott 0,7 körüli értékeknél, de még mindig jelez annyi eltérést a klasszikus mutatószámokhoz viszonyítva, amelyet okozhat valamilyen szintű hozammanipuláció vagy hozamsimítás.

A rangkorreláció értékei arra utalnak, hogy van néhány alap, amelyek esetében komoly eltérés van a Sharpe-ráta szerinti rangsorolás és az MBTM szerinti rangsorolás, különösen 4-es kockázatelutasítás mellett (MBTM(4)):

- Az OTP G10 Euro tizenharmadik a Sharpe-ráta alapján, de csak harmincegyedik az MBTM(4) által rangsorolva,

- A Platina Delta tizennegyedik a Sharpe-ráta szerint, de csak a huszonkilencedik az MBTM(4) alapú rangsorban,

- A Raiffeisen Index Prémium huszonnyolcadik a Sharpe-alapú rangsorban, ám huszadik az MBTM(4) szerint,

- A Raiffeisen Hozam Prémium huszonkilencedik a Sharpe-ráta alapján rangsorban, viszont tizennyolcadik az $\operatorname{MBTM}(4)$ szerinti rangsorolásban.

\begin{tabular}{|l|r|}
\hline Sharpe-MBTM(2) & 0,8202 \\
\hline Sharpe-MBTM(3) & 0,8024 \\
\hline Sharpe-MBTM(4) & 0,7617 \\
\hline
\end{tabular}

15. táblázat: Rangkorrelációk a Sharpe-ráta és az MBTM között különböző kockázatelutasítási együtthatókra. 


\section{A 3-as kockázatelutasítási együtthatóval számított MBTM alapján legjobbnak és legrosszabbnak rangsorolt öt befektetési alap értékelése}

Az MBTM-szerint legjobbnak, valamint legrosszabbnak rangsorolt befektetési alapokat elemezve azt látjuk, hogy az MBTM-rangsorolás stabilnak mondható, mivel a különböző kockázatelutasítási együtthatókra közel azonos eredményeket ad - a rangkorreláció az MBTM különböző kockázatelutasítási együtthatóval számolt verziói között nagyon magas értékeket mutat a 0,97-0,99 tartományban. Ahogy a 16. táblázatban látható, a Sharpe-ráta és az MBTM alapú rangsorolás nagyobb eltérést mutat az $\operatorname{MBTM}(3)$ alapján legrosszabbnak értékelt alapok esetén, mint az $\operatorname{MBTM}(3)$ szerinti legjobbnak értékelt alapok esetében. Ennek leginkább az OTP G10 Euro alap az okozója, mert ahogy a 4. ábra kapcsán látszik, a Sharpe-ráta szerint tizenharmadik a sorban, míg az MBTM(3) alapján csak a harmincegyedik.

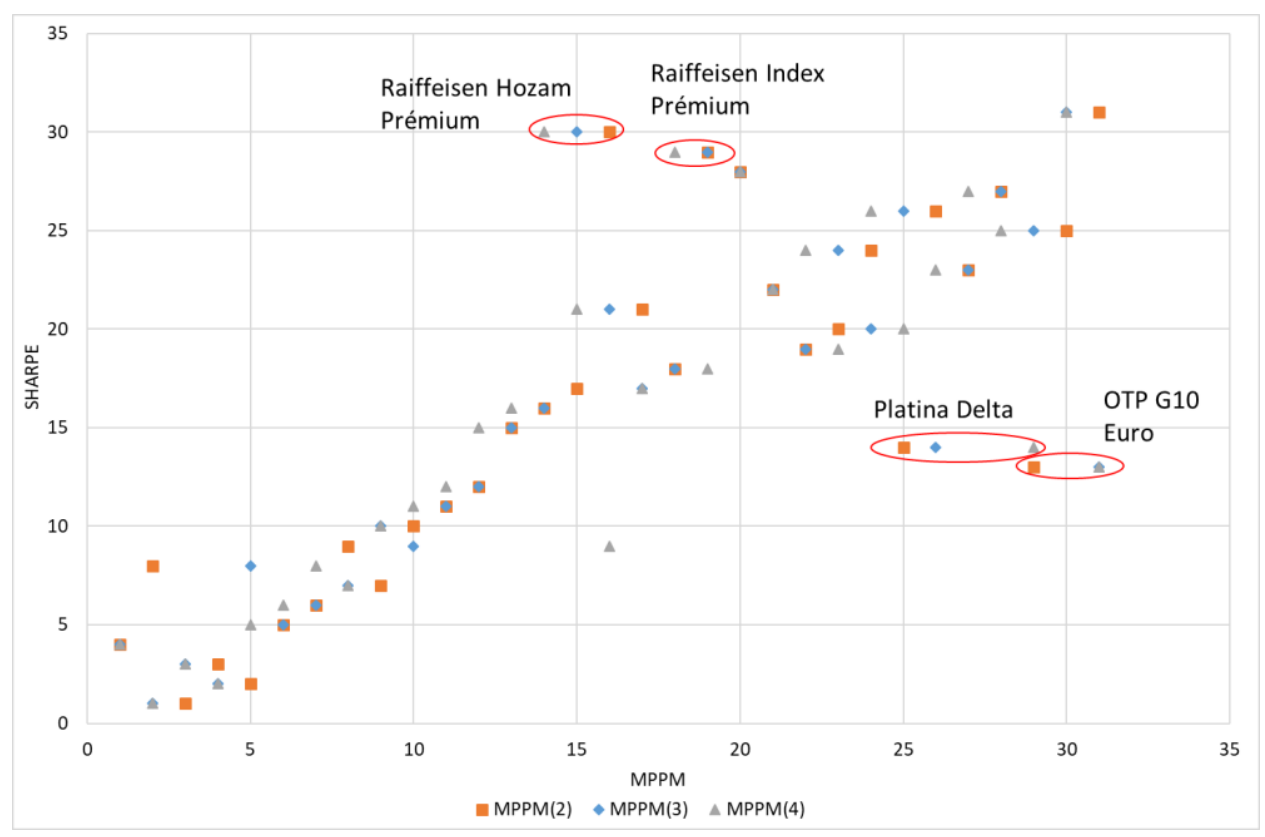

4. ábra: A Sharpe-ráta és az MBTM rangsorolásának összehasonlítása különböző kockázat-elutasítási együtthatók mellett. 
A Citadella Származtatott, Platina Pí, Platina Alfa rendre második, harmadik, negyedik az MBTM szerint, és rendre első, harmadik és második a Sharpe-ráta alapján. Ugyanakkor érdekes látni, hogy ezen befektetési alapok részesei a vizsgált alapok között a top 5 legmagasabb Kételkedési Hányados értékekkel bírók csoportjának. Bár a vizsgált alapok esetében a legmagasabb Kételkedési Hányadosok a 30-50-es sávban terülnek el, amely egyáltalán nem számít kiugró értéknek, de az látható, hogy az MBTM nem változik jelentősen a különböző kockázatelutasítási együtthatókra néhány alap esetében, azaz az implikált kockázatelutasítás relatíve magas.

A Concorde Rubicon első helyen rangsorolt a 3-as kockázatelutasítási együtthatóval számított MBTM szerint és negyedik a Sharpe-ráta rangsorában, míg az OTP Supra ötödik az MBTM rangsorában és nyolcadik a Sharpe-ráta alapján. Brown et al. (2010) szerint az MBTM a többlethozam átlagának és varianciájának a különbsége, és így kevésbé bünteti a szórást, mint a Sharpe-ráta. A Concorde Rubicon és az OTP Supra mind a legjobb ötbe tartozik az MBTM rangsorában, pedig az egyik legmagasabb szórással rendelkeznek a vizsgált mintában (huszonnegyedik és huszonnyolcadik legkevésbé biztonságosak a 31 befektetési alapból, ami azt jelenti, hogy csak hét, illetve három olyan alap van, aminek még ezeknél is magasabb a szórása). 


\begin{tabular}{|c|c|c|c|c|c|}
\hline 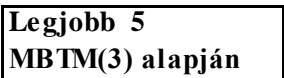 & \begin{tabular}{|c|} 
Concorde \\
Rubicon
\end{tabular} & Citadella & Platina Pí & $\begin{array}{c}\text { Platina } \\
\text { Alfa }\end{array}$ & $\begin{array}{c}\text { OTP } \\
\text { Supra }\end{array}$ \\
\hline Átlagos hozam & 10,84 & 4,00 & 9,40 & 9,21 & 13,36 \\
\hline rangsor & 3 & 4 & 5 & 6 & 2 \\
\hline Hozam szórás & 7,39 & 4,47 & 4,67 & 4,19 & 15,19 \\
\hline Hozam szórás rangsor & 24 & 12 & 14 & 10 & 28 \\
\hline Sharpe-ráta & 0,84 & 1,10 & 1,01 & 1,08 & 0,57 \\
\hline Sharpe-ráta rangsor & 4 & 1 & 3 & 2 & 8 \\
\hline $\operatorname{MBTM}(2)$ & 0,0549 & 0,0477 & 0,0454 & 0,0441 & 0,0513 \\
\hline $\operatorname{MBTM}(3)$ & 0,0522 & 0,0467 & 0,0443 & 0,0432 & 0,0386 \\
\hline MBT M(4) & 0,0495 & 0,0457 & 0,0432 & 0,0424 & 0,0259 \\
\hline Kételkedési Hányados & 22,16 & 49,81 & 43,68 & 52,43 & 6,04 \\
\hline $\begin{array}{l}\text { Kételkedési Hányados } \\
\text { rangsor }\end{array}$ & 26 & 30 & 28 & 31 & 21 \\
\hline MBT M(2) rangsor & 1 & 3 & 4 & 5 & 2 \\
\hline MBTM(3) rangsor & 1 & 2 & 3 & 4 & 5 \\
\hline MBTM(4) rangsor & 1 & 2 & 3 & 4 & 7 \\
\hline \begin{tabular}{|l|} 
Legrosszabb 5 \\
MBTM(3) alapján \\
\end{tabular} & \begin{tabular}{|c|} 
OTP G10 \\
Euro \\
\end{tabular} & $\begin{array}{c}\text { Sovereign } \\
\text { PB }\end{array}$ & $\begin{array}{c}\text { Generali } \\
\text { Spirit }\end{array}$ & $\begin{array}{c}\text { Multistrat } \\
\text { egy }\end{array}$ & $\begin{array}{l}\text { Generali } \\
\text { Titanium }\end{array}$ \\
\hline Átlagos hozam & 7,03 & $-1,17$ & 0,45 & 0,79 & 1,33 \\
\hline rangsor & 9 & 31 & 30 & 29 & 28 \\
\hline Hozam szórás & 22,07 & 5,76 & 6,95 & 5,60 & 6,96 \\
\hline Hozam szórás rangsor & 31 & 17 & 21 & 16 & 22 \\
\hline Sharpe-ráta & 0,11 & $-1,01$ & $-0,61$ & $-0,69$ & $-0,48$ \\
\hline Sharpe-ráta rangsor & 13 & 31 & 25 & 27 & 23 \\
\hline MBT M(2) & $-0,0477$ & $-0,0625$ & $-0,0481$ & $-0,0421$ & $-0,0393$ \\
\hline $\operatorname{MBTM}(3)$ & $-0,0719$ & $-0,0644$ & $-0,0505$ & $-0,0437$ & $-0,0418$ \\
\hline MBT M(4) & $-0,0961$ & $-0,0663$ & $-0,0529$ & $-0,0453$ & $-0,0443$ \\
\hline Kételkedési Hányados & 0,03 & $-30,76$ & $-17,66$ & $-24,79$ & $-13,99$ \\
\hline $\begin{array}{l}\text { Kételkedési Hányados } \\
\text { rangsor }\end{array}$ & 17 & 4 & 8 & 6 & 9 \\
\hline MBTM(2) rangsor & 29 & 31 & 30 & 28 & 27 \\
\hline MBTM(3) rangsor & 31 & 30 & 29 & 28 & 27 \\
\hline MBTM(4) rangsor & 31 & 30 & 28 & 27 & 26 \\
\hline
\end{tabular}

16. táblázat: Az MBTM alapján legjobbnak és legrosszabbnak rangsorolt alapok tulajdonságai. 


\subsubsection{A hozammanipuláció, hozamsimítás nyomainak kimutatása különböző módszerekkel}

Ebben az alfejezetben a hozammanipuláció, hozamsimítás vagy szuboptimális befektetési döntések miatti torzítás nyomait keressük különféle módszerekkel, a Kételkedési Hányados, a Torzítási Ráta, valamint a Diszkontinuitás-elemzés segítségével kiszürve azokat a befektetési alapokat, amelyek esetében a legmagasabb a valószínüsége ezeknek.

\section{A magas Kételkedési Hányadossal rendelkező befektetési alapok elemzése}

A Kételkedési Hányados és a Sharpe-ráta segítségével a csoportátlagtól vett eltérésük alapján a hozammanipulációval vagy szuboptimális befektetési döntések miatti torzítással legvalószínübben „gyanúsítható” befektetési alapok csoportját azonosítjuk. Brown et al. (2010) szerint a Kételkedési Hányados 150 körüli értéke már a lehetséges teljesítménymanipuláció, hozamsimítás vagy szuboptimális befektetési döntések jele. Az 5 legmagasabb Kételkedési Hányadossal rendelkező alapot láthatjuk a 17. táblázatban:

- Platina Alfa,

- Citadella Származtatott,

- Platina Béta,

- Platina Pí,

- Concorde Columbus.

A Kételkedési Hányados az 30-50-es sávban marad még ezen alapok esetében is, ami messze elmarad a gyanús jelzésnek számító 150-körüli értékektől, így ezen módszer alapján nem találtuk egyértelmủ nyomát hozammanipulációnak, vagy szuboptimális befektetési döntéseknek. 


\begin{tabular}{|c|c|c|c|c|c|}
\hline & $\begin{array}{c}\text { Platina } \\
\text { Alfa }\end{array}$ & Citadella & $\begin{array}{l}\text { Platina } \\
\text { Béta }\end{array}$ & Platina Pí & $\begin{array}{l}\text { Concorde } \\
\text { Columbus }\end{array}$ \\
\hline Átlagos hozam & 9,21 & 9,61 & 6,46 & 9,40 & 8,93 \\
\hline $\begin{array}{l}\text { Átlagos hozam } \\
\text { rangsor }\end{array}$ & 6 & 4 & 11 & 5 & 7 \\
\hline Hozam szórás & 4,19 & 4,47 & 2,78 & 4,67 & 5,30 \\
\hline Hozam szórás rangsor & 10 & 12 & 6 & 14 & 15 \\
\hline Sharpe-ráta & 1,08 & 1,10 & 0,65 & 1,01 & 0,80 \\
\hline Sharpe-ráta rangsor & 2 & 1 & 7 & 3 & 5 \\
\hline $\operatorname{MBTM}(2)$ & 0,04412 & 0,04774 & 0,01818 & 0,04537 & 0,03981 \\
\hline MBT M(3) & 0,04324 & 0,04674 & 0,01779 & 0,04429 & 0,03841 \\
\hline MBT M(4) & 0,04237 & 0,04574 & 0,01740 & 0,04320 & 0,03701 \\
\hline Kételkedési Hányados & 52,43 & 49,81 & 49,18 & 43,68 & 30,44 \\
\hline $\begin{array}{l}\text { Kételkedési Hányados } \\
\text { rangsor }\end{array}$ & 31 & 30 & 29 & 28 & 27 \\
\hline MBT M(2) rangsor & 5 & 3 & 9 & 4 & 6 \\
\hline MBT M(3) rangsor & 4 & 2 & 8 & 3 & 6 \\
\hline MBT M(4) rangsor & 4 & 2 & 8 & 3 & 5 \\
\hline
\end{tabular}

\section{7. táblázat: A legmagasabb Kételkedési Hányadossal rendelkező alapok tulajdonságai.}

Érdekességnek nevezhetjük azt, hogy a legmagasabb 5 Kételkedési Hányadossal rendelkező alapból négy, egyben a 7 legmagasabb Sharpe-rátával rendelkező alap is, illetve az MBTM szerint is a legjobban teljesítő 8 alap közé tartozik közülük. Így mindezeket figyelembe véve nem állíthatjuk azt sem, hogy hozammanipuláció vagy szuboptimális befektetési döntések okoznák ezen öt alap kiváló Sharpe-ráta eredményét és rangsorát. 


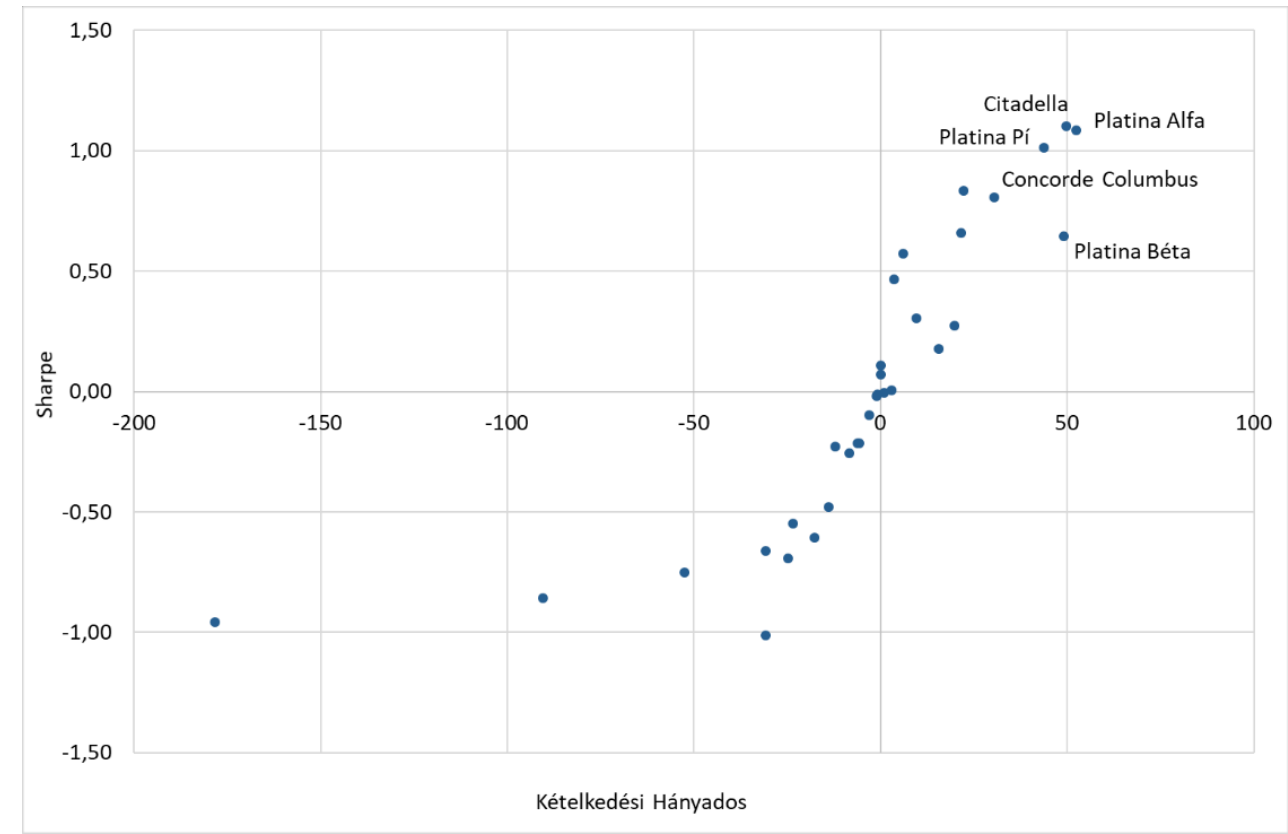

\section{5. ábra: A legmagasabb Kételkedési Hányadossal rendelkező alapok elemzése.}

Ugyanakkor a Sharpe-ráta-Kételkedési Hányados térben tekintve (lásd 5. ábra) ezen 5 befektetési alap outliernek tünik a kiugró értékeivel a többi megfigyelt befektetési alaphoz képest, így legalábbis indokoltnak tünik az óvatosság és további vizsgálatok végzése az esetükben.

\section{A hozammanipuláció kimutatása a Torzítási Ráta segítségével}

Alternatív technikaként a Torzítási Ráta értékeit is kiszámítottuk, hogy biztosabb képet kapjunk az esetlegesen hozamsimítást, hozammanipulációt vagy egyéb szuboptimális befektetési döntések miatti torzulást mutató befektetési alapokról. Mivel az elemzett befektetési alapok alapvetően a kockázatmentesnek tekintett RMAX-hozamot kívánják meghaladni, valamint közülük több befektetési alapra is jellemző lehet, hogy a kínálkozó befektetési lehetőségek felbukkanásáig kockázatmentes kötvénytípusú pozíciókban tartják a befektetéseiket, ezért jogos feltételezés, hogy nem a 0\%-os hozam meghaladása körül van esély anomáliák felfedezésére, hanem az RMAX-index aktuális időszaki hozamai körül (mivel a legtöbb elemzett befektetési alapunk ennek az indexnek a hozamát tekint benchmarknak). Ezen túl Abdulali (2006) is felhívja a figyelmet, hogy a Torzítási Ráta használata kevésbé megbízható olyan befektetési alapok vagy hedge fundok esetében, amelyek magas készpénzjellegü befektetésekkel rendelkeznek. Ennek 
megfelelően a Torzítási Ráta értékeit a kockázatmentes hozammal (helyettesítőjeként az RMAX-index hozamával) időszakonként korrigált (mivel az RMAX-index időszaki hozamai is ingadozást mutatnak) hozamokra számítottuk ki. Ezen túl elvégeztük a számításokat a kockázatmentes hozammal csökkentett, valamint a TER-rel (Total Expense Ratio - teljes költségráta) növelt hozamokra is. A két korrekcióval végzett számítás között ugyanakkor nem mutatkozott érdemi különbség a rangsort és következtetéseket tekintve, így a továbbiakban az RMAX-index hozamaival korrigált hozamokra számított Torzítási Ráta értékeit, valamint az eredmények értelmezését prezentáljuk.

A Torzítási Ráta értékei nagyrészt az 1,047 és 1,29 kvartilisek között összpontosulnak (lásd 6. ábra). Az átlag 1,23, míg a medián 1,165, a legkisebb érték 0,895, míg a legnagyobb 2,4.

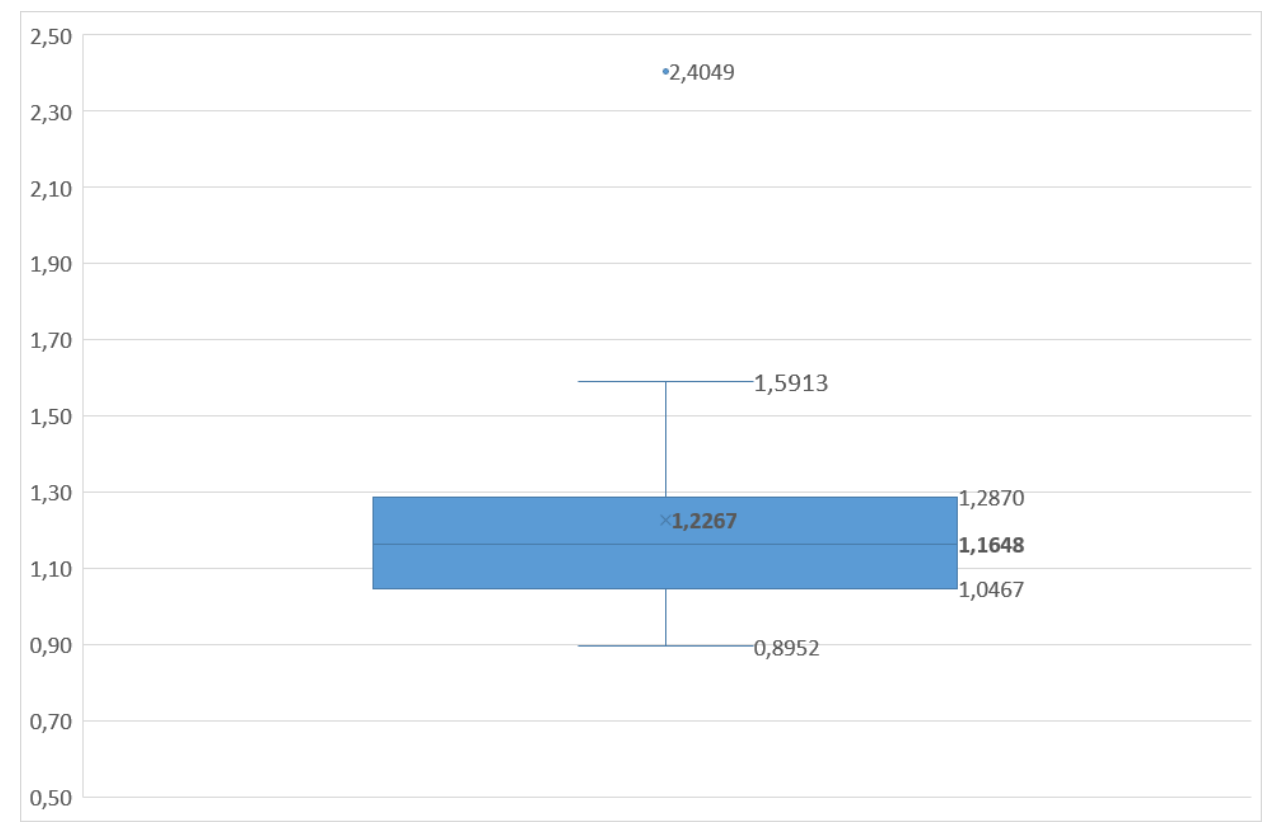

6. ábra: A Torzítási Ráta értékeinek megoszlása a vizsgált befektetési alapok esetében.

Abdulali (2006) szerint a Torzítási Rátát, mint az esetleges hozamsimítás vagy hozammanipuláció jelzőrendszerét, úgy érdemes használni, hogy az adott típusba tartozó befektetési alapok vagy hedge fundok közül azokat vetjük részletesebb vizsgálat alá, amelyek a csoport Torzítási Ráta medián értéke fölött helyezkednek el. Így Abdulali (2006) ajánlásait szigorúan követve a medián alapján 10, az átlag alapján 15 befektetési 
alapot lenne érdemes további vizsgálatoknak alávetni a hozamsimítás, egyéb hozammanipuláció, vagy szuboptimális befektetési döntések miatti torzulás nyomait keresve.

Ha csak azokra a befektetési alapokra összpontosítunk, amelyek kiugró értékekkel bírnak a csoport többi tagjához képest, akkor az 1,38-nál magasabb Torzítási Rátájú befektetési alapokat érdemes vizsgálni, amely az alábbi 6 alap:

Torzítási Ráta:

1. Aegon ÓzonMaxx: 2,4

2. Aegon MoneyMaxx: 1,59

3. Erste DPM 1,54

4. Raiffeisen Hozam Prémium: 1,56

5. Aegon Smart Money: 1,42

6. Citadella Származtatott: 1,38

Fontos ugyanakkor megjegyeznünk, hogy bármelyik kritikus értéket is választjuk, önmagában a Torzítási Ráta alapján nem tudjuk teljes bizonyossággal kijelenteni, hogy a kritikus érték fölötti befektetési alapok biztosan hozammanipulációt alkalmaznak vagy biztosan szuboptimális befektetési döntéseik miatti torzulást mutatnak, csak azt, hogy a kockázatmentes hozammal korrigálya eloszlásukban 0-körül az egy-egy szórásnyi intervallumban tapasztalható aránytalanság erősen felveti ennek a gyanúját.

\section{A Kételkedési Hányados és a Torzítási Ráta összevetése, Diszkontinuitás-elemzés}

Arra a kérdésre keressük a választ, hogy a Torzítási Ráta értékei és a Kételkedési Hányados értékei között milyen kapcsolat van, mennyiben fedi egymást a két módszer. Továbbá a Diszkontinuitás-elemzést felhasználva részletesebb értékelésnek vetjük alá a gyanúsnak előminősített befektetési alapok hozameloszlását (a Torzítási Rátához hasonlóan itt is az RMAX-index hozamaival korrigált hozamokat elemezve), hogy nagyobb bizonyosággal lehessen azonosítani a hozammanipuláció vagy szuboptimális befektetési döntések miatti torzulás jelenlétét. Az eredmények alapján a nemzetközi 
tapasztalatok ellenére, a Kételkedési Hányados kevésbé bizonyult megbízható előjelzőeszköznek, mint a Torzítási Ráta.

Ha grafikonon ábrázoljuk a befektetési alapokat a Torzítási Ráta és a Kételkedési Hányados szerint, akkor megfigyelhetjük, hogy a kiugró értékek tekintetében milyen a kapcsolat (lásd 7. ábra).

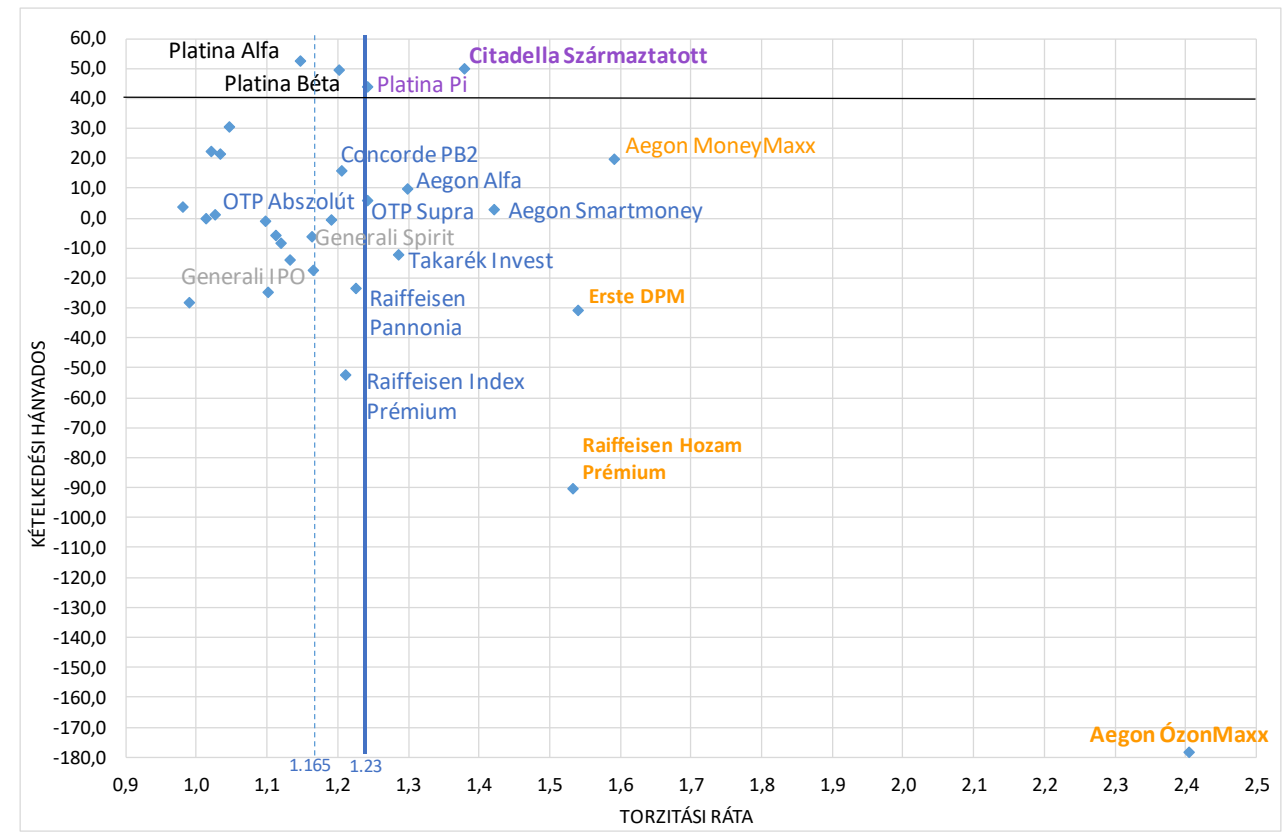

\section{7. ábra: A Torzítási Ráta és a Kételkedési Hányados értékeinek összehasonlítása.}

Habár a Kételkedési Hányados esetében az értékek elmaradtak a Brown et al. (2010) által kritikus értéknek meghatározott 150-körüli szintektől, így a mutató alapján egy befektetési alapról sem lehetett egyértelműen megállapítani a hozammanipuláció vagy szuboptimális befektetési döntések miatti torzítás fennálltát, volt 4 befektetési alap, amely kiugró értékekkel bírt a Sharpe-rátát is figyelembe véve a megfigyelt többi befektetési alaphoz képest (lásd 5. ábra). Ezek közül a Platina Pí, és a Citadella Származtatott rendelkezik a mediánnál is nagyobb Torzítási Ráta értékkel, így két módszer alapján is további elemzésre javasolt alapoknak tekinthetők a hozammanipuláció vagy szuboptimális befektetési döntések leshetőségét tekintve (lásd 7. ábra, lila színü felirattal). Ugyanakkor az előbbi befektetési alap a Torzítási ráta alapján még nem üt el látványosan a többi befektetési alap értékeitől. Az 5. ábra kapcsán leírtak, valamint a 7. ábra alapján úgy értékeljük, hogy Platina Alfa és Platina Béta 
befektetési alapokat csak a Kételkedési Hányados különbözteti meg a többi befektetési alaptól érdemben eltérő értékekkel (lásd 7. ábra, fekete felirattal), míg a Torzítási Ráta nem. Bár Abdulali (2006) átlag szabálya (lásd 7. ábra, 1,165-es érték szaggatott vonallal ábrázolva) alapján már indokolt részletesebb elemzésnek alávetni a Platina Béta alapot is a Torzítási Ráta alapján is.

Az Aegon ÓzonMaxx, Aegon MoneyMaxx, Erste DPM, és Raiffeisen Hozam Prémium narancssárga színủ felirattal szerepelnek (7. ábra), mivel ezeknek az 1,53-nál nagyobb Torzítási Rátái a csoporttól lényegesen kiugró értékei szerint a Torzítási Ráta potenciális hozammanipuláltság vagy szuboptimális befektetési döntések miatti torzítottság gyanújával különbözteti meg a többi befektetési alaptól, viszont a Kételkedési Hányados szerint nincsenek kiugró értékeik.

Abdulali (2006) alapján további vizsgálatnak érdemes alávetni azokat a befektetési alapokat, amelyeknek a Torzítási Ráta értékei meghaladják a megfigyelt csoport mediánját, amely esetükben az 1,23-as kritikus értéket, és 10 befektetési alapot jelent (míg, ha a Torzítási Ráta átlagát az 1,165-öt választjuk a kritikus értéknek, akkor 15 alapot). A befektetési alapok kockázatmentes hozammal (az RMAX-index hozamával) korrigált hozamainak a 0-körüli eloszlását vizsgáljuk a diszkontinuitás jeleit keresve, amelyek szintén a potenciális hozamsimítást tanúsíthatják. Elméletben, ha hozamsimítás, vagy az egyes illikvid eszközök kreatív értékelése áll a háttérben, akkor a közvetlenül 0 melletti pozitív és negatív hozamok gyakoriságát mutató oszlopokban/osztályokban aránytalanságot fedezhetünk fel a pozitív hozamok irányában.

Ennek megfelelően Diszkontinuitás-elemzés során a hisztogramok elkészítéséhez Bollen és Pool (2009)-t követve Silverman (1986) képletet használjuk:

$$
\mathrm{h}=0,9 \min \left[\sigma ; \frac{\mathrm{Q} 3-\mathrm{Q} 1}{1,34}\right] \mathrm{N}^{-0,2},
$$

ahol h az osztályok szélessége, $\sigma$ a hozamok szórása, $\mathrm{N}$ a megfigyelt hozamok száma, Q3 és Q1 pedig a megfelelő kvartilisek. Bollen és Pool (2009) alapján mind h meghatározásakor, mind a hisztogramok ábrázolásakor figyelmen kívül hagyjuk a kereken 0 hozamokat, mivel azok nem hozamsimítást jelentenek, hanem hiányzó adatokat, vagy a kereskedés hiányát. 
A 0 melleti pozitív és negatív hozamok gyakoriságában megfigyelhető aránytalanságok elemzéséhez a hisztogramokon megfigyelhető eloszlások lefutása mellett alkalmazott statisztikai tesztünk során az egyes 0-körüli osztályközök gyakoriságának a normális eloszláshoz való illeszkedésének mérésére Bollen és Pool (2009), valamint Burgstahler és Dichev (1997) szerinti képletünk:

$$
Z=\frac{\mathrm{f}-\mathrm{Np}}{\sqrt{\mathrm{Np}(1-\mathrm{p})}},
$$

ahol f a megfigyelt gyakoriság az adott osztályközben, $\mathrm{N}$ a megfigyelések száma, $\mathrm{p}$ pedig az adott osztályköznek a várható értéke, amely az elemzésünk során a megfelelő momentumokkal rendelkező normális eloszlás eloszlásfüggvényéből számolt valószínüség.

Az elemzést azzal a két befektetési alappal kezdjük, amelyeket mind a Kételkedési Hányados, mind a Torzítási Ráta kirívóan gyanúsnak ítélt a hozammanipuláció vagy a szuboptimális befektetési döntések potenciális megléte szempontjából, ezek a Citadella Származtatott, valamint a Platina Pí befektetési alapok. Bollen és Pool (2009) elemzését követve mind a Silverman (1986) szerinti osztályszélességgel, mind annak kétszeresével is elkészítettük a hisztogramokat, feketével ábrázolva a 0 -val szomszédos osztályokat az 8. ábrán.

A hisztogram megerősíti a 0-körüli diszkontinuitás meglétét a Citadella Származtatott alap esetében (lásd 8. ábra) és így a feltételezhető hozammanipulációt vagy szuboptimális befektetési döntések miatti torzítást is, mivel mind a kisebb osztályszélesség, mind a kétszeres osztályszélesség esetén is jelentős a 0 melletti pozitív hozamok fölénye: 185-241 valamint 270-377 arányban. A normális eloszláshoz viszonyított tesztstatisztika értéke 12,81 a 0 melletti negatív és 19,12 a 0 melletti pozitív hozamok esetében Silverman (1986) osztályközszélességével számolva, amelyek minden szokásos szignifikancia szinten azt mutatják, hogy mindkét osztályköz esetében a tapasztalt gyakoriság nem követi a normális eloszlást, hanem jelentősen meghaladja azt (kritikus értékek 1,96 és 2,58). Ugyanakkor a 0 melletti pozitív hozamok sokkal inkább meghaladják a normális eloszlást, mint a 0 melletti negatív hozamok, a tesztstatisztika mintegy 1,5-szerese a negatív hozam esetében tapasztalt statisztikáénak. 
2-szeres osztályköz szélességgel számolva a tapasztalt tesztstatisztika értékei 10,3-18,8, azaz az eltérés mintegy 1,8-szeres.
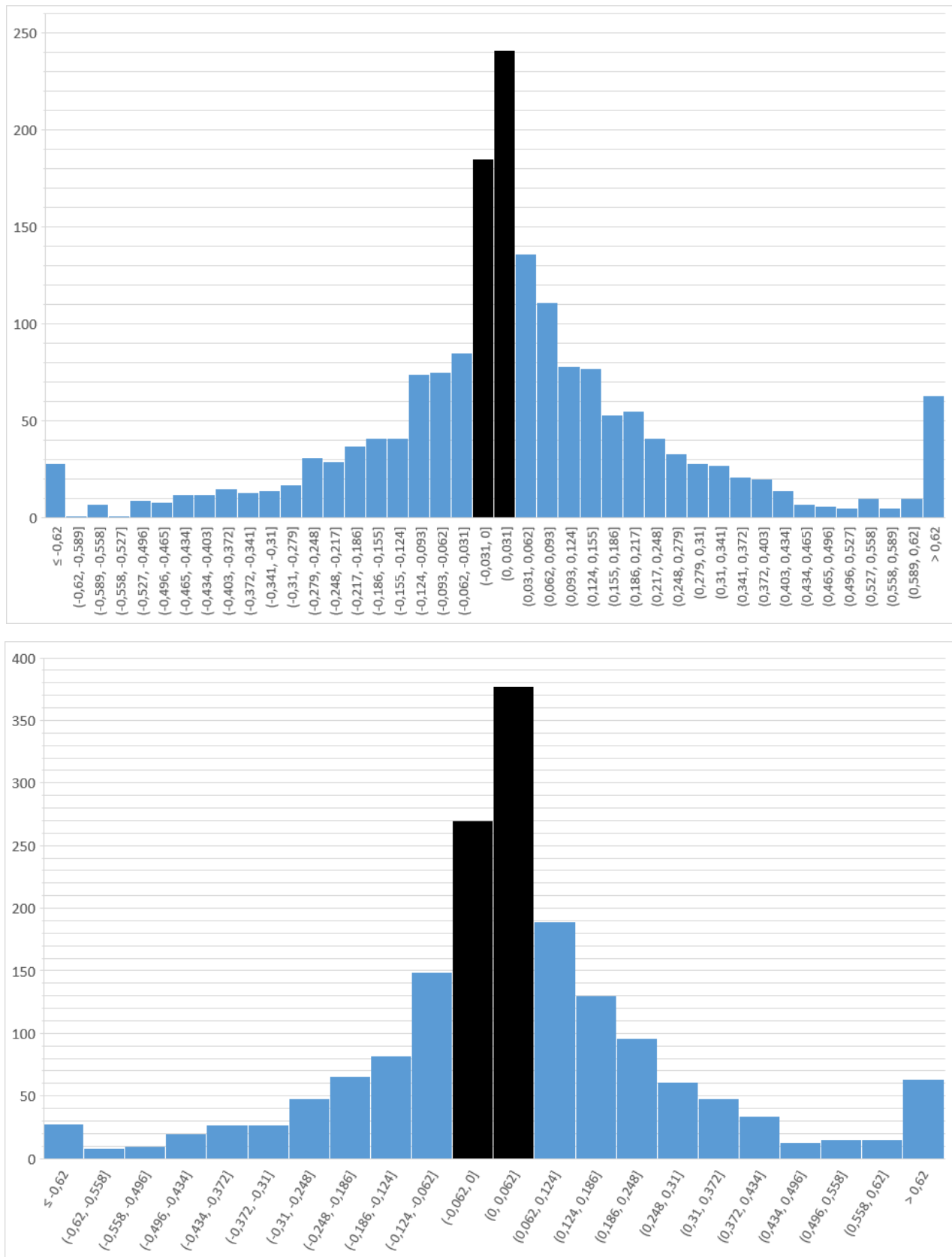

8. ábra: A Citadella Származtatott alap hozamainak 0-körüli diszkontinuitás-elemzése.

Bollen és Pool (2009), Brown et al. (2010) és Burgstahler és Dichev (1997) egyaránt azt találták, hogy a 0 melletti negatív hozamok szignifikáns negatív eltérést mutattak a várható értékükhöz képest, míg a pozitív hozamok pozitív irányban bizonyultak statisztikailag nagyobbnak a várható értéküknél, alátámasztva azt a hipotézist, hogy a 0 
melletti pozitív hozamok gyakorisága feltehetően manipuláció eredményeképpen lett megnövelve a 0 melletti negatív hozamok ellenében. Ezzel szemben az előbbi befektetési alap esetében azt találtuk, hogy a két osztályköz esetén tapasztalt eltérések irányában nincs különbség, ugyanakkor jelentős az eltérés a pozitív hozamok javára. Az eltérések nagyságrendjében megmutatkozó különbség tehát felhasználható számszerű jelzésként a diszkontinuitás meglétének megerösítésére a hisztogram lefutásának megfigyelése mellett.

A további 13 befektetési alapunk hisztogramjainak átvizsgálásakor azokra az esetekre fókuszáltunk, amelyekben a 0 melletti pozitív hozamok gyakorisága jelentősen nagyobb mértékben haladta meg a várható értékét, mint a 0 melletti negatív hozamok gyakorisága a saját várható értékét - hiszen, ha ez nem áll fenn, akkor értelemszerüen nem vádolható azzal a befektetési alap kezelője, hogy igyekezett a 0 körüli pozitív hozamok arányát mesterségesen feljavítani a 0 melletti negatív hozamok rovására. Ezen esetekben a tesztstatisztikák arányában az 1,3 körüli érték bizonyult vízválasztónak, amelynél nagyobb értékek esetén a hisztogram lefutása is a diszkontiunitás meglétét erősítette meg, míg az ennél kisebb értékü tesztstatisztika-hányadosok esetén a hisztogram lefutásában sincs egyértelmü jele a diszkontiunitásnak, így hozamsimításnak vagy szuboptimális befektetési döntések miatti torzításnak.

Az Aegon Ózonmaxx befektetési alap esetében is a potenciális hozammanipuláció vagy szuboptimális befektetési döntések miatti torzítás meglétére találunk nyomokat a hisztogram lefutását tekintve (lásd 9. ábra), mivel itt a 0-körüli közvetlen osztályok rendre 160-201 és 236-384. A tesztstatisztikák értékei pedig 15,2-20,7 és 13,6-27,7, azaz a tesztstatisztikák arányai 1,36 és 2,0. 


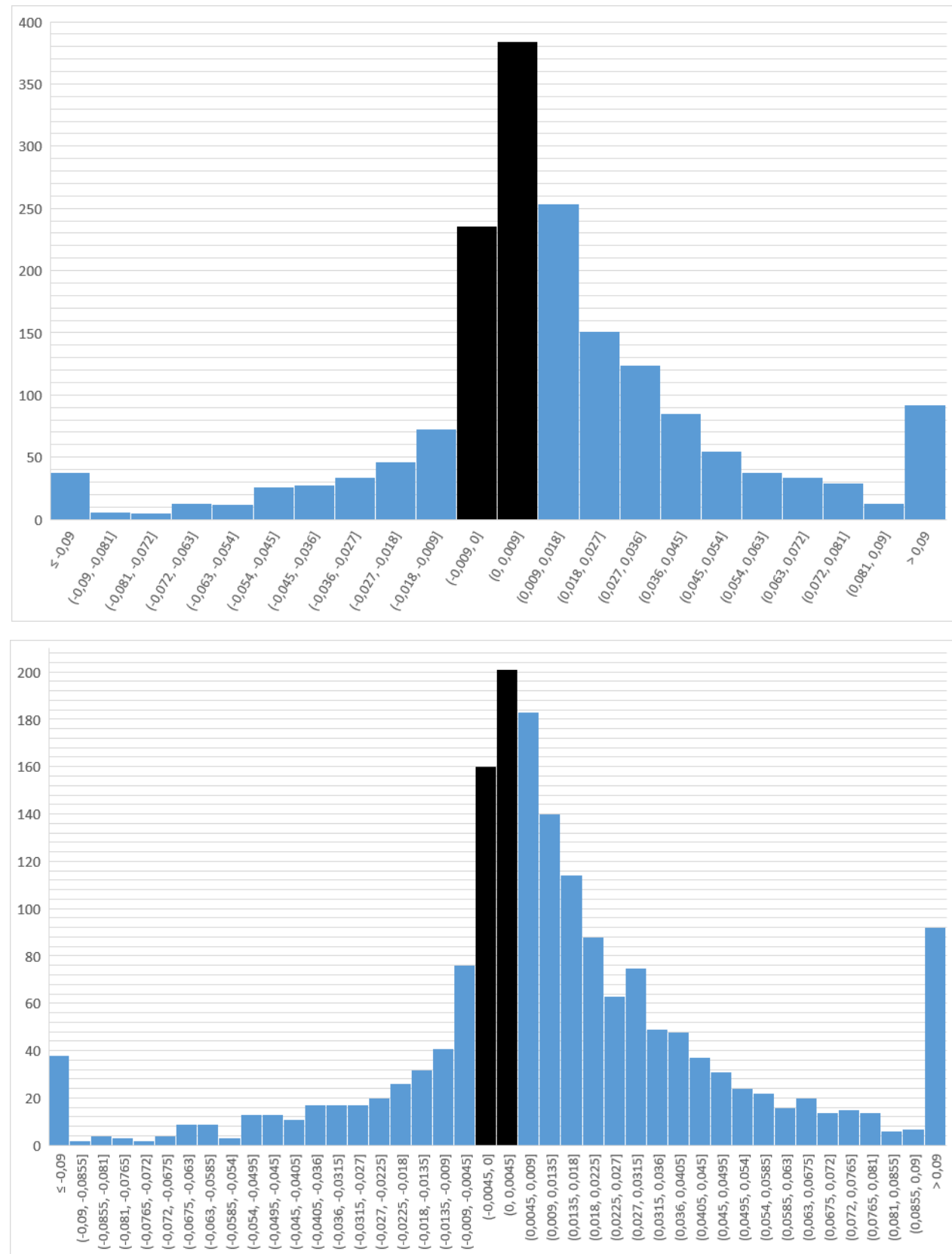

9. ábra: Az Aegon Ózonmaxx alap hozamainak 0-körüli diszkontinuitás-elemzése.

A Torzítási Ráta és a Kételkedési Hányados által a fentiekben kiszürt, a 7. ábra alapján leginkább hozammanipulációval gyanúsítható (4 a Kételkedési Hányados, és 6 a Torzítási Ráta szerint) további befektetési alapok esetében is elvégeztük a fenti diszkontiunitás elemzést a megfelelő osztályszélességü hisztogramok segítségével. A Kételkedési Hányados szerint a legmagasabb értékeket produkáló további alapok, a Platina Pí, Platina Béta és a Platina Alfa befektetési alapok esetében nincs jele 
diszkontinuitásnak, amely ugyanakkor megerősíti azt a már korábban tett megállapítást, hogy valószínüleg nincs szó hozammanipulálásról vagy szuboptimális befektetési döntések miatti torzításnak ezek esetében, mert az értékük jelentősen elmaradt a Brown et al. (2010) által meghatározott 150 körüli értéktől, bár a Torzítási Ráta értékeire vonatkozó Abdulali (2006)-féle átlagszabály szerint már érdemes a hozammanipuláció vagy szuboptimális befektetési döntések miatti torzítás nyomai után kutatni.

A Platina Alfa befektetési alap rendelkezik a legmagasabb, 52,4-es Kételkedési Hányados értékkel, de a Torzítási Ráta értéke 1,15. A 0-körüli hozamok diszkontinuitáselemzése egyértelműen kizárja az esetleges hozammanipuláció vagy szuboptimális befektetési döntések miatti torzítás meglétét, mivel a pozitív hozamok gyakorisága kevésbé haladja meg a normális eloszlásnak megfelelő gyakoriságot, mint a negatív hozamok gyakorisága (lásd 10. ábra): A 0 melletti pozitív hozamok alulmaradnak rendre 188-158 és 290-274, a teszt-statisztika értékei pedig 9,3-5,9 és 7,4-5,3 0,64-es és 0,71-es tesztstatisztika arányt eredményezve. 


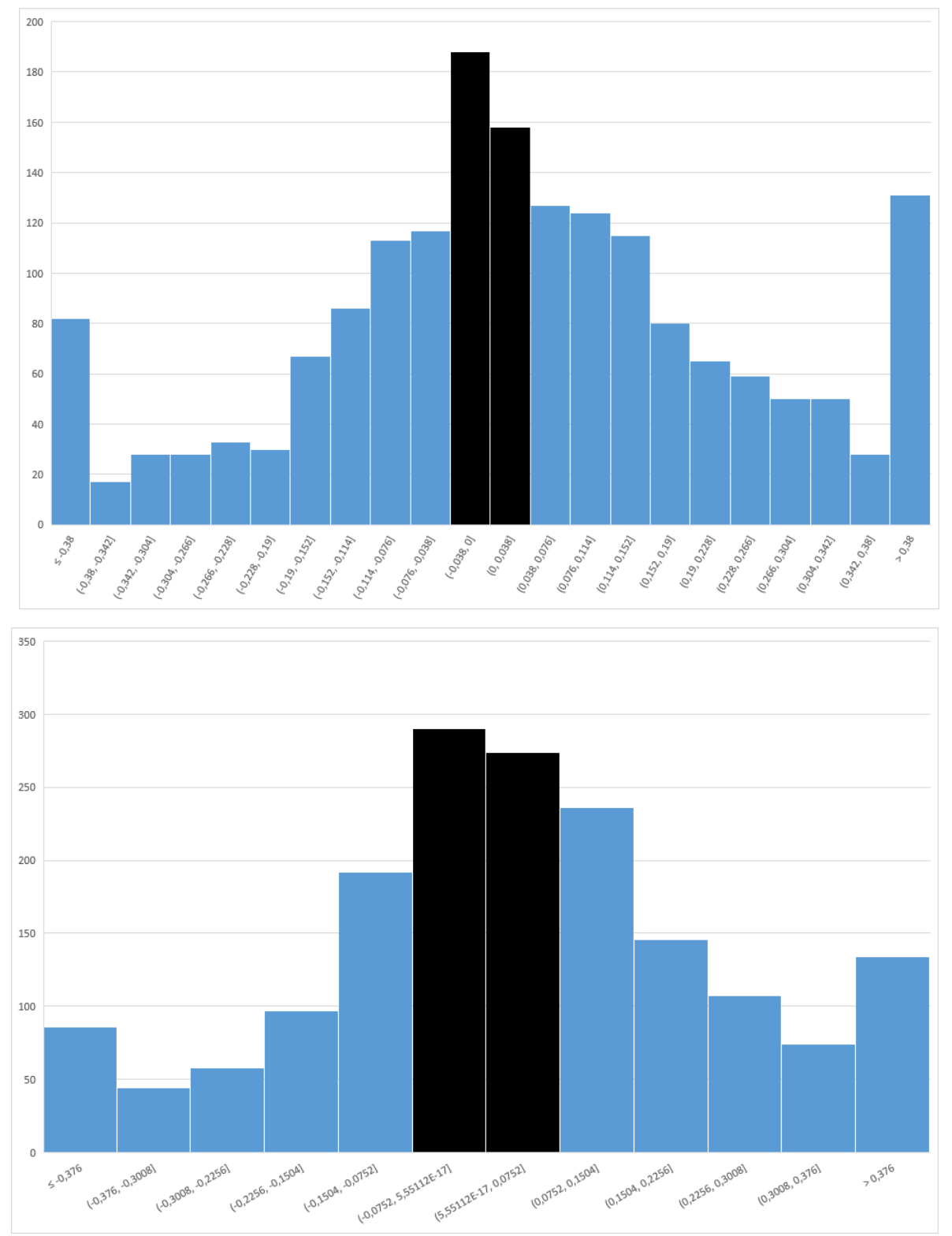

10. ábra: A Platina Béta alap hozamainak 0-körüli diszkontinuitás-elemzése.

A Torzítási Ráta által hozammanipulációval vagy szuboptimális befektetési döntések miatti torzítás leginkább gyanúsított további befektetési alapok, a Raiffeisen Hozam Prémium, Erste DPM, Aegon MoneyMaxx alapok esetében csak az előbbi kettő mutatja a 0-körüli diszkontinuitás jeleit. Az Erste DPM esetében tapasztaljuk a legnagyobb aránytalanságot (lásd 11. ábra) a megfigyelt befektetési alapjaink esetében a 0-körüli kockázatmentes hozammal korrigált hozamokban 143-286, és 220-425 megoszlással, továbbá a tesztstatisztika értékei 13,6-34,2 és 12,7-33,9; amely 2,5-ös, illetve 2,7-es 
tesztstatisztika-arányokat eredményez, így itt a tünik a legegyértelmübb a diszkontinuitás megléte a megfigyelt befektetési alapok közül.

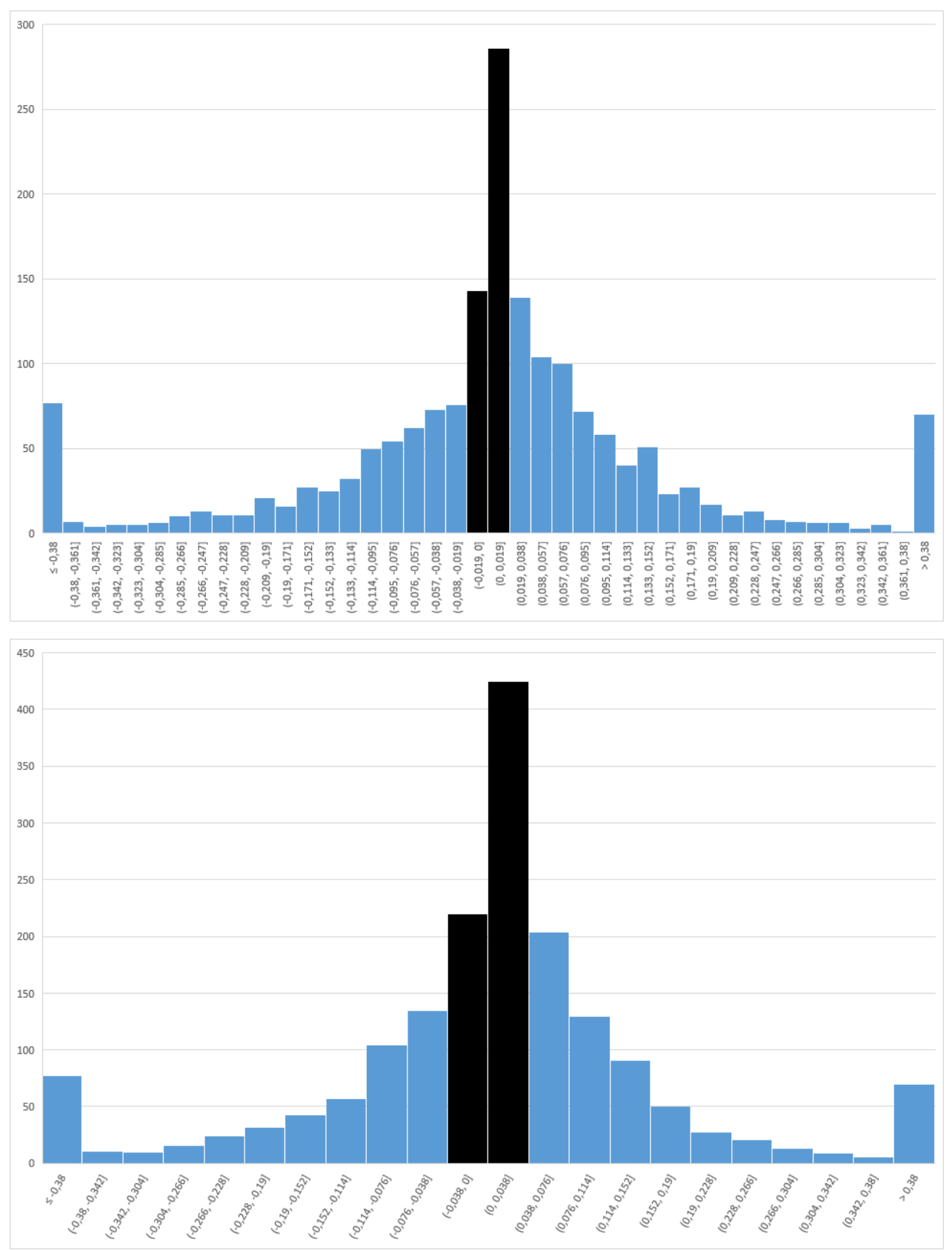

11. ábra: Az Erste DPM alap hozamainak 0-körüli diszkontinuitás-elemzése.

A Raiffeisen Hozam Prémium 153-181 és 257-346-os hozamaránnyal, valamint 1,4-es, valamint 2-es tesztstatisztika aránnyal szintén a 0-körüli diszkontinuitás jeleit hordozza a kockázatmentes hozammal korrigált hozamaiban. Ugyanakkor az Aegon MoneyMaxx 
esetében ki lehet zárni a diszkontinuitás, így a hozammanipuláció vagy szuboptimális befektetési döntések miatti torzítás meglétét.

A Torzítási ráta átlagát meghaladó további 8 befektetési esetében nem találtuk nyomát a 0-körüli diszkontinuitásnak, így a hozammanipulációnak vagy szuboptimális befektetési döntések miatti torzításnak.

Kiegészítésképpen megvizsgáltuk a Generali IPO és Generali Spirit alapokat is, amelyeknek Torzítási Rátái éppen csak kisebbek az átlagnál $(1,1645)$ és nem mutatják a diszkontinuitás jeleit a 0 körüli hozamaikban. Ugyanígy a Concorde Columbus alap sem, amely a Kételkedési Hányados alapján lenne a soron következő az értéke szerint $(30,4)$, ha a Kételkedési Hányados értéke szerint kiterjesztenénk az elemzést a következő legnagyobb értékü alapra - a Torzítási Rátája pedig 1,05-ös értékkel rendelkezik.

\section{A hozammanipuláció szempontjából gyanús befektetési alapok befektetési politikájának elemzése}

A Concorde Citadella a befektetési politikája alapján globális makrogazdasági és fundamentális elemzésekre támaszkodik, használva a technikai elemzés eszköztárát is. A veszteséges pozícióktól való mihamarabbi megszabadulás (stoploss megbízásokkal), és a nyereséges pozíciók megőrzése, növelése fontos alapelv ${ }^{7}$. Az alapkezelővel folytatott interjú alapján az alap kecsegtető befektetési lehetőségek hiányában kockázatmentes kötvényekbe fektet, majd ígéretesnek vélt trendek esetén egy-két nagy trend vagy különbözeti (spread) pozíciót nyit viszonylag szük stoploss megbízással kombinálva. Így, ha a pozíció rosszul sül el és kiüti a stop-loss megbízást kis veszteséggel zárja a pozíciót és újra kockázatmentes befektetésbe allokálva az alap vagyonát várja a következő kínálkozó lehetőséget. Ha pedig a megfelelő irányba mozdul el a piac, és az alapkezelő elér egy általa elég magasnak ítélt hozamot, akkor lezárhatja a pozíciót ${ }^{8}$.

${ }^{7}$ https://premiumbanking.con.hu/befektetesi-alapok/abszolut-hozamu-alapok/

8 A Concorde/Hold Alapkezelötől Móricz Dániel befektetési alapkezelővel folytatott interjú alapján. 
A fenti stratégiával kapcsolatban akkor merül fel a szuboptimális befektetési döntés lehetősége, ha az alapkezelő az év során elért nyereségét (és az ahhoz kötött bónuszát) „védeni” szándékozik a kockázatmentes hozamba allokálással az év hátralévő részében és nem keres erre az időszakra egy kellően diverzifikált portfóliót, mert a kockázatmentes hozamhoz viszonyítva több, mint valószínü, hogy lettek volna hozzáadott értéket, pozitív kockázattal korrigált hozamot adó befektetések az év hátralévő részében is. Így a Concorde Citadella esetében a kimutatott hozammanipulációt indokoltnak tűnik a dinamikus manipuláció kategóriájába sorolni, és a befektetési politika a fentebb leírtak szerint nem tudatos manipulációra, hanem szuboptimális döntésekre utal a kockázatmentes hozamba menekülés/allokálás időszakaira. Érdekes kérdés, hogy vajon a manipulációjelző módszereink akkor is jeleznének-e szuboptimális befektetési döntések miatti torzítást, ha az alapkezelő változtatna a stratégiáján, és a jövőben a kockázatkerülő időszakokra valamilyen likvid, diverzifikált, de nem teljesen kockázatmentes hozamba allokálná a vagyonát.

Az Aegon Ózonmaxx a befektetési politika alapján vagyona döntő többségét a magyar állam, illetve annak mindenkori hitelminősítésével legalább megegyező vagy jobb besorolású államok, kvázi szuverén vállalatok, nemzeti bankok, illetve szupranacionális intézmények által kibocsátott vagy garantált kötvényekbe fekteti, míg az alap vagyonának kisebb részéböl kockázatos eszközöket - hazai és külföldi részvényeket, részvényindexeket, magasabb kockázatú kötvényeket, devizákat, árupiaci termékeket, és kollektív befektetési értékpapírokat vásárol ${ }^{9}$. Az alapkezelővel folytatott interjú szerint az alap a megfigyelt elemzési időszakban tőkevédett alapként müködött, ami azt jelentette, hogy lényegében kockázatmentes kötvénytípusú befektetéseket tartott, és csak az éves hozamot kockáztatta nyereségesnek tűnő kockázatos pozíciókban, és ezáltal „,bázispontonként” gyüjtötte össze a kockázatmentes hozam feletti többlethozamot. ${ }^{10}$ Így esetében nem tünik indokoltnak, hogy két módszer is hozammanipulációval gyanúsítja meg, mivel a befektetési stratégiája magyarázattal szolgál a gyanús hozameloszlására.

Az Aegon Moneymaxx alap a befektetési politikája szerint minden pillanatban a lehető legnagyobb hozammal kecsegtető területre összpontosítja befektetéseit: szerepelhetnek

9 https://www.aegonalapkezelo.hu/jelentesek-kozlemenyek/alapok-dokumentumai/kiemeltbefektetoi-informaciok/

${ }^{10}$ Az Aegon Alapkezelőtől Lancsák András befektetési alapkezelővel folytatott interjú alapján. 
mind magyar, mind nemzetközi pénz- és tőkepiaci eszközök, és ezeken belül az alapkezelő dinamikus portfólió-allokációval mozoghat a lehető legnagyobb hozam elérése érdekében. Az alapban a kockázatos eszközök aránya elméletileg 0-100\% között változhat, az elmúlt években azonban ez az arány nem emelkedett 30-40\% fölé ${ }^{11}$. Az alapkezelővel folytatott interjú szerint az Aegon Monyemaxx alap ugyanakkor szemben a Concorde Citadella alappal, ami egy-kát nagy pozíciót vesz fel, sok kicsi kockázatos pozíciót nyit, amiket külön-külön $\mathrm{kezel}^{12}$. Így befektetési politikája sokkal diverzifikáltabb, és inkább csak az év vége felé fordulhat elő teljes kockázatkerülés. Így érthető, hogy a kockázatmentes és a kockázatos pozíciók közötti dinamikus allokációk ellenére (amiben pozíciónként hasonlít a Concorde Citadella alaphoz), miért csak a Torzítási Ráta találja gyanúsnak, de a diszkontiunitás-elemzés már nem.

Az Erste DPM befektetési politikája szerint az alap célja, hogy a globális részvénypiacok hozamával versenyképes teljesítményt biztosítson a befektetőknek. Az alap alapok alapjaként müködik, azaz aktív befektetési politika alkalmazásával a gazdasági ciklusoknak, illetve a tőkepiacok pillanatnyi állapotának megfelelően tőkéjét szabadon allokálja különböző részvényalapok (globális alapok mellett, régiókat lefedő részvényalapok, iparági szektorokat és befektetési stílusokat - value, growth - lefedő részvényalapok) között. Az Erste DPM befektetési politikája alapján tehát a dinamikus allokációt elsősorban a különböző részvénypiacokat lefedő befektetési alapok között hajtja végre, így esetében mindezek alapján nem lehet azzal vádolni az alapkezelőt, hogy elszalaszt potenciális befektetési lehetőségeket, mivel nem kockázatmentes befektetésekbe menekül ${ }^{13}$. Az Erste DPM esetében tehát a befektetési politika ismeretében nem tünik alátámaszthatónak, hogy két módszer is hozammanipulációval vádolta.

A Raiffeisen Hozam Prémium alap portfóliójának összetételét elsősorban a deviza- és kamatpiaci kilátások függvényében alakítja ki. Az alap tőkéjét az állampapírokon, egyéb hitelviszonyt megtestesítő értékpapírokon és betéteken felül származtatott eszközökbe

11 https://www.aegonalapkezelo.hu/jelentesek-kozlemenyek/alapok-dokumentumai/kiemeltbefektetoi-informaciok/

${ }^{12}$ Az Aegon Alapkezelőtől Lancsák András befektetési alapkezelővel folytatott interjú alapján. 13 https://www.ersteinvestment.hu/static/befrt/download/KIID_DPM_Globalis_Reszveny_20190717.pdf 
és korlátozott mértékben egyéb kockázatos eszközökbe (részvény, certifikát, stb.) fekteti be. Az alap jelenleg olyan stratégiát követ, melynek célja, hogy 2017. július 03-tól kezdődően az Alap kockáztatott érték módszer szerinti lehetséges legnagyobb vesztesége egy év alatt jó eséllyel ne haladja meg a 11,63\%-ot ${ }^{14}$. A Raiffeisen Hozamprémium az alapkezelővel folytatott interjú alapján kötvénytúlsúlyos alap, ami elsősorban a kockázatmentesnél valamivel kockázatosabb kötvényeket tart és így ezért a kis mértékü többletkockázatért igyekszik begyüjteni a többlethozamot a kockázatmentes hozamhoz viszonyítva ${ }^{15}$. Így esetében a hozammanipuláció gyanúját feltehetően az okozza két módszer alapján is, hogy valóban állandósult felülteljesítést látunk a hozameloszlásában a kockázatmentes hozamhoz viszonyítva. Így esetében sem tünik indokoltnak, hogy két módszer is hozammanipulációval gyanúsítja meg, mivel a befektetési stratégiája magyarázattal szolgál a gyanús hozameloszlására, illetve kötvénytúlsúlyos alapok esetében kevésbé megbízhatóan müködnek a hozameloszlást vizsgáló statisztikai módszerek.

Az Aegon Smartmoney alap különböző elemzési technikák útján kiválasztja azon eszközosztályokat, befektetési alapokat, amelyek a legnagyobb felértékelődési potenciállal bírnak és befektetéseket valósít meg befektetési jegyek, illetve kollektív befektetési papírok vásárlásán keresztül ${ }^{16}$. Hasonlóan az Erste DPM befektetési politikájához a dinamikus allokációt elsősorban a különböző részvénypiacokat lefedő befektetési alapok (elsősorban abszolút hozamú alapok) között hajtja végre ${ }^{17}$. Így esetében mindezek alapján nem lehet azzal vádolni az alapkezelőt, hogy elszalaszt potenciális befektetési lehetőségeket, hiszen szinte sosem allokálja a teljes vagyonát kockázatmentes befektetésekbe menekülés/hozamvédés céljából. Szemben az Erste DPM alappal az Aegon Smartmoney esetében a Diszkontiunitás-elemzés nem erősíti meg a hozammanipuláció meglétét.

A Platina Pi alap fundamentális elemzésekre támaszkodva, de a technikai időzítést is figyelembe véve ún. bottom-up elemzés során vonzó befektetési lehetőségek esetén megvizsgálja a középtávú makrogazdasági környezetet (top-down módszer). Ha a két

\footnotetext{
${ }^{14}$ https://alapok.raiffeisen.hu/alapok/hozam-premium

${ }_{15}$ A Raiffeisen Alapkezelőtől Szakál Gábor befektetési alapkezelővel folytatott interjú alapján.

${ }^{16} \mathrm{https}: / /$ www.aegonalapkezelo.hu/wp-content/uploads/2019/06/sm-a-2019.pdf

17 Az Aegon Alapkezelőtől Lancsák András befektetési alapkezelővel folytatott interjú alapján. 
szemlélet eredménye egy irányba mutat, a kiválasztott pozíciót 2-3 lépésben valósítja meg az alap. Ha viszont az alapkezelő nem lát megfelelő lehetőséget magasabb kockázatú instrumentumokban, akkor alacsony kockázatú eszközökbe fekteti az Alap tőkéjét, egészen addig, amíg jó vételi vagy eladási lehetőségek nem adódnak ${ }^{18}$. A befektetési politika alapján tehát a Platina Pí alap hasonló dinamikus allokációs stratégiát alkalmaz a kockázatmentes és kockázatos eszközök között, mint a Concorde Citadella ${ }^{19}$, de az Aegon Moneymaxx-hoz hasonlóan ez az alap is kisebb és ezáltal diverzifikáltabb pozíciókat vesz fel a Concorde Citadellánál és az Aegon Moneymaxx-hoz hasonlóan ezen alap esetében sem erősítette meg a hozammanipuláció meglétét a Diszkontiunitáselemzés.

\section{Összegzés a hozammanipuláció nyomairól és a különböző jelző módszerekről}

Összegezve az elemzett 31 befektetési alapból álló mintán a Kételkedési Hányados 4 alap esetén jelezte a hozamsimítás gyanúját a csoportátlagtól való eltéréssel és ebből 1szer mutatta a Diszkontiunitás-elemzés is a hozammanipuláció valószínű meglétét, amelyet a befektetési politikák és a befektetési alapkezelőkkel folytatott interjúk alapján is be lehet sorolni a feltehetően időszakonként előforduló szuboptimálisnak tekinthető befektetési stratégiák közé a Concorde Citadella alapjának esetében.

A Torzítási Ráta esetén a mediánt meghaladó 10 alapból 4-szer kapott megerősítést a Diszkontiunitás-elemzés alapján is. Ezen 4 alap közül az Aegon Ózonmaxx tőkevédett kötvénytúlsúlyos alap, míg a Raiffeisen Hozamprémium kötvénytúlsúlyos alap, így esetükben a Torzítási Ráta és a Diszkontinuitás-elemzés kevésbé megbízható és a befektetési politikájuk alapján nem tủnik megalapozottnak sem a hozammanipuláció, sem a szuboptimális-döntések gyanúja. Az Erste DPM alapok alapjaként müködik, így esetében is valószínütlen bármilyen típusú manipuláció a befektetési politika ismeretében. A Concorde Citadella alap esetében a befektetési politika alapján jogosnak tünik az időszakonként előforduló szuboptimálisnak tekinthető befektetési stratégiák meglétének a feltételezése.

\section{${ }^{18}$ https://www.erstemarket.hu/befektetesi_alapok/alap/HU0000709969} alapján.

19 A Concorde/Hold Alapkezelőtől Móricz Dániel befektetési alapkezelővel folytatott interjú 
A Torzítási Ráta összességében a hozamsimítás megbízhatóbb jelzőjének tünik, mint a Kételkedési Hányados, mivel eredményeit több módszer is megerősíti. Ugyanakkor figyelembe kell vennünk, hogy a Kételkedési Hányadost pusztán a csoporthoz viszonyítva kirívóan eltérő értékkel bíró befektetési alapok azonosításán keresztül lehetett használni a mintán, mivel a 150-es kritikus értéket egyik befektetési alap sem érte el.

Érdemes megjegyezni, hogy a befektetési politikák ismeretében csak egy alap esetében lehetett megalapozottnak tekinteni az akár több módszer által adott párhuzamos gyanús jelzéseket, míg a többi esetben a befektetési politika ismeretében kétségbe lehetett vonni azok megbízhatóságát. Mindössze a Concorde Citadella alap esetében találunk egybehangzó jelzéseket a Kételkedési Hányados, a Torzítási Ráta és a Diszkontinuitáselemzés, valamint a befektetési politika elemzése által.

Fontos tényező még, hogy az elemzés viszonylag kis mintán készült, így nem tekinthetjük általánosan bizonyítottnak, hogy ez az eltérés nagyobb mintákon is azonos arányban mutatkozna meg a két mutató között. Továbbá azt is érdemes figyelembe vennünk, hogy a Kételkedési Hányados az implikált kockázatelutasítást méri és kapcsolatot teremt a hozamok és a vállalt kockázat között az MBTM-en keresztül, míg a Torzítási Ráta csak a hozamok eloszlását elemzi.

\subsubsection{Az MBTM és a Kételkedési Hányados Ingersoll et al. (2007) - és Brown et al. (2010)-féle értékeinek és rangsorolásának összevetése}

Ebben a fejezetben összehasonlítjuk az Ingersoll et al. - és a Brown et al. (2010)-féle MBTM értékeit és rangsorolását. Az Ingersoll et al. (2007) - és a Brown et al. (2010)féle képlettel számolva nagyon hasonló eredményeket kapunk az MBTM-re mind a mutató értékét, mind a rangsort tekintve. Ez számszerüsítve azt jelenti, hogy a korreláció 1 az MBTM értékeit tekintve 2-es kockázatelutasítási együttható mellett, míg 3-as és 4es paraméter esetén is 0,9999 körüli. A rangkorreláció pedig 2-es és 4-es kockázatelutasítási együttható mellett is 1-es értéket vesz fel, teljes egyezést mutatva, míg 3-as együttható mellett a rangkorreláció értéke 0,9996, szinte teljes egyezést mutatva, amely azt jelenti, hogy a vizsgált 31 alapból 30 ugyanazt a rangsorolást kapja 
és mindössze két alap van, amelyek helyet cserélnek egymással a kétféle módszerrel számolva. A 31 alap 3-féle kockázatelutasítási együtthatóval vett MBTM-sorrendjében tehát a 93 esetből mindössze 2-szer találunk eltérést, azaz 97,85\%-os az egyezés a két módszer esetén.

Az MBTM értékeinek százalékban mért eltérései általában 1\% alatt maradnak a két számítási módszer szerint (lásd 18. táblázat). Az OTP EMDA alapnál 4-es kockázatelutasítás esetén 2,34\%-os eltérést is lehet látni, ami az egyik legnagyobb \%-os eltérést jelenti, ám nem okoz sorrendbeli változást a rangsorban. Ennek egyrészt az az oka, hogy 0-hoz nagyon közel eső MBTM értékeket (Ingersoll et al. (2007) -0,0105, Brown et al. (2010) -0,0108) látunk, így az egyébként abszolút értékben relatíve kis változás $(+0,0002)$ a kétféle számítási módszer között nagy százalékos változást jelent. A másik magyarázata annak, hogy miért nem történik sorrendbeli változás az az, hogy ehhez az egyébként abszolút értékben relatíve kis változáshoz viszonyítva a rangsorban rákövetkező befektetési alapnak az MBTM értéke kellően nagy távolságra van.

Az OTP Supra alap lóg ki a sorból és cserél helyet a Concorde Columbus alappal 3-as kockázatelutasítási együttható mellett az Ingersoll et al. (2007) -féle képletről Brown et al. (2010) -féle képletre váltva. Amíg a Concorde Columbus értékei a két módszerrel 6 tizedesjegyig megegyeznek minden kockázatelutasítási együtthatóra, addig az OTP Supra esetében 3-as kockázatelutasítási együttható mellett 3,4\%-os növekedést tapasztalunk az MBTM értékében a Brown et al.-módszer szerint, amely abszolút értékben is a legnagyobb tapasztalt különbség (0,0013). 4-es kockázatelutasítási együttható mellett 0,003-mal és 13,4\%-kal magasabb a Brown et al.(2010)-féle eredmény. Az OTP Supra alapnál tapasztalt sorrendet befolyásoló értékváltozást az MBTM-ben az magyarázza, hogy míg ennek az alapnak a hozama a második legnagyobb, a hozamainak szórása pedig a negyedik legnagyobb, az eredmények alapján az MBTM-nek a Brown et al. (2010)-féle lineáris közelítése kevésbé bünteti a kockázatot az Ingersoll et al. (2007)-féle számításhoz viszonyítva. A sorrendcserét a két alap között továbbá az is magyarázza, hogy 3-as kockázatelutasítási együttható mellett a két módszer viszonylag nagy abszolút értékkel tér el egymástól és ehhez viszonyítva relatíve kicsi a különbség a két alap MBTM értékei között.

Összegezve tehát a 2-es és 4-es kockázatelutasítási együttható esetében a sorrend megegyezik mind a két módszerrel számolva mind a 31 alap esetében. Egyedül 3-as 
kockázatelutasítási együttható mellett találunk eltérést, amikor is a vizsgált 31 alapból 29 ugyanazt a rangsorolást kapja és mindössze két alap van, amelyek helyet cserélnek egymással a kétféle képlettel számolva. Ezt egyrészt az okozza, hogy 3-as kockázatelutasítási együttható mellett mindkét módszerrel számolva relatíve kicsi a különbség a két alap MBTM értékei között. Másrészt az érintett két alap közül az egyiknek a hozama a második legnagyobb, a hozamainak szórása pedig a negyedik legnagyobb, míg a másik alapnak mind a két értéke átlagosnak mondható és az eredmények azt bizonyítják, hogy az MBTM-nek a Brown et al. (2010)-féle lineáris közelítése kevésbé bünteti a kockázatot az Ingersoll et al. (2007)-féle számításhoz viszonyítva. 


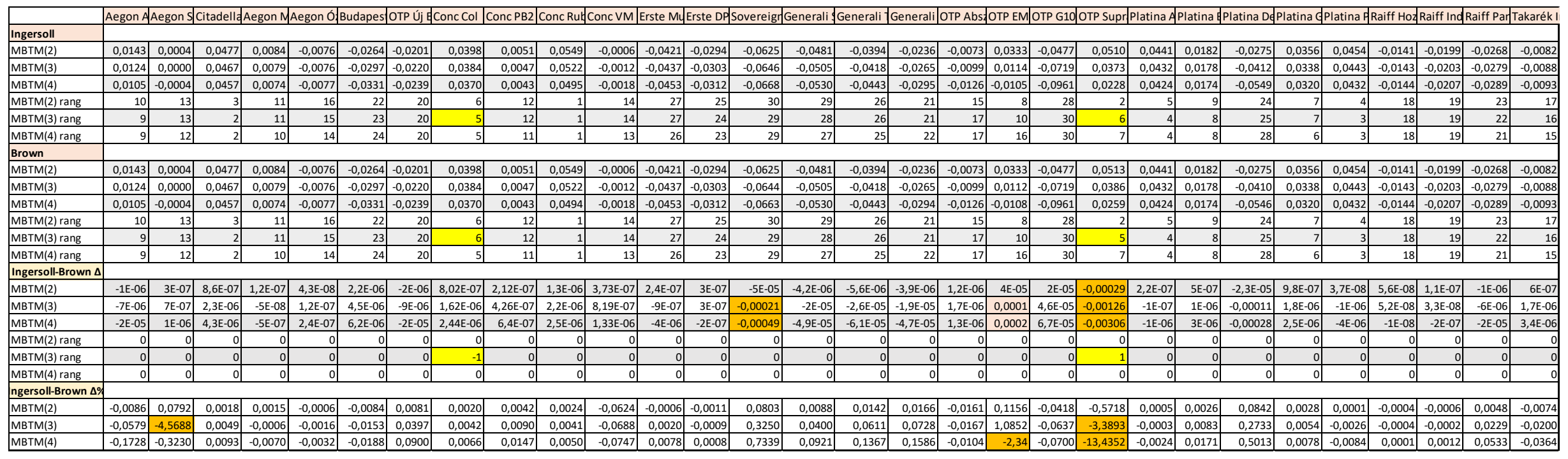

18. táblázat: Az Ingersoll et al. (2007)- és a Brown et al. (2010)-féle MBTM értékeinek és rangsorolásának összevetése. 
A Brown et al. (2010) által használt közelítés (16) szerint a Kételkedési Hányados kiszámítható a többlethozam átlagának és a többlethozam mintából számított szórásnégyzetének arányaként:

$$
\text { Kételkedési Hányados }=\mathrm{DR} \approx \frac{2 \bar{x}}{\left(s_{x}^{*}\right)^{2}}+1 .
$$

A Kételkedési Hányados meghatározható Brown et al. (2010) (16) alapján a különböző kockázatelutasítási együtthatóval számított MBTM értékek egymáshoz viszonyításával is, az implikált kockázatelutasítási együtthatót becsülve. Ha az Ingersoll et al. (2007) által definiált MBTM (Lásd (14)) értékeiből indulunk ki, akkor a képlet az alábbi szerint alakul:

$$
\text { Kételkedési Hányados }=\mathrm{DR}=\frac{\widehat{\Theta}_{\text {Ingersoll }}(2)}{\widehat{\Theta}_{\text {Ingersoll }}(2)-\widehat{\Theta}_{\text {Ingersoll }}(3)}+2 \text {. }
$$

Ha a Brown et al. (2010) által definiált MBTM (Lásd (15)) értékiéiből indulunk ki, akkor a képlet az alábbiak szerint módosul:

$$
\text { Kételkedési Hányados }=\mathrm{DR}=\frac{\widehat{\Theta}_{B r o w n}(2)}{\widehat{\Theta}_{B r o w n}(2)-\widehat{\Theta}_{B r o w n}(3)}+2 .
$$

A Brown et al. (2010) MBTM-alapú képletből (22), valamint a Brown et al. (2010)-féle közelítésből (20) számolva lényegében teljes egyezést kapunk a Kételkedési Hányados értékére (tizenhárom tizedesjegyig), és ennek megfelelően a számított sorrend is teljesen megegyezik, míg a rangkorreláció és korreláció is teljes egyezést mutatva 1-es értéket vesz fel. Az Ingersoll et al. (2007) - és Brown et al. (2010) -alapú MBTM-ből (illetve a Brown et al. (2010)-féle közelítésből) számolva nagyon hasonló értékeket kapunk eredményül, a korreláció 0,9999 és a rangkorreláció 0,9996. A vizsgált 31 befektetési alapból 29 esetében, azaz az alapok 93,5\%-nál a Kételkedési Hányados rangsorában teljes egyezést találunk mindhárom módon történő számítással.

A Kételkedési Hányados Ingersoll et al. (2007) és Brown et al. (2010) -alapú (MBTM, illetve Brown-féle közelítéssel számolt) értékeiben lényeges különbséget a következő alapoknál találunk: Platina Delta, OTP G10, OTP Supra, valamint a Sovereign PB Származtatott alap (lásd 19. táblázat). Ezek közül csak az utóbbi esetében okoz rangsorbeli változást is az értékbeli különbség. Előbbiek esetében a relatíve kis abszolút értékủ változás azzal párosul, hogy a sorban rákövetkező Kételkedési Hányados kellően nagy értékbeli távolságra van ahhoz, hogy ne jöjjön létre sorrendcsere a relatíve magas \%-os változás ellenére sem (lásd pl. a Platina Deltánál tapasztalt 0,0116-os abszolút értékü változást és a hozzá tartozó 72,3\%-os értéket). A Sovereign PB Származtatott alap viszont 1 hellyel került hátrébb a Brown et al. (2010)-féle sorrendben az Ingersoll et al. (2007)-féle sorrendhez viszonyítva úgy, hogy az őt megelőző Erste DPM értékei alig módosultak. Azaz a sorrendben tapasztalt változást végeredményben a 
Sovereign PB Származtatott Alapnál tapasztalt jelentős értékcsökkenés $(-8,87 \%)$ és az idézi elő, hogy a sorban őt követő alap ehhez viszonyítva kellően közeli Kételkedési Hányados értékkel rendelkezik a sorrendcseréhez. Ennél az alapnál tapasztalható a harmadik legnagyobb MBTM-beli abszolút értékü, és az ötödik legnagyobb százalékos változás 4-es kockázatelutasítási együttható esetén az Ingersoll et al. (2007)-féle verzióhoz képest Brown et al. (2010) alapon (0,7339\%), és a tapasztaltak szerint a Kételkedési Hányados értékeibe ez az MBTM-beli eltérés felnagyítva öröklödött tovább $(8,87 \%)$.

Összegezve az Ingersoll et al. (2007) - és Brown et al. (2010) -alapú MBTM-ből számolva nagyon hasonló értékeket kapunk eredményül a Kételkedési Hányadosra: A vizsgált 31 befektetési alapból 29 esetében, azaz az alapok 93,5\%-nak a rangsorában teljes egyezést találunk mindhárom módon történő számítással. Az eltérést az okozza, hogy az egyik alap esetében jelentős értékcsökkenés figyelhető meg az Ingersol et al. (2007) és Brown et al. (2010) alapú megközelítések között, és az őt követő alap Kételkedési Hányados értéke is viszonylag közel esik, miközben annak értéke nem módosul érdemben. A tapasztaltak szerint a Kételkedési Hányados értékeibe ez az MBTM-beli eltérés felnagyítva öröklődött tovább. 


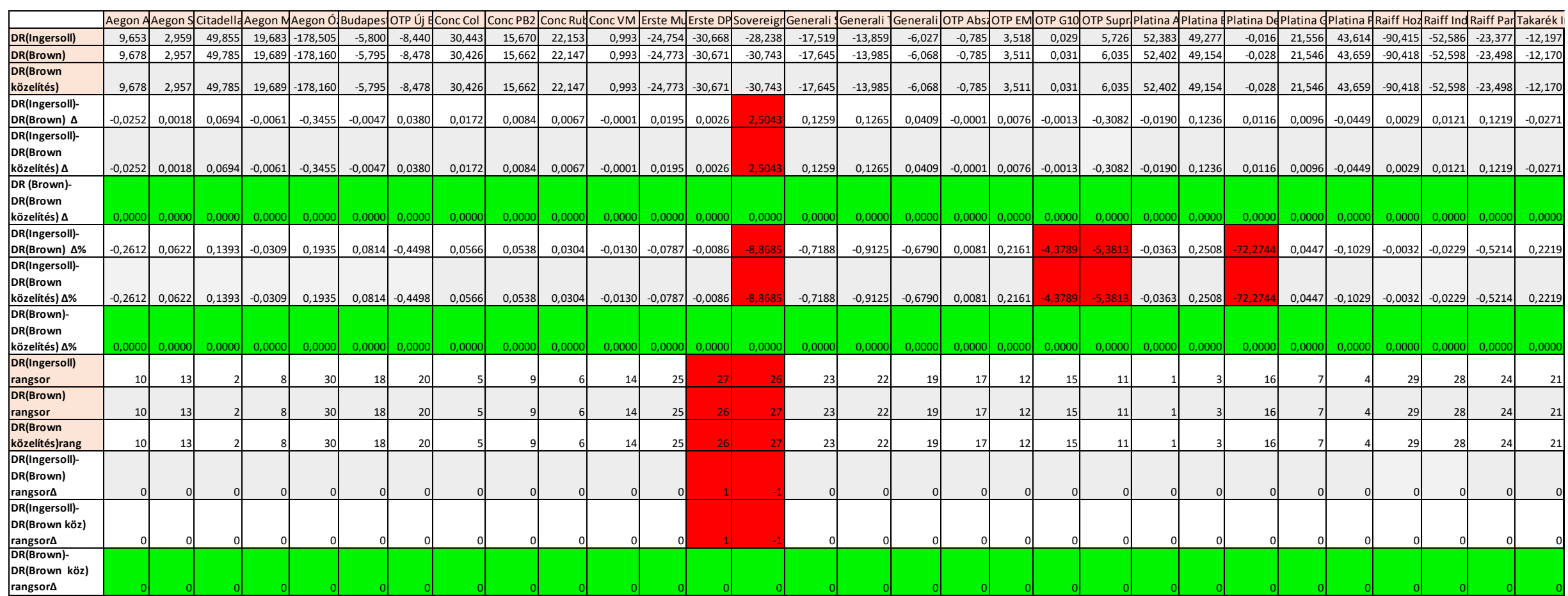

19. táblázat: Kételkedési Hányados értékeinek összehasonlítása Ingersoll et al. (2007) és Brown et al. (2010)-alapú MBTM értékekből számítva, valamint a Brown et al. (2010)-féle közelítést használva. 


\subsubsection{Az Ingersoll et al. (2007) - és Brown et al. (2010)-féle számítási módszer összevetése a gyakorlati használhatóság és a kivitelezés összetettsége alapján, javaslat az alkalmazandó módszerre}

A számításokat elvégezve a 31 magyar abszolút hozamú befektetési alap esetében betekintést nyertünk az alkalmazhatóság, és a kivitelezés nehézsége tekintetében, illetve az egyes módszerek közötti különbségekre vonatkozóan gyakorlati szempontból is, és ezeket foglaljuk össze ebben a fejezetben.

A két módszer között az MBTM-számításában nehézség és a szükséges számítási lépések számát, futási idejét tekintve nincs lényeges különbség. Míg az Ingersoll et al. (2007)-féle képlet a kockázattal korrigált többlethozamok időszaki átlagát veszi, majd korrigálja logaritmussal és a kockázatelutasítási együtthatóval, addig a Brown et al. (2010)-féle módszer az egyszerü többlethozamok időszaki átlagának és szórásnégyzetének különbségeként számol, ahol a szórásnégyzet együtthatójaként jelenik meg a kockázatelutasítási együttható. A Brown et al. (2010)-féle megközelítés így tehát számol egy többlet lépéssel, a többlethozamok szórásnégyzetének kiszámításakor, amely ugyanakkor segít jobban megérteni az MBTM felépítési logikáját, a kockázat számszerüsítése által. Mivel a Brown et al. (2010) által definiált MBTM egy lineáris közelítése a pontosabb Ingersoll et al. (2007)-féle MBTM-nek, és a számításaink szerint előfordul sorrendet is befolyásoló különbség a két módszer között, ezért az Ingersoll et al. (2007)-féle módszert tartjuk a használandó módszernek az MBTM számítás tekintetében. A Brown et al. (2010)-féle MBTM számítását vagy a számításához szükséges lépések elvégzését akkor tartjuk észszerünek, ha az összefüggések jobb megértéséhez a többlethozam átlagára és szórására is kíváncsiak vagyunk az elemzésünk során.

A Kételkedési Hányados kiszámítása mind a Ingersoll et al. (2007), mind a Brown et al. (2010) alapú MBTM értékeinek felhasználásával (továbbá a Brown et al. (2010)-féle Kételkedési Hányados közelítése) ugyanolyan lépéseket foglal magába, így azonos erőfeszítéssel jár. Szem elött tartva a Brown et al. -féle MBTM képlet lineáris közelítésből fakadó tapasztalt pontatlanságait, megállapíthatjuk újításként, hogy a Kételkedési Hányadost az Ingersoll et al. (2007)-féle MBTM-ből számítva pontosabb eredményeket kapunk, így ennek alkalmazását javasoljuk a Brown et al. (2010) helyett. 


\section{3. ÖSSZEFOGLALÓ}

A disszertációban az irodalmi és módszertani összefoglalóban (1. fejezet) bemutattuk első vizsgált témánkhoz, a vállalati jelentéseket övező árfolyamreakciók vizsgálatához kapcsolódóan a piaci hatékonyság, illetve kritikáinak szakirodalmát, továbbá a piaci hatékonyság teszteléséhez használható eszköztárat, az eseményelemzés módszertanát. Szintén a szakirodalmi összefoglalóban mutattuk be a második vizsgált témánk, a befektetési alapok jelentései kapcsán megfigyelhető teljesítménymanipulálás kimutatásához kapcsolódóan a teljesítményértékelés mutatószámainak a fejlődését, továbbá a teljesítménymanipulálás kiküszöbölésére kialakított mutatószámokat, a belőlük képzett manipulációjelző mutatószámot, valamint az alternatív manipulációjelző mutatószámokat és technikákat.

A saját számításainkat összefoglaló 2. fejezetben elsőként a tőzsdei vállalatok negyedéves jelentéseinek árfolyamhatásai körül megfigyelhető árfolyamhatásokat elemeztük, amelynek során a piaci hatékonyság erősségét vizsgáltuk a negyedéves jelentések közzététele körül megfigyelhető abnormális hozamok jelenlétének a mérése által. Ehhez az S\&P 500 és az S\&P 500 IT indexek 45-45 legnagyobb tagjának (amelyekre hiánytalanul rendelkeztünk a szükséges adatokkal) 16 negyedéves jelentéséből álló, 720-720 elemű mintáit elemeztük. A mintákat további alcsoportokra bontottuk aszerint, hogy az egy részvényre jutó eredményben megfigyelhető meglepetés nagyon jó, jó, semleges, rossz vagy nagyon rossz hírt jelent a piac számára.

Az első vizsgált hipotézünk első állítását elfogadtuk: A vállalatok profitabilitásában jelentkező meglepetés iránya és nagysága határozza meg azt, hogy hogyan módosulnak a részvényárfolyamok a vállalati jelentések hatására. Ugyanakkor eltolódás figyelhető meg az egyes hírcsoportok esetén érzékelt kumulált abnormális hozamok szintjében és irányában a negatív ár-reakciók irányába, mivel szignifikáns pozitív hozam csak a nagyon jó hírek csoportjában jelentkezik, míg a jó hírek csoportjában már nincs 0-tól szignifikánsan különbözö hozam, míg a semleges hírek csoportjában már negatív kumulált abnormális hozamokat látunk, ám a rossz és nagyon rossz hírek csoportjában annak mértéke meghaladja a semleges csoportnál tapasztaltat. 
Az első vizsgált hipotézisünk második állítását viszont elvetjük az új információ hatása a bejelentést követő kereskedési napokon már nem figyelhető meg és nem alakul ki a meglepetés irányának megfelelő trend (sőt az S\&P 500 nagyon jó hírek csoportjában szignifikáns árkorrekciót látunk). Így az elemzés azt támasztja alá, hogy a kiválasztott mintában lévő részvények piaca közepesen hatékony.

A semleges hírek esetében tapasztalt szignifikáns negatív abnormális hozamokra magyarázat lehet, hogy a minta egy gazdasági felívelés ciklusából származik, amikor az elvárásokat „csak” teljesítő vállalati eredményeket is negatívan fogadhatják a piaci szereplők.

A nagyon jó, a nagyon rossz és a semleges hírek csoportjaiban szignifikáns eltérés mutatkozik az S\&P 500 és S\&P 500 IT indexek negyedéves jelentéseket övező kumulált abnormális hozamai között a szokásos szignifikancia szinteken, és az S\&P 500 IT hírcsoportjaiban nagyobb a kumulált abnormális hozamok mértéke a két index közül. A jó, illetve a rossz hírek csoportjában viszont nincs érdemi különbség a tapasztalt abnormális hozamok nagyságában a két index között. A jó hírek csoportjával kapcsolatban ez nem meglepő fejlemény annak tükrében, hogy mindkét esetben 0-tól szignifikánsan nem eltérő hozamokat láttunk az elemzés korábbi részében ebben a hírcsoportban, illetve, ha figyelembe vesszük, hogy a negatív árreakciók irányába történő eltolódás miatt ez a hírcsoport számít az origónak a hírcsoportok között. Az eredmények alapján összességében elfogadjuk a második hipotézist arról, hogy a technológiai szektorban erőteljesebb a meglepetés hatása az árfolyamokra az általános részvénypiacnál tapasztalthoz viszonyítva.

A második általunk vizsgált piaci kudarc, a befektetési alapkezelök jelentései körül megfigyelhető hozam- és teljesítménymanipulálás vagy szuboptimális befektetési döntések miatti torzítás a hozamokban, amelyek által a befektetési alapkezelő tudatosan vagy tudattalanul képes javítani a klasszikus mutatószámok által kimutatott teljesítményén az értékelésre használt teljesítménymérő mutatószám ismeretében, pedig valójában nincs olyan többletképesség, -tudás, vagy -információ birtokában, amivel valós hozzáadott értéket, többlet kockázattal korrigált hozamot tudna teremteni, és ezáltal növelné a befektetési jegyeit birtokló racionális befektető hasznosságát. Bár a teljesítménymanipulálás az esetek túlnyomó többségében sem nem csalás, sem nem illegális tevékenység, a félrevezető befektetési alapkezelői tevékenység eredményeképpen nem csak az alapkezelői tevékenység válhat szuboptimálissá, hanem a befektetési alapkezelésen keresztül a vállalatokhoz eljuttatott 
források elosztása is, ami végül nagy társadalmi költséggel jár. A teljesítménymanipulálás vagy szuboptimális befektetési döntések nyomainak kimutatásához a Manipulációbiztos Teljesítménymutatókat (MBTM-eket), a belölük képzett manipulációjelző mutatószámot, a Kételkedési Hányadost, illetve további alternatív módszereket és mutatószámokat használtunk, így a Torzítási Rátát, és Diszkontinuitás-elemzést. Az elemzésünk új eredménynek számít, mivel nem ismert példa a hozammanipuláció nyomainak kimutatásra a szakirodalomban magyar befektetési alapok esetén. Számításainkhoz 31 magyar abszolút hozamú alap 7 éves intervallumot lefedő napi árfolyamadatait használtuk fel. Az eredményeink szerint a rangkorrelációk az MBTM és a Sharpe-ráta között a 0,76-0,82 tartományba esnek, ami ugyan magasabb a nemzetközi példák 0,7 körüli tartományánál, de jelez annyi eltérést a klasszikus mutatószámokhoz viszonyítva, amelyet okozhat valamilyen szintű hozammanipuláció vagy hozamsimítás.

Új eredményként összevetettük az MBTM és a Kételkedési Hányados Ingersoll et al. (2007) és a Brown et al. (2010) szerzőcsoport képleteivel számított értékeit és rangsorolását. Bemutattuk, hogy az Ingersoll et al. (2007) és Brown et al. (2010) alapú MBTM és Kételkedési Hányados eredményei között szinte teljes átfedés van, és megvizsgáltuk, hogy a tapasztalt kis számú eltérés mivel magyarázható. Az eredmények azt bizonyítják, hogy az MBTM-nek a Brown et al. (2010)-féle lineáris közelítése kevésbé bünteti a kockázatot az Ingersoll et al. (2010)-féle számításhoz viszonyítva. Az Ingersoll et al. (2007) és Brown et al. (2010)-féle módszer között tapasztalt nagyobb értékbeli változások az MBTM-ben általában felnagyítva öröklődnek tovább a belölük számított Kételkedési Hányadosba. Sorrendbeli változást a két módszer között akkor találunk mind az MBTM mind a Kételkedési Hányados között, ha a tapasztalt változás kellően nagy, és az alapot rangsorban körülvevő alapok értékei pedig kellően közel esnek az alap értékéhez ahhoz, hogy ez az értékbeli változás hatással legyen a sorrendre.

Mivel nincs érdemi különbség az Ingersoll et al. (2007) és a Brown et al. (2010)-féle MBTM kiszámításának nehézségét és a szükséges lépések számát, futási idejét tekintve, és mivel az Ingersoll et al. (2007)-féle MBTM-nek csak lineáris közelítése a Brown et al. (2010)-féle módszer, amely néha sorrendet is befolyásoló módon pontatlan, ezért az MBTM számítását a pontosabb, Ingersoll et al. (2007) szerinti módszerrel ajánljuk végezni. A Brown et al. (2010)féle eszköztárból elemzési célokhoz ugyanakkor előnyös lehet a többlethozam átlagának és szórásának kiszámítása. További új eredményünk, hogy saját számításaink szerint bár a 
Kételkedési Hányadost Brown et al (2010) építette fel, mégis az Ingersoll et al. (2007)-féle MBTM-re épülő verzióját érdemes használni, mivel általa pontosabb eredményeket kapunk, így ennek alkalmazását javasoljuk.

Saját számításainknak további, a szakirodalomhoz hozzájáruló új eredménye az is, hogy a Kételkedési Hányadosnak a szakirodalomban megfigyelt, az alternatív hozammanipulációt kimutató módszerekkel való szoros átfedésével (Brown et al. (2010) alapján 80\%-os egyezés) szemben az elemzett mintánkon felemás eredményeink születtek: Az alternatív módszerek a 31 befektetési alapból 10 esetben jeleztek potenciális anomáliát, azaz valamilyen hozammanipulációt vagy szuboptimális befektetési döntéseket nagy valószínűséggel, míg a Kételkedési Hányados csak 4 befektetési alapot jelölt meg gyanúsnak. Előbbi esetén a Diszkontinuitás-elemzés általi megerősítést a 10-ből 4 esetben találunk, míg a Kételkedési Hányados esetén 4-ből 1 ugyanez az arány.

Összességében tehát az eredményeink szerint a Torzítási Ráta jobb előszürő eszköznek bizonyult a hozammanipuláció részletesebb elemzéséhez (pl. Diszkontinuitás-elemzéssel, a befektetési politika áttekintésével), mint a Kételkedési Hányados. Ugyanakkor figyelembe kell vennünk, hogy a Kételkedési Hányadost pusztán az outlierek azonosításán keresztül lehetett használni az elemzett mintán, mivel a 150-es kritikus értéket egyik befektetési alap sem érte el és az elemzés viszonylag kis mintán készült, így nem tekinthetjük általánosan bizonyítottnak, hogy ez az eltérés nagyobb mintákon is ugyanígy mutatkozna meg.

A befektetési politikák, valamint a befektetési alapkezelőkkel folytatott interjúk alapján csak egy alap, a Concorde Citadella alap esetében lehetett megalapozottnak tekinteni az akár több módszer által adott párhuzamos gyanús jelzéseket, és ezen alapot mind a Kételkedési Hányados, mind a Torzítási Ráta is gyanúsnak jelölte. Ezen alap esetében megalapozottnak tünik az időnként szuboptimális befektetési döntések miatti torzítás megléte a befektetési politika ismeretében.

Új megközelítést alkalmaztunk akkor is, amikor a csoportátlagtól vett kirívó eltérések grafikus ábrázolásának segítségével különítettük el a gyanús befektetési alapokat, mind a Kételkedési Hányados, mind a Torzítási Ráta esetében. Újításként az alábbi protokollt javasoltuk a teljesítménymanipulálás kiszürésére: 1. A 150-nél nagyobb Kételkedési Hányadossal bíró befektetési alapok Diszkontinuitás-elemzése, valamint a Torzítási 
Rátájának figyelembevétele a medián szabály szerint. 2. A Torzítási Ráta és a Kételkedési Hányados értékeinek grafikus ábrázolása a Torzítási Ráta-Kételkedési Hányados térben, majd a csoportátlagtól való eltérés alapján a szélsőségesnek tűnő befektetési alapok hozamainak Diszkontinuitás-elemzése. 3. A mediánnál nagyobb Torzítási Rátával rendelkező befektetési alapok Diszkontinuitás-elemzése. 4. A befektetési politikák áttekintése a mögöttes befektetési döntések megértésére, amelyek megerősíthetik vagy cáfolhatják a szuboptimális döntések potenciális meglétét, illetve gyengíthetik a statisztikai módszerek megbízhatóságát, ha például kötvénytúlsúlyos a befektetési alap összetétele, vagy ha az alap alapok alapjaként müködik és mindig befektetési alapokba allokálja a tőkéjének a túlnyomó többségét. 


\section{IRODALOMJEGYZÉK}

Abdulali A (2006): The Bias Ratio: Measuring the Shape of Fraud. Protégé Partners Quarterly Letter

Acerbi C, Tasche D (2002): On the Coherence of Expected Shortfall. Journal of Banking and Finance 26: 1487-1504

Akerlof G A, Shiller, R J (2011): Animal Spirits. Avagy a lelki tényezők szerepe a gazdaságban és a globális kapitalizmusban. Budapest: Corvina.

Amihud Y (2014): The Pricing of the Illiquidity Factor's Systemic Risk, dOI10.2139/ssrn.2411856

Arrow K J (1971): Essays in theory of risk-bearing. North-Holland, Amsterdam

Ball R, Brown P (1968) An Empirical Evaluation of Accounting Income Numbers. Journal of Accounting Research 6(2): 159-178

Balog D, Bátyi T, Csóka P, Pintér M (2017): Properties and comparison of risk capital allocation methods. European Journal of Operational Research 259(2): 614-625.

Barberis N, Shleifer A, Vishny R (1998): A model of investor sentiment. Journal of Financial Economics 49(3): 307-343

Barberis N, Thaler R (2003): A Survey of Behavioral Finance. In: Constantinides G M, Harris M, Stulz R M, szerk. Handbook of the Economics of Finance: Corporate Finance. Elsevier 1053-1128

Bélyácz I (2011): Cáfolja-e a globális pénzügyi válság a hatékony piac hipotézisét? Jura 17 (1): 7-24

Berlinger E, Horváth F, Vidovics-Dancs Á (2012): Tőkeáttétel-ciklusok. Hitelintézeti Szemle 11(1): 1-23

Berlinger E, Keresztúri J L, Tamásné Vőneki Zs (2018): A müködési kockázatokra ható, országspecifikus tényezők vizsgálata: A sajtószabadság szerepe. In: Dömötör, B.; Keresztúri, J. L., szerk. PRMIA Hungary Chapter Éves Konferenciája, A Magyar kockázatkezelési kutatások legújabb eredményei TANULMÁNYKÖTET. Budapest: Budapesti Corvinus Egyetem, 18-24.

Bernard V L, Thomas J K (1989): Post-Earnings-Announcement Drift: Delayed Price Response or Risk Premium? Journal of Accounting Research 27: 1-36 
Binder J J (1998): The Event Study Methodology Since 1969. Review of Quantitative Finance and Accounting 11(2): 111-137

Bodie Z. Kane A, Marcus A J (2009): Investments. McGraw-Hill.

Boehmer E, Musumeci J, Poulsen A B (1991): Event-study methodology under conditions of event-induced variance. Journal of Financial Economics 30(2): 253-272

Bollen NPB, Pool VK (2008): Conditional Return Smoothing in the Hedge Fund Industry. Journal of Financial and Quantitative Analysis 43:267-298

Bollen NPB, Pool VK (2009): Do Hedge Fund Managers Misreport Returns?Evidence from the Pooled Distribution. Journal of Finance 64:2257-2288

Brealey R A, Myers S C (2011): Modern vállalati pénzügyek. 7 szerk. Budapest: Panem

Brennan M J, Jegadeesh N, Swaminathan B (1993): Investment Analysis and the Adjustment of Stock Prices to Common Information. The Review of Financial Studies 6(4): 799-824.

Brown N C, Wei K D, Wermers R (2013): Analyst recommendations, mutual fund herding, and overreaction in stock prices. Management Science 60(1): 1-20

Brown S, Kang M, In F, Lee G (2010): Resisting the Manipulation of Performance Metrics: An Empirical Analysis of the Manipulation-Proof Performance Measure

Burgstahler D, Dishev I (1997): Earnings management to avoid earnings decreases and losses. Journal of Accounting and Economics 24: 99-126.

Cable J, Holland K (1999): Modelling normal returns in event studies: a model-selection approach and pilot study. The European Journal of Finance 5(4): 331-341

Csóka P, Pintér M (2016): On the impossibility of fair risk allocation. The B.E. Journal of Theoretical Economics, 16 (1): 143-158

Chan L K C, Jegadeesh N, Lakonishok J (1996): Momentum Strategies. The Journal of Finance 51 (5): 1681-1713

Chan L K C, Karceski J, Lakonishok J (2007): Analysts' Conflict of Interest and Biases in Earnings Forecasts. Journal of Financial and Quantitative Analysis 42(4): 893-914

Chordia T, Goyal A, Sadka G, Sadka R (2009): Liquidity and the Post-EarningsAnnouncement Drift. Financial Analysts Journal 65(4): 18-32

Chordia T, Subrahmanyam A, Tong Q (2014): Have capital market anomalies attenuated in the recent era of high liquidity and trading activity? Journal of Accounting and Economics, 58(1): 41-58

Corrado C J (2011): Event studies: A methodology review. Accounting \& Finance, 51(1): $207-234$ 
Daniel K D, Hirshleifer D, Subrahmanyam A (2001): Overconfidence, Arbitrage, and Equilibrium Asset Pricing. The Journal of Finance 56(3): 921-965

Daniel K, Hirshleifer D, Subrahmanyam A (1998): Investor Psychology and Security Market Under- and Overreactions. The Journal of Finance 53(6): 1839-1885

Daniel K, Titman S (1999): Market Efficiency in an Irrational World. Financial Analysts Journal 55(6): 28-40

Danielsson J (2011): Financial Risk Forecasting. The Theory and Practice of Forecasting Market Risk, with Implementation in R and Matlab. Chichester: Wiley

Danielsson J (2013): Global Financial Systems. Stability and Risk. Harlow: Pearson

Danielsson J, Shin H S, Zigrand J-P (2009) Risk Appetite and Endogenous Risk http://www.lse.ac.uk/fmg/researchProgrammes/paulWoolleyCentre/pdf/second\%20Confernc \%20Papers/Zigrand.pdf

De Bondt W F M, Thaler R (1985): Does the Stock Market Overreact? The Journal of Finance 40(3): 793-805

deHaan E, Shevlin T, Thornock J (2015): Market (in) attention and the strategic scheduling and timing of earnings announcements. Journal of Accounting and Economics 60(1): 36-55

Doyle J T, Magilke M J (2015): The Strategic Timing of Management Forecasts $\underline{\text { http://ssrn.com/abstract }=1479867}$

Dyck A, Lins KV, Pomorski L (2013): Does Active Management Pay? New International Evidence. Review of Asset Pricing Studies 3(2):200-228

Fama E F (1970) Efficient Capital Markets: A Review of Theory and Empirical Work. The Journal of Finance 25(2): 383-417

Fama E F (1991): Efficient Capital Markets: II. The Journal of Finance 46(5): 1575-1617

Fama, E F (1998): Market efficiency, long-term returns, and behavioral finance. Journal of Financial Economics 49(3): 283-306

Fama E F, Fisher L, Jensen M C, Roll R (1969): The Adjustment of Stock Prices to New Information. International Economic Review 10(1): 1-21

Fama E F, French K R (1992): The Cross-Section of Expected Stock Returns. The Journal of Finance 47(2): 427-465

Fama E F, French K R (1996): Multifactor Explanations of Asset Pricing Anomalies. The Journal of Finance 51(1): 55-84

Francis J, Lafond R, Olsson P, Schipper K (2007): Information Uncertainty and PostEarnings-Announcement-Drift. Journal of Business Finance \& Accounting 34(3-4): 403-433 
Friend I, Blume M E (1975): The demand for risky assets. American Economic Review 65: 900-922

Foster G, Olsen, C, Shevlin T (1984): Earnings Releases, Anomalies, and the Behavior of Security Returns. The Accounting Review. 59(4): 574-603.

Gandelman N, Hernandez-Murillo, R (2015): Risk Aversion at the Country Level. Review 97 (1): 53-66

Gemmill G, Hwang S, Salmon M (2006): Performance measurement with loss aversion. Journal of Asset Management 7(3-4): 190-207

Gompers P A, Metrick A (2001): Institutional Investors and Equity Prices. The Quarterly Journal of Economics 116(1): 229-259

Gospodinov N, Robotti C (2013): Asset Pricing Theories, Models, and Tests. In: Baker H K, Filbeck G, szerk. Portfolio Theory and Management. Oxford University Press: 46-72

Grossman S J, Stiglitz J E (1980): On the Impossibility of Informationally Efficient Markets. The American Economic Review 70(3): 393-408

Hasanhodzic J, Lo AW (2007): Can Hedge Fund Returns Be Replicated? The Linear Case. Journal of Investment Management 5(2):5-45

Havran D, Lovas A, \& Berezvai Z (2015): Vállalati pénzügy (SPM, SKM): Gondolkodtató és gyakorló feladatok gyüjteménye, Budapest: Befektetések és Vállalati Pénzügyi Tanszék Alapítványa.

Hirshleifer D (2001): Investor psychology and asset pricing. The Journal of Finance, 56(4): 1533-1597

Hirshleifer D, Lim S S., Teoh S H (2009): Driven to Distraction: Extraneous Events and Underreaction to Earnings News. The Journal of Finance 64(5): 2289-2325

Hou K, Peng L, Xiong W (2009): A Tale of Two Anomalies: The Implication of Investor Attention for Price and Earnings Momentum. http://ssrn.com/abstract=976394

Hunyadi L, Vita (2008): Statisztika II. Budapest: Aula

Ingersoll J, Spiegel M, Goetzmann W, Welch I (2007): Portfolio Performance Manipulation and Manipulation-proof Performance Measures. The Review of Financial Studies 20(5):1503-1546

Jegadeesh N, Titman S (1993): Returns to Buying Winners and Selling Losers: Implications for Stock Market Efficiency. The Journal of Finance, 48(1): 65-91

Jensen M (1969): Risk, the pricing of capital assets, and the evaluation of investment portfolios. Journal of Business 42:217-235 
Jensen M C (1968): The Performance of Mutual Funds in the Period 1945-1964. The Journal of Finance 23(2): 389-416

Jorion P (1996): Risk2: Measuring the risk in Value at Risk. Financial Analysts Journal 52(6):47-56

Kahneman D (2013): Gyors és lassú gondolkodás. Budapest: HVG Könyvek

Kahneman D, Riepe M W (1998): Aspects of investor psychology. The Journal of Portfolio Management 24(4): 52-65

Kahneman D, Tversky A (1979): Pospect Theory: An Analysis of Decision Under Risk. Econometrice 47(2): 263-292

Kahneman D, Tversky A (1992): Advances in prospect theory: Cumulative representation of uncertainty. Journal of Risk and Unvcertainity 5(4): 297-323.

Kaushik A, Brinckman DE, Rose CC (2013): Performance Evaluation and Fund Selection Criteria for Mutual Funds over the Period 2000-2011. Accounting and Finance Research 2(3):111-118

Kolari J W, Pynnönen S (2010): Event Study Testing with Cross-sectional Correlation of Abnormal Returns. The Review of Financial Studies 23(11): 3996-4025

Kothari S P, Warner J B (2007): Econometrics of Event Studies. In: Eckbo B E, szerk. Handbook of Corporate Finance. Empirical Corporate Finance. North Holland: 3-36

Kumar A (2009): Hard-to-Value Stocks, Behavioral Biases, and Informed Trading. The Journal of Financial and Quantitative Analysis 44(6): 1375-1401

Kydland F E, Prescott E C (1982): Time to build and aggregate fluctuations. Econometrica 50: 1345-1370

Laffont J-J, Maskin E S (1990): The Efficient Market Hypothesis and Insider Trading on the Stock Market. Journal of Political Economy 98(1): 70-93

Lakonishok J, Lee I (2001): Are Insider Trades Informative?. The Review of Financial Studies 14(1): 79-111

Lakonishok J, Shleifer A, Vishny R W (1994): Contrarian Investment, Extrapolation, and Risk. The Journal of Finance 49(5): 1541-1578

Layard R, Mayraz G, Nickell S (2008): The Marginal Utility of Income. Journal of Public Economics 92(8-9): 1846-57

Lehmann B N (1990): Fads, Martingales, and Market Efficiency. The Quarterly Journal of Economics 105(1): 1-28

Lequeux P, Acar E (1998): A Dynamic Benchmark for Managed Currencies Funds. European Journal of Finance 4(4):311-330 
Lintner J (1965): The valuation of risk assets on the selection of risky investments in stock portfolios and capital budgets. Review of Economics and Statistics 47: 13-37

Lo A W, MacKinlay A C (1990): When are Contrarian Profits Due to Stock Market Overreaction? The Review of Financial Studies 3(2): 175-205

Mallikarjunappa T, Dsouza J J (2014): A Study of Quarterly Earnings Announcement and Stock Price Reactions, The IUP Journal of Applied Finance

MacKinlay A C (1997): Event Studies in Economics and Finance. Journal of Economic Literature 35(1): 13-39

Malkiel B G (2003): The Efficient Market Hypothesis and Its Critics. Journal of Economic Perspect 17(1): 59-82

Malkiel B G (2005): Reflections on the Efficient Market Hypothesis: 30 Years Later. The Financial Review 40(1): 1-9

Mas-Colell A, Whinston MD, Green JR (1995): Microeconomic Theory. Oxford University Press, Oxford

Modigliani F, Modigliani L (1997): Risk- Adjusted Performance. Journal of Portfolio Management 23:45-54

Naffa H (2009): Eszközárazási anomáliák többváltozós modellje. Hitelintézeti Szemle, 8(6): $516-527$

Erdő P, Ormos P, Zibricky D (2011): Non-parametric and semi-parametric asset pricing. Economic Modelling, 28(3): 1150-1162

Pellicer M J A, Rees W P (1999): Regularities in the Equity Price Response to Earnings Announcements in Spain. The European Accounting Review, 8(4): 585-607

Pojarliev M, Levich RM (2008): Do professional currencymanagers beat the benchmark? Financial Analysts Journal 64(5): 18-32

Pojarliev M, Levich RM (2013): Evaluating Absolute Return Managers. Financial Markets and Portfolio Management 28(1): 95-103

Rao S V D N, Sreejith U (2014): Event Study Methodology: A Critical Review. The Macrotheme Review 3(1A): 40-53

Rácz D A (2012): Why Invest in Energy Efficiency? The Example of Lighting, Journal of Environmental Sustainability, Volume II. Edition 1 - DOI: 10.14448/jes.02.0001

Rácz D A (2019a): Abszolút hozamú befektetési alapok teljesítményének értékelése - a teljesítménymanipulálás kimutatása. Közgazdasági Szemle 66(7-8): 824-846 
Rácz D A (2019b): Manipulációbiztos mutatók összehasonlítása magyar adatokon. Hitelintézeti Szemle 18(2): 31-51

Rácz D A, Huszár G (2018) Negyedéves jelentések meglepetéshatása S\&P 500 indexelemekre. Kéziratcikk

Rácz D A, Huszár G (2019): Negyedéves jelentések meglepetéshatása S\&P 500 indexelemekre. Pénzügyi Szemle/Public Finance Quarterly 2019/2: 244-264

Rockafellar R, Uryasev S (2001): Conditional value-at-risk for general loss distributions. Tech. rep., ISE Dept., University of Florida

Russell T, Thaler R (1985): The Relevance of Quasi Rationality in Competitive Markets. The American Economic Review 75(5): 1071-1082

Skinner D J, Sloan R G (2002): Earnings surprises, growth expectations, and stock returns or don't let an earnings torpedo sink your portfolio. Review of Accounting Studies 7: 289-312

Schwager J D (2012a): Market Wizards. Interviews with Top Traders. Hoboken, New Jersey: Wiley

Schwager J D (2012b): Hedge Fund Market Wizards. How Winning Traders Win. Hoboken, New Jersey: Wiley

Serra A P, (2004): Event Study Tests: A Brief Survey. $\underline{\text { http://ssrn.com/abstract }=1066816}$

Sharpe W F (1964): Capital Asset Prices: A Theory of Market Equilibrium under Conditions of Risk. The Journal of Finance 19(3): 425-442

Sharpe W F (1966): Mutual Fund Performance. Journal of Business 39: 119- 138

Shleifer A, Vishny R W, (1997) The Limits of Arbitrage. The Journal of Finance 52(1): $35-55$

Soros G, (2003): The Alchemy of Finance. 3. ed. Hoboken, New Jersey: John Wiley \& Sons

Sortino F A, Price L N (1994): Performance measurement in a downside risk framework. Journal of Investing 3:50-8

Silverman BW (1986): Density Estimation for Statistics and Data Analysis. Chapman and Hall, MA: New York

Sortino F A (2001): From Alpha to Omega. In: Sortino FA, Satchell SE (eds) Managing Downside Risk in Financial Markets, Reed Educational and Professional Publishing Ltd.

Sortino F A, van der Meer R (1991): Downside Risk. Journal of Portfolio Management 17: $27-31$ 
Szpiro G G, Outreville J-F (1988): Relative Risk Aversion Around the World: Further Results, Journal of Banking and Finance, 6 (1): 127-28

Treynor J (1965): How to Rate Management of Investment Funds. Harward Business Review 43:63-75

Treynor J, Black F (1973): How to Use Security Analysis to Improve Portfolio Selection. Journal of Business 46: 66-86

Treynor J, Mazuy K (1966): Can Mutual Funds Outguess the Market? Harvard Business Review 44:131-136

Váradi K, Gyarmati Á, Lublóy Á (2012): Virtuális árhatás a Budapesti Értéktőzsdén. Közgazdasági Szemle 59(5): 508-539

Zhang X F (2006): Information Uncertainty and Stock Returns. The Journal of Finance 41(1): $105-136$

Zawadowski Á (2017): Kezelési költségük határozza-e meg a Magyarországon forgalmazott részvénypiaci befektetési alapok teljesítményét? Közgazdasági Szemle 64(11): 1186-1201

Walter Gy (2002): VaR-limitrendszer melletti hozammaximalizálás: a kaszinóhatás. Közgazdasági Szemle 49 (3): 212-234

Watts R L (1978): Systematic 'Abnormal' Returns after Quarterly Earnings Announcements. Journal of Financial Economics, 6(2 -3): 127-150

Young T W (1991): Calmar ratio: A smoother tool. Futures 20(1): 40 


\section{A TÉMAKÖRREL KAPCSOLATOS SAJÁT PUBLIKÁCIÓK JEGYZÉKE}

\section{Publikációk referált szakmai folyóiratokban (magyar)}

Rácz D A (2019a): Abszolút hozamú befektetési alapok teljesítményének értékelése - a teljesítménymanipulálás kimutatása. Közgazdasági Szemle 66(7-8): 824-846

Rácz D A (2019b): Manipulációbiztos mutatók összehasonlítása magyar adatokon. Hitelintézeti Szemle 18(2): 31-51

Rácz D A - Huszár G (2019): Negyedéves jelentések meglepetéshatása S\&P 500 indexelemekre. Pénzügyi Szemle/Public Finance Quarterly 2019/2: 244-264

\section{Publikációk referált szakmai folyóiratokban (angol)}

Rácz D A (2012): Why Invest in Energy Efficiency? The Example of Lighting, Journal of Environmental Sustainability, Volume II. Edition 1 - DOI: 10.14448/jes.02.0001

Rácz D A (2019b): Comparison of Manipulation-proof Measures on Hungarian Data. Financial and economic review 18(2): 31-51

Rácz D A, Huszár G (2019): The Effects of Earnings Surprises in Quarterly Reports on S\&P 500 Components. Public Finance Quarterly 2019/2: 239-259

\section{Egyéb}

\section{Könyvfejezet}

Csóka P, Rácz D A (2016): Költségegyenértékes a fejlesztések értékelésében In: Fazakas Gergely, Walter György (szerk.) Vállalati pénzügyi esetek és döntések. 184 p. Budapest: Befektetések és Vállalati Pénzügyi Tanszék Alapítványa, 2016. p. 46-47. - ISBN:978-963-12$5887-5$ 


\section{Konferenciakiadványok és előadások (magyar)}

Rácz D A (2013): Energiahatékonysági befektetések pénzügyi hozamainak és kockázatainak elemzése, Torockó, Románia, Mikó Imre Szakkollégium, Pénzügyi Tábor, 2013. április 20 .

Morvay E, Lakatos Zs, Rácz D A (2018): Beszámoló a 8. Pénzügyi piacok likviditása konferenciáról. Hitelintézeti Szemle 17(2): 161-165.

\section{Konferenciakiadványok és előadások (angol)}

Rácz D A (2014): How to Measure the Performance of Active Portfolios - A Literature Review, Annual Financial Market Liquidity Conference Budapest, 2014. november 20-21. Budapest: BCE Befektetések és Vállalati Pénzügy Tanszék, 2014. p. 20. - ISBN:978-963-12$1068-2$

Rácz D A (2015): Tracing the Performance Manipulation of Active Funds, Annual Financial Market Liquidity Conference Budapest, 2015. november 19-20. Budapest: BCE Befektetések és Vállalati Pénzügy Tanszék, 2015. p. 39. - ISBN 978-963-12-4291-1

\section{Mühelytanulmányok}

Rácz D A (2014): Performance Measurement of Active Funds, 4th PhD Student Conference, Corvinus University of Budapest, 2014. December 5.

Rácz D A (2015): Mutual Fund Performance Evaluation, 5th PhD Student Conference, Corvinus University of Budapest, 2015. május 13.

Rácz D A, Huszár G (2018) Negyedéves jelentések meglepetéshatása S\&P 500 indexelemekre. 